Original Article

Received/Accepted Dates

05.11.2021/21.12.2021

DOI: 10.52096/jsrbs.7.14.4
Journal of Social Research and Behavioral Sciences

Sosyal Araştırmalar ve Davranış Bilimleri Dergisi

ISSN:2149-178X

Volume: 7 Issue: 14 Year: 2021

\title{
Bazı İslami Dergiler Örnekleminde Carl Gustav Jung: Nitel Bir Araştırma
}

\author{
Dr. Öğt. Üyesi Beyazıt Yaşar SEYHAN \\ OKÜ İlahiyat Fakültesi Din psikolojisi \\ beyazit.seyhan1@gmail.com \\ ORCID ID: 0000-0001-7404-3976
}

\section{Özet}

Cumhuriyetin ilk kurulduğu dönemde bile (Balaban'ın ifadesi ile) “insanın manevi varlı̆̆ından bahseden ruhiyat(=psikoloji) ilmi” o dönemin yazarları tarafından hep ilgi çekici olmuştur. Özellikle 1940'l1 yıllardan itibaren, Türkiye'de basılan ilmî, ahlakî, dinî ve edebî bazı dergilerde din psikolojisinde meşhur olan Carl Gustav Jung gibi Batılı psikologların görüşleri anlatılmıştır. Bu araştırmada, söz konusu bu dergilerde C. G. Jung'un ve onun görüşlerinin nasıl ele alındığı analiz edilmeye çalışılmıştır. Araştırmada ele alınan dergiler şunlardır: "Sebilürreşad”, "Müslüman Sesi”, "Tevhid”, "Yeni Zemin”, "Yörünge”, "Akademiya”, "Genç", "Kültür Dünyası”, "Aylık” ve "Kur 'ani Hayat”. Araştırmamızda bu incelenen dergilerde Jung'a ve görüşlerine yaklaşım tarzı araştırılmış olup birtakım sonuçlar elde edilmiştir. Buna göre, bazı İslami dergiler Jung'un emsallerinden farklı olduğunu kabul ettikleri için Jung, İslami kesim tarafından kabul edilmiş bir olguya sahiptir”. İslami dergilerin hepsi Jung’u kullanmıştır. Bazıları Jung'un otoritesine işaret ederek kendi iddialarını kuvvetlendirmek için bazıları ise eleştirse de Batılı emsallerine göre İslami anlayışa daha yakın kabul ettiği için "hedef kitlesini yönlendirmek için Jung’u kullanmıştır. İslami dergiler yazılarında Jung’un "persona", “anima-animus” ve "self” kavramlarını hiç kullanmamışlar. Ama Jung’un “din”, “Tanrı”, “arketip” ve "kolektif bilinçdışı” gibi kavramlarına çok yer vermişlerdir. Özellikle "kolektif bilinçdışı” kavramını İslami bir değer olarak gördükleri için daha çok sahip çıkmışlardır. İslami dergiler Jung’un “otorite” olduğunu kabul ederler. Söz konusu bu “otorite” bazı İslami dergiler için temellendirilen kendi iddialarının "kuvvetlendiricisi" iken bazı İslami dergiler için dünya görüşlerine uygun yönlerinin alınması gereken bir “modeldir”. İslami dergilerin Jung’u kullanırken bilimsel bir üslup ve amaçlarının olmadığı açıktır. İslami dergiler Jung’un kavramlarına yaklaşımları bütüncül değil, “etnosentrik” ve “döngüsel akıl yürütme” şeklinde olduğu sonucuna ulaş1lmıştır. Jung’a ve görüşlerine "İşe 
yarayanı al, yaramayanı bırak" mantığıyla yaklaşan İslami dergiler ile İslami psikolojiyi savunanların “Batı’nın İslami perspektife uyan pozitif yönünü al” mantığının benzer olduğu kanaati ortaya çıkmıştır.

Anahtar Kelimeler: İslami Dergiler, Carl Gustav Jung, Jung'un Görüşleri, Jung Olgusu, Kolektif Bilinçdışı, Doküman Analizi.

\begin{abstract}
Absract
Even during the first establishment of the Republic (with the expression of Balaban), "the science of spirituality (=psychology) that talks about the spiritual existence of man" has always been interesting by the writers of that period. Especially since the 1940s, in some scientific, moral, religious and literary journals published in Turkey, the views of Western psychologists such as Carl Gustav Jung, who are famous in the psychology of religion, were explained. In this research, it has been tried to analyze how C. G. Jung and his views are handled in these journals. The journals discussed in the research are as follows: "Sebilürreşad", "Muslim Voice", "Tawhid", "New Ground", "Orbit", "Academy", "Young", "Cultural World", "Monthly" and "Kur'ani Hayat". In our research, the approach to Jung and his views in these examined journals was investigated and some results were obtained. Accordingly, Jung has a positive phenomenon accepted by the Islamic community, as some Islamic journals acknowledge that Jung is different from their peers". All Islamic journals used Jung. Although some criticize Jung to strengthen their own claims by pointing to Jung's authority, he used Jung to "guide his target audience" because he considered it closer to Islamic understanding than his Western counterparts. Islamic journals never used Jung's concepts of "persona", "anima-animus" and "self" in their articles. But they gave a lot of place to Jung's concepts such as "religion", "God", "archetype" and "collective unconscious". Especially since they see the concept of "collective unconscious" as an Islamic value, they have embraced it more. Islamic journals acknowledge Jung as the "authority". While this "authority" is the "strengthener" of its own claims based on some Islamic journals, it is a "model" for some Islamic journals whose aspects should be taken in accordance with their worldview. It is clear that Islamic journals do not have a scientific style and purpose when using Jung. It was concluded that Islamic journals approached Jung's concepts in the form of "ethnocentric" and "circular reasoning". It has emerged that Islamic journals that act with the logic of "Take what works and leave what does not work" and those who defend Islamic psychology are similar to the logic of "take the positive side of the West that fits the Islamic perspective" to Jung and his views.
\end{abstract}

Key Words: Islamic Journals, Carl Gustav Jung, Jung's Views, The Jungian Phenomenon, The Collective Unconscious, Document Analysis. 


\section{Bazı İslami Dergiler Örnekleminde Carl Gustav Jung: Nitel Bir Araştırma}

\section{Giriş}

Din psikolojisi alanında çalışan her akademisyen Carl Gustav Jung ismini duymuştur. Sadece din psikolojisi akademisyenlerine değil psikolojiye veya dini konulara meraklı yazarlara bile C. G. Jung ismi aşina gelebilir. Nedeni sorulacak olursa muhtemelen Jung’un kendi dönemindeki bilim dünyasında bazı psikolojik kavramları özgürce dile getirmesi ve görüşlerini "Analitik Psikoloji” ekolü adı altında toplamasıdır. Çünkü Jung kendi döneminde “din”, “dindarlık”, "bilinç/şuur”, "bilinçaltı/şuuraltı" ve "kolektif şuuraltı" gibi birçok konuda Freud'dan farklı düşünerek psikanaliz ekolü içinde söylenmeyen birçok şeyi özgürce söylemiştir (Glover, 1991). Jung sadece psikologlar tarafından değil Hristiyan veya diğer dinlerin ilahiyat sahasındaki teologları tarafindan da ilgi çekmiştir (Gebel, 2003).

Türkiye'de de Jung'un görüşleri ilgi çekici olmuştur. Cumhuriyet döneminde harf inkılabından sonra bile Jung'un bazı kitapları Türkçeye çok çeşitli yazarlar tarafindan erken dönemde çevrilmişti. Jung'un kitaplarının en erken çevirilerden biri Dr. M. Hayrullah (1934) tarafindan yapılan "Ruhi Hayatta La Şuur (Inconscient)" çevirisidir. Bazı İslami veya aktüel yazarların dikkatini çeken Jung, günümüzde bile özellikle din ve Tanrı konusundaki birtakım düşünceleri anlatırken Jung'un görüşlerinden istifade ettikleri görülmektedir. Jung'u keşfeden İslami ve aktüel yazarlar onun bazı düşüncelerini İslami ve tasavvufî birtakım inançları ve düşünceleri ispatlamada aracı olarak kullanmışlardı (bkz. Seyhan 2021). Türkiye'deki akademik çevrelerce de referans gösterilen Jung, din psikolojisi alanında uzman olan bazı akademisyenlerce 1940'l1 yıllardan bu

yana bilimsel eleştiriye tabi tutulduğu görülmektedir (bkz. Ülken, 1939). Ayrıca İslami ve aktüel yazarlar ile akademisyenlerin Jung'a bakış tarzları farklı olabilir. Hatta Jung ile Freud'a bakış tarzlarının da aynı olmaması beklenebilir. İşte bu araştırmada İslami ve aktüel yazarların Jung’a bakış tarzlarının nasıl olduğu analiz edilerek araştırılacaktır. Araştırmaya geçmeden önce Jung ve Jung’un psikolojiye getirdiği yeniliklerden kısaca bahsetmek gerekmektedir. 


\section{Jung ve Görüşleri}

Jung Kimdir? Freud tarafindan psikanaliz ekolünün varisi olarak görülen (Schultz ve Schultz, 2007: 640) Jung, 1875 yılında İsviçre’nin kuzeyinde -Kesswil kentinde- Rhine çağlayanın yakınındaki küçük bir kasabada dünyaya gelmişti. Çocukluğunda sıkıntılarla yüzleştiğini anlamaktayız. Kendi ifadesine göre çocukluğu mutsuz ve yalnız geçmişti (Jung, 1961). Babası inancı zayıf, huysuz ve hüzünlü bir rahipken annesi psikolojik rahatsılıkları nükseden bir kadındı. Bazen çok mutlu bir ev kadını iken birdenbire anlamsız şeyler mırıldanan bir büyücü cadı kadın şekline bürünebiliyordu (Schultz ve Schultz, 2007: 640). Çocukluğundan beri içine kapanık, dış dünyaya güvenmeyen, ailesi ile sorunları olan Jung rüyalara, hayallere daha çok güveniyordu. Gelecekte sahip olacağı mesleğini bile rüyasında belirlemişti: “Arkeolog”. Üniversite eğitimi almaya hazır olduğunda hangi alanı seçmeyi düşünürken rüyasında tarih öncesi hayvanların kemiklerini kazıp çıkaran biri olarak kendi görmüştü. Aynı zaman da bu "yerin altını kazma" rüyası, daha üç yaşında iken kendini "yer altı mağarasında" gördüğü rüyası ile örtüşüyordu (Schultz ve Schultz, 2007: 641). Fakat yaşadığı yere yakın bir şehirde arkeoloji olmadığı için tıp fakültesine gitti. Jung, 1900 yılında Basel Üniversitesinden tıp derecesi ile mezun olmuştu. "Yerin altını kazma" ile üç yaşındayken kendisini büyük bir "yer altı mağarasında" gördüğü rüyalar tıp fakültesinden sonra "bilinçaltı" güçleri keşfetmeye yöneltmişti. Bunun için psikiyatri alanına merak sardı ve Jung otuzlu yaşlarında yani 1905 'te Zürih Üniversitesinde psikiyatri alanında okutman olmuştu. Fakat çocukluğundaki rüyaların peşinden koşamaya devam eden Jung, araştırmalar yapmak, yazılar yazmak ve özel girişimlerde bulunmak için birkaç yıl sonra istifasını verdi (Schultz ve Schultz, 2007: 641).

Freud'un "Rüyaların Yorumu” isimli kitabını okuyunca 1900 yılından itibaren psikanalize merak sarmıştı. Hatta 1906 yılında mektuplaşmaya başlayan ikili arasında bağlar kuvvetleniyordu. Bir yıl sonra Freud ile tanışmak için Viyana'ya gitmeye karar vermişti. Viyana' da bir araya gelen ikili uzun yıllar görüşmeyen iki eski dost gibi uzun uzun sohbet etmiştiler. Ancak bu muhabbet ileriki yıllarda çok uzun sürmeyecekti. Onların yakınlığı, Freud'un oğlun babayı yok etmeye yönelik kaçınılmaz arzusunu ifade eden "Ödipal” kompleksinin parçalarını taşıyor olabilirdi (Schultz ve Schultz, 2007: 641). Şu da bir gerçektir ki, Jung Freud ile karşılaşmadan önce beli bir kariyere sahipti. Psikanaliz ekolüne bir öğrenci olarak değil kendi mesleki ününü kazanmış biri olarak 


\section{Bazı İslami Dergiler Örnekleminde Carl Gustav Jung: Nitel Bir Araştırma}

gelmişti. Belki de bu yüzden Freud'un tahakkümü altına girmek istememiş olabilir. Sonuçta ikili arasındaki muhabbet hızlı ve keskin başlasa da Türkçe deyimi ile "yanıp sönen saman alevi” gibi olmuştu. İlişskilerinin ilk başlangıcında eleştirilerini bastırmış olsa da Freud'u sorgusuz sualsiz kabul eden biri olmamıştı Jung. Clark Üniversitesinin töreninde buluşan ikili arasında soğuk rüzgarlar esmesine neden olan birtakım rüya yorumlama krizi olmuştu (Jung, 1997). Olay şu şekilde gerçekleşmişti: İki eski dost birbirlerine rüyalarını anlatırlar. İlkini Freud anlatırken Jung Freud'un rüyasını yorumlamaya çalışmış ancak Freud, Jung’un yorumunu -sanki küçümseyerekdeğerlendirmemiş ve kendi yorumunu dile getirmekten de imtina etmiş, "kişisel otoritemi riske atamam” demiştir. Bu sırada ikinci rüya ise Jung'un rüyasıdır. Bu rüya ise şöyledir: "Duvarlarında göz alıcı tablolar görülen özenle dekore edilmiş modern bir evin üst katındadır. Bu evin kendisine ait oluşu onu hayrete bırakmış ve alt kata doğru inmeye başlamıştır. Alt kat ise üst kattan biraz daha eski ve koyu renklidir. Orta çağ tarzı dekorasyonlu olan alt katta incelemeye başlarken taş sütunlardan oluşan zeminde bir yüzük vardır. Bu yüzük yerinden çekildiğinde aşağı katlara açılan dar taş merdivenler oluşur. Bu merdivenleri takip eden Jung, bir mağaraya iner ve oradaki mağarada kemikler, kırık çömlekler, eski çağdan kalma kalıntılar ve kafa tasları vardır” ve rüya burada bitmiştir (Stevens, 1999).

Freud sıra kendisine geldiği için bu rüyayı tabir etmek zorundadır. Bunun için 1srarla kafatası kalıntılarının kime ait olduğunu öğrenmek ister. Freud'a göre bu kafatası kemikleri Jung’un ölmesini istedikleri kişilere aittir. Jung ise farklı düşünmektedir. Jung’un kendi rüyasına ait tabiri şöyledir: Jung'a göre o ev ruhsal bir imgedir yani Jung'un kendi ruhuna işarettir. Evin en üst katı onun bilinç boyutudur. Bunun için modern bir şekilde tasarlanmıştır. Evin bir alt katı olan ve daha eski malzemeleri olan zemin kat ise Jung'un kişisel bilinçaltıdır. Bu bilinçdışından daha derinlere gitmek ise kolektif bilinçdışıdır. Jung böylece "kendi içindeki ilkel adamın dünyasını keşfetmiştir. Kafataslarının ölmesini veya öldürülmesini istenen kişilerle alakası yoktur. Kafatasları bizim ortak psişik mirasımızı bilinçlendiren geçmiş atalarımıza ait kalıntılardır. Jung’un bu rüyaya getirdiği yorum aslında kendisine ait tüm psikolojik teorilerinin özetini oluşturmaktadır: "Kolektif (Ortak) Bilinçdışı”. Bu yorumu elbette Freud kabul etmeyecektir ve ikilinin eski dostluğu sönmeye başlayacaktır. (Stevens, 1999: $47 \mathrm{vd}$.).

Daha sonra 1912'de "Bilinçdışı Psikolojisi”" (Psychology of The Unconscius) kitabını yazdığında kendi görüşlerinin genel bir ifadesi olduğunu söylerken Freud'un göstereceği tepkiden çekiniyordu 
ama bu kitabın basımı ile kaçınılmaz son ortaya çıkmıştı (Jung, 1949). Ayrıca Yahudi olmadığı için 1911'de Yahudi aleyhtarlığını azaltmak için psikanaliz derneği başkanlığına Freud'un desteği ile getirilen Jung, Freud ile 1912'deki başlayan gerginlik ile ikili arasındaki ilişkiler bitme noktasına gelmiş ve Yahudi karşıtı olduğu ön yargısı ile 1914'te psikanaliz derneği başkanlığından da ayrılmıştı (Schultz ve Schultz, 2007: 643).

Jung ile Freud'un yollarının ayrılmasının bir başka sebebi de Jung'un 1913'te yani 38 yaşında iken şiddetli bir iç çatışma ve duygusal problemler yaşamış olmasıdır. Elbette benzer şeyleri Freud da yaşamıştı. Dahası Jung da bu ağır psikolojik bunalımları atlatmak için Freud gibi yöntemler izliyordu. Jung duygusal açmazlarını Freud gibi bilinçaltı ile yüzleşerek çözmüştü (Schultz ve Schultz, 2007: 643). Peki bunun ikili arasındaki ayrılıkla ne ilgisi vardı? Jung yaşadığı tecrübe ile Freud'dan farklı olarak kişilik ile ilgili alışılmadık bir yaklaşım sergilemişti. Jung'a göre kişilik çocukluk yıllarında oluşup biten bir süreç değildi. Tam tersine kırklı yaşlardan sonra da kişilik değişebilirdi. Freud ile Jung arasındaki farklılıklardan biri kişilik konusuydu. Diğer farklılık ise libidonun niteliğiydi. Freud libidoyu cinsel ağırlıklı bir kavram olarak tanımlarken, Jung libidoyu genelleştirilmiş bir hayat enerjisi olarak ele almıştı. Jung ile Freud arasındaki üçüncü fark ise "şuur/bilinçaltı" kavramıydı. Jung "şuur/bilinçaltı" kavramına daha fazla önem veriyordu ve psikolojiye yeni bir kavram eklemişti: "kolektif şuurdışı/bilinçdışı" (Schultz ve Schultz, 2007: 645).

Din psikolojisi alanı ile alakalı olarak Jung'un yine Freud'dan farklı düşündüğü yönler vardı. Muhakkak bu düşüncelerinde de Jung'un yaşadığı hayat tecrübeleri etkiliydi. Çünkü Jung, 69 yaşında geçirdiği kalp krizinden sonra dine ve dindarlığa çeşitli bakış açıları geliştirdi ${ }^{1}$. Kendi psikoloji ekolünü oluşturan Jung, ruhun metafiziğe ve dinsel bir temaya ihtiyaç duyduğunu öne sürmüştü (Ukray, 2017: 11). Freud'a göre din ve Tanrı tamamen insanların uydurduğu kavramlardı (Okumuş, 2019: 210 vd.). Jung ise farklı düşünüyordu. Tanrı gerçekten var mıydı yok muydu tartışmasına girmeden insan için Tanrının ve dinin lüzumuna ve faydasına bakmıştı. Çünkü Jung'a göre din, sağlıklı olmanın bir göstergesi ve Tanrının varlığına inanmak da nevrozdan kurtaran bir durumdur (Moreno, 1974: 213; akt. Ayten, 2010: 79). Jung din ve Tanrı ile ilgili düşüncelerini tecrübelerine ve araştırmalarına dayanarak söylüyordu: "Otuz beş yaşını geçen hastalarımın hepsi,

\footnotetext{
1 Kronolojik tarzda olmasa da Jung hakkında otobiyografik bilgiler, "Memories, Dreams, Reflections" (Hatıralar, Rüyalar, Düşünceler) adlı eserde bulunabilir. Sambur'a göre bu eser Jung'un hayatı hakkındaki en derin ve otantik kaynak niteliğindedir (2005:13).
} 


\section{Bazı İslami Dergiler Örnekleminde Carl Gustav Jung: Nitel Bir Araştırma}

problemlerinin çözümünde son çareyi hayatlarına dini bir bakış açısı kazandırmakta bulmuşlardı" (Jung, 1933: 264). Denge kavramına dikkat çeken Jung, bireyin çatışmalardan kurtulması için dinlerin psikoterapi sistemleri içinde en gelişmişi olduğunu iddia etmiş̧ir. Dinin yokluğu psikolojik rahatsızlıklara sebep olabilir. Dinin en büyük fonksiyonu psişik sağaltım etkisine sahip olması ve komplekslere karşı psikolojik adaptasyon süreci sağlamasıdır (Jung, 2010). Jung’a göre kişisel bilinçaltındaki kompleksler vardır ve bunlar bazen çatışma yaratabilir işte din bu çatışmalardan bireyi korur. Aynı şekilde din ve Tanrı insanın kolektif bilinçaltındaki arketiplerden olup bunlar bilinç düzeyine çıkarlar. İnsanın davranışlarının genelinin bilinçten ziyade bilinçaltı ve kolektif bilinçaltının eseri olduğunu düşünen Jung, din ve Tanrı kavramını bireyin sıradan bir ihtiyacı gibi olmayıp yadsınamayacağını düşünür (Jung, 1984: 80-81). Bunun için din ve Tanrı kişisel bilinç veya bilinçdışının değil- kolektif (ortak) bilinçdışının bir ürünüdür.

Buraya kadar Jung'un hayatından ve yaşadığı mesleki tecrübelerden bahsedildi. Şimdi çok kısa bir şekilde Jung'un psikolojiye ve din psikolojisine sunduğu bilimsel katkıları aşağıda çizilen Şekil-1 doğrultusunda bahsetmek gerektiğini düşünmekteyiz. Şöyle ki;

Jung'a göre insan ruhu/psişesi üç ana katmandan oluşur: "Bilinç", "kişisel bilinçdış̧" ve "kolektif bilinçdışı”. Fechner'a ait olduğu iddia edilse de Freud ile anılan, buz dağı ve dağın altını gösteren şekle (bkz. https://www.malumatfurus.org/zihin-bir-buzdagi-gibidir-sadece-yedide-biri-suyunuzerindedir/) benzer olarak Jung da insan psişesini okyanus üzerinde duran adaya benzetir. Adanın az da olsa görünen tepe kısmı "bilinç" iken deniz suları tarafından kaplanan kumsal toprakları ve kayalıkları ise "kişisel bilinçdışıdır". Adanın etrafındaki uçsuz bucaksız okyanus suları ise "kolektif bilinçdışıdır". Eğer bu adanın etrafinda kendi gibi birçok adacıklar varsa bu adacıklar da "kolektif bilinçdışı" ile çepeçevre sarılmıştır. Şekil-1'de adaya veya adacıklara benzetilerek çizilen görsel bunu anlatmaya çalışmaktadır. 


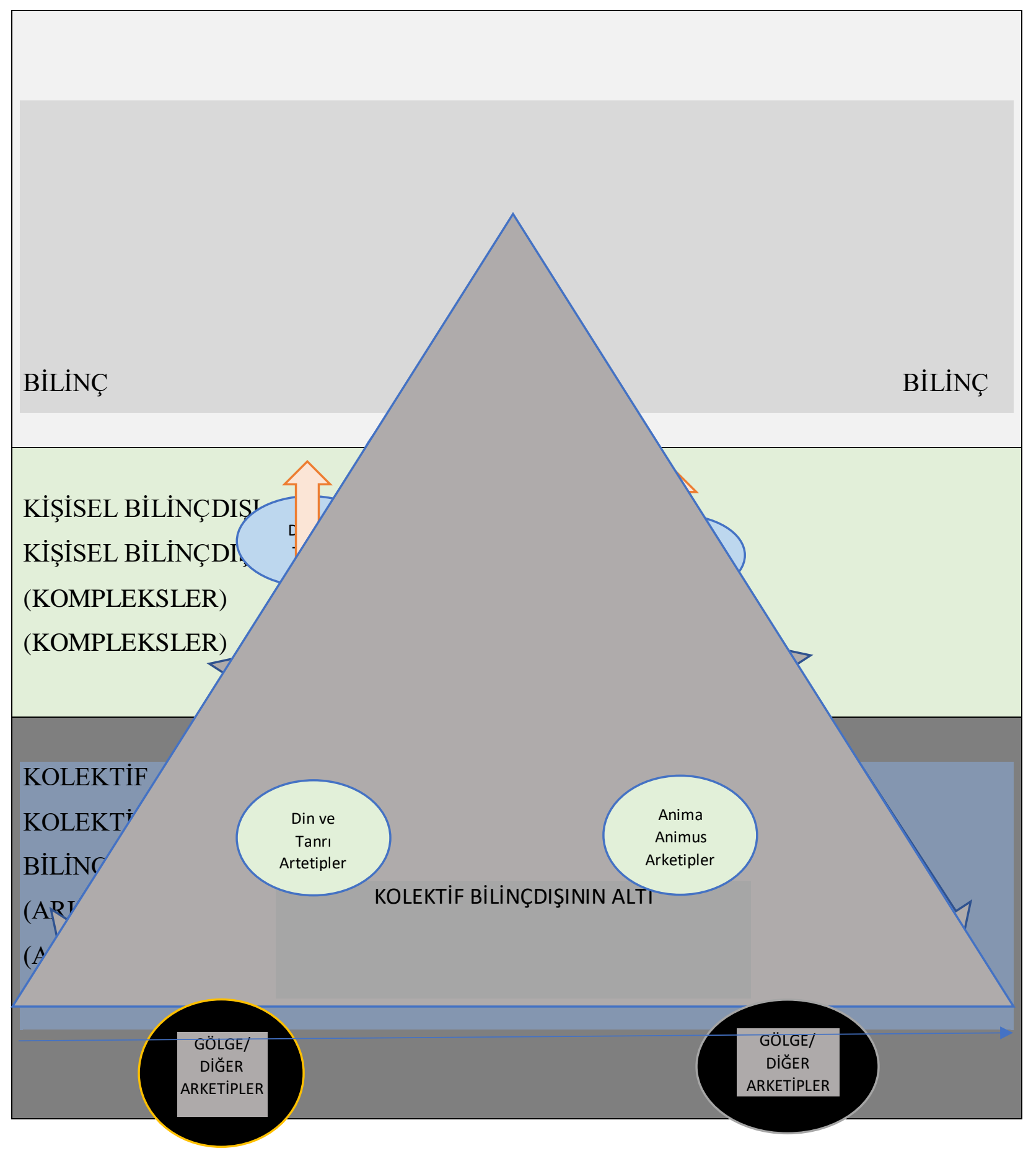

Jung, Freud'dan farklı olarak bilinçdışına değil kolektif bilinçdışına daha fazla önem verdiğini anlamaktayız. Jung'a göre "kolektif bilinçdışı" insanın ilk atalarından miras kalan tüm insanlarda ortak ve bilinçdışı mitolojik karakterli içeriklerin ve arketiplerin bulunduğu kişisel bilinçdışının altında yer alan bölgedir (Jung, 1982: 43-44; Schultz ve Schultz, 2007).Bazı İslami ve aktüel dergilerin dikkatini çeken "kolektif bilinçdışı" düşüncesi bazılarına göre ise Jung'un evrimi 


\section{Bazı İslami Dergiler Örnekleminde Carl Gustav Jung: Nitel Bir Araştırma}

psikolojiye adapte etmesidir (bkz. https://evrimagaci.org/63uçar63deki-canavar-kahramanlarevrimsel-psikolojide-carl-gustav-jungun-arketipleri-8262).

Şekil-1'e bakarak Jung'un psikolojiye sunduğu yeni fikirlerin olduğunu anlamaktayız. İlk olarak şunu diyebiliriz: Kişisel bilinçdışı "komplekslerden", "kolektif bilinçdışı" ise "arketiplerden" oluşur. Kompleksler (zıtlıklar) de arketiplerle bağlantılıdır. Jung, "kişisel bilinçaltının muhtevasını duygusal nitelikli kompleksler oluştururken kolektif bilinçaltının muhtevasını ise arketipler oluşturmaktadır” der (akt. Sambur, 2005: 79). Kompleksler bilinçten bağımsız ve her biri ayrı birer kişilik gibidirler. Komplekslerden arınmış bir kişilik düşünmek mümkün değildir. “Arketipler” ise kolektif bilinçdışının ürünü olup mit, efsane ve masallarda geçen evrensel nitelikteki düşünüşşsekli ya da imaj gibidir. Jung kolektif bilinçdışına daha çok önem verdiği için arketip kavramına da daha çok değinmiştir. Birçok arketip olsa da Jung’a göre en önemli arketipler "anima-animus”, "gölge”, "persona" ve "ben (self)" tir. "Persona" insanın dıştan görünen "bilinç" kısmında kendini gösterir ve "persona" sosyal "rol” veya topluma karşı gerçek kişiliğimizi örten “maskeler” gibidir. Negatif kişiliklerimizi bastırıp bilinçaltına atan "ben” ile yakından ilgili olan persona da gerçek kişiliğimizi toplum önünde maskelemektedir (Sambur, 2005: 94). “Ego” bilinçte bulunup algıları, anıları kapsar ve bizim çevremize uyum sağlayabilmemizi sağlayan gerçeklikle bağlantı kurmanın bir yoludur (Schultz ve Schultz, 2007: 645).

Jung bilince ve egoya çok fazla değer vermez asıl önemli olan bilincin altındaki kısımlardır (Schultz ve Schultz, 2007). "Self” (ben), şekildeki en önemli arketiptir. Kişiliğin ya da psişenin tüm yapısına birlik ve istikrar kazandırır. Kişiliğin tümünü temsil eden ben tam bir bütünleşmeye çabalar. Jung, "self”i kendini gerçekleştirmeye veya kendini kavramaya yönelik bir dürtüye veya ihtiyaca benzetmiştir. "Self” aynı zaman da bilinci ve egoyu hem çepeçevre sarmış hem de merkezi konumdadır (Sambur 2005). Yani "self" (ben) arketipi sadece merkez olmayıp bilinç ve bilinçdışını kapsayan bütün sınırların da kendisidir. Ego bilincin merkezi olduğu gibi ben arketipi de kişisel bütünlüğün merkezidir (Jung, 1968; akt. Sambur, 2005: 101). Bunun için Şekil-1'de üçgen şekilde bilinç ve bilinçaltındaki tüm süreçleri kapsayan desen içinde gösterilmiştir. Aynı zaman da bilincin tam merkezinde de kendini göstermektedir.

“Anima ve animus" arketipleri ise her bir cinsin hem erkeksi hem de kadınsı eğilimler gösterdiği görüşünü yansıtır. Anima erkeklerdeki dişilik özellikleri ile ilgili iken animus ise kadınlardaki erkeksi özellikleri gösterir. Fakat bu arketiplerin bilince yansıması farklı olabilir. Yani erkek olan 
biri kadınsı tarafını tamamen kolektif bilinçaltının en altına iterek sadece erkeksi maskesini takarak yadsıyabilir (Morris, 2002). Tersi durum kadın için de geçerlidir. Bir kadın da erkeksi olan yönünü en derinlere iterek sadece kadınsı yönünü bilincine takabilir. Zaten her arketip mutlaka bilince çıkacaktır diye bir kural yoktur. Jung'a göre bilince hiç çıkmayan bilinçdışı süreçler bireylerde görülebilir. Şekil-1'de bunu "kolektif bilinçdışının altı" olarak gösterilmiştir.

"Kolektif bilinçdışının altı" denilen bölgede insanın en karanlık yönünün olduğu "gölge" arketipi de vardır. Kişiliğimizin hayvansal yanıdır, hayatın daha alt şekillerinden bize kalan ırksal mirastır. Gölge tüm ahlaksızlıkları, ihtirasları ve tüm nahoş arzu ve faaliyetleri içerir. Yani gölge yapmamıza izin vermeyeceğimiz şeyleri yapmamız için bizi zorlar. Bunun için daima bastırılır. Ancak her ne kadar ilkel olsa da bazen yaratıcılık şeklinde ortaya çıkabilir. Bunun için gölge en yüksek ve yüce insani değerlerin yaratıcılığının veya iç görünün ve yoğun coşkuların kaynağını oluşturabilir (Schultz ve Schultz, 2007: 647). Jung'un kendi dönemindeki faşist ve ırkçı eğilimlerin sadece bir kişi tarafindan değil tüm kitleleri harekete geçiren bir toplumsal bir hareket olmasının nedeni aslında gölgedir. Çünkü faşist liderlerden yana olan diğer insanlar kendilerinin hakikatten yana olduklarını düşünerek iyilik yanında yer alarak kötüleri yok etme inancına sahip olabilirler (Jung, 1959: 94; Sambur, 2005: 97). Şekil-1'de kolektif bilinçaltının en dibinde gösterilmiş ve nadiren bilince değişerek çıktığından ok ile gösterilmemiştir.

Son olarak "din ve Tanrı" arketipine gelince Jung şunu der: "Dini arzular doğal bir güdüye dayanmaktadır. Bir insandan ilahlarını alabilirsiniz ama bu karşıllık yenilerini vermek zorundasınız" (Storr, 1973; akt. Sambur, 2005: 149). Tanrı ve din imajı kolektif bilinçdışına ait içeriklerdir. Birtakım sembollerle bilince de yansır. Dahası ise bilince yansımakla beraber bireyin kendini gerçekleştirmede yani bireyselleşmede en önemli faktörlerden biridir. Jung dine çok önem verir. Jung'a göre dinin yokluğu ruhsal hastalıklara sebeptir. Bilinçte dini ve Tanrı'yı inkâr edip bastırmaya çalışırsa birey kişisel veya kolektif bilinçdışında huzursuzluk yaşar. Tanrı ve din arketipi bilince ya simgelerle ya da çeşitli davranışlarla yansır. Kısacası Jung'a göre din ve Tanrı imajı bireysel ve toplumsal sağlık açısından önemlidir. Tanrıya ve dine bağlanmayan birey, dünyanın fiziksel ve ahlaki kışkırtıcılığına kendi kaynakları ile direnemez (Jung, 1999: 61). Freud'un düşüncelerinin tam tersini savunduğunu bu ifadelerden de anlamaktayız.

Yukarıda anlatılanlar genel hatları ile Jung'un görüşlerini ifade etmektedir. Jung'un psikolojiye yaptığı farklı katkılar olsa da araştırmamızın konusu çerçevesince sadece bu kadarı ile 


\section{Bazı İslami Dergiler Örnekleminde Carl Gustav Jung: Nitel Bir Araştırma}

yetinmekteyiz. Şekil-1'de anlatılan görüşler etrafında İslami ve aktüel dergilerin bakış açıları analiz edilecektir. Jung'un görüşleri bazı eleştirilere konu olmuşsa da burada bu eleştirilere anlatmayacağız. Ama İslami ve aktüel dergileri analiz ederken bunlardan yeri geldikçe değinilecektir. Aşağıda yöntem ve bulgular kısmında araştırmaya konu edilen dergilerin Jung ve görüşleri üzerinde bilgiler verilip analiz yapılacaktır.

\section{Yöntem}

Araştırmanın yöntemi anlama temelli olan nitel yöntemdir. Nicel yöntem gibi keşfetmeye ve tümdengelime dayalı değildir anlamaya ve tümevarıma dayalıdır. Araştırma nitel yönteme dayanmakla beraber teknik olarak doküman incelemesi/analizi ile yapılmaktadır. Doküman analizi ya da incelemesi araştırılması hedeflenen olgu veya olgular hakkında bilgi içeren yazılı materyallerin analizidir (Yıldırım ve Şimşek, 2018: 189). Araştırmada Jung'tan bahseden İslami veya aktüel dergilerden bazıları araştırma grubuna dahil edilmiştir. Bu dergiler şunlardır: "Sebilürreşad”, “Müslüman Sesi”. "Tevhid”, "Yeni Zemin”, "Yörünge”, “Akademya”, “Genç”, "Aylık”, "Kültür Dünyası", "Kur 'ani Hayat". Bu dergilerin seçilme şekli ve ölçütü ise "İslami Dergiler Projesi" adlı internet sitesinde yer alan dergilerde Jung hakkında yazılan yazıların olmasıdır. Bunun için araştırmada Jung ile ilgili olgu ve olayların açıklanmasına uygun olan "amaçlı örnekleme" ile bu yönteme bağlı olarak "ölçüt örnekleme" yöntemleri tercih edilmiştir (bu örnekleme yöntemleri için bkz. Yıldırım ve Şimşek, 2018: 118-122).

Araştırmanın deseni "durum çalış̧masıdır". "Durum çalışması", nitel araştırmalarda bir konunun genellikle belli bir özelliğin ya da birkaç durumun derinliğine araştırılmasıdır (Yıldırım ve Şimşek, 2018). Araştırmanın amacı Türkiye'de yayınlanmış bazı İslami (aktüel/edebi olanlar dahil) dergilerin psikolojide alanında tanınan Jung'un görüşlerini ve ona olan yaklaşımlarını araştırmak ve analiz etmektir. Böylece Türkiye'deki din psikolojisi alanına farklı bir bakış açısından Jung değerlendirilecektir. Elbette bu amaca yönelik araştırma yaparken belli sınırlıklar ve varsayımlar içinde yapmak gerekir. Bunun için araştırmanın sınırlıkları seçilen İslami ve aktüel dergilerle sınırlıdır. Ayrıca araştırmada cevaplanması gereken problemlerle sınırlı bir şekilde araştırma 
yapılacaktır. Bunun için seçilen dergilerin araştırmanın amacını ve sınırlılıklarını karşılayabildiği varsayılmaktadır.

Araştırmada cevap aranacak ana problem, "Araşstırmada incelenen İslami ve aktüel dergilerin Jung'a ve onun görüşlerine yaklaşım tarzları nasıldır?" Bu ana problem bağlamında oluşturulan alt sorular ise şunlardır:

a. Araştırmada incelenen İslami dergiler Jung'un hangi kavramlarını kullanmayı tercih etmişlerdir?

b. Araştırmada incelenen İslami dergiler hangi amaçlara yönelik Jung'u ve onun görüşlerini kullanmışlardır?

c. Araştırmada incelenen İslami dergiler Jung'a ve onun görüşlerine yönelik (övücü ve eleştirel) hangi yargilarda bulunur?

Yukarıda oluşturulan problemlere cevap aramak için oluşturulan araştırma gurubundaki İslami ve aktüel dergilerin genel özellikleri ve Jung ve görüşlerinin bulunduğu yazıların genel bilgileri kronolojik açıdan ise şöyledir:

Sebilürreşad Dergisi: Siyasi, dini, ilmi, edebi ve ahlaki dergidir. Mehmet Akif Ersoy'un desteği ile 1908'de Sırat-1 Müstakim adı ile çıkan dergi 1925'te “Takrir-i Sükûn” kanunu ile kapatılıp 1948'in mayısında tekrar günümüz alfabesi ile neşredilmiştir. 1966'da yayımı biten dergi 19081925 yılları arasında 641 sayıya ulaşmış ve 183. Sayıdan itibaren "Sebilürreşad" adını almıştır. Mehmet Akif Ersoy başta olmak üzere Bereketzade İsmail Hakkı, Babanzade Ahmet Naim, Tahirül Mevlevi, Aksekili Ahmet Hamdi, Ömer Rıza Doğrul, Elmalıı Hamdi Yazır, Ali Fuat Başgil gibi tanınmış isimlerin yazıları vardır. 1948 yılında tekrar yayına başlayan dergi 1966'ya kadar 362 kez daha basılmıştır. Haziran 1957'de 10. Cilt 247. Sayı ve sayfa 169'da M. A. Mehtar Faruki’nin “Din ve İlim” adlı yazısının tercümesinde Jung ve görüşlerinden bahsedilmektedir².

\footnotetext{
${ }^{2}$ Buradaki dergiler hakkındaki bilgiler aşağıdaki internet kaynaklarından da görülebilir. Bu bilgilerin bir kısmı buradan elde edilmiştir. Her bir derginin sonuna kaynak vermek yerine aşağıdaki kaynaklar yazılmışırı. Bu dergiler hakkında daha geniş bilgilere ve araştırmalara aşağıdaki linklerden de ulaşılabilir: https://katalog.idp.org.tr/dergiler https://kuranihayat.com/ http://aylikdergisi.com/sayfa-site-hakkimizda-2.html https://www.yorungedergi.com/. https://www.sebilurresad.com.tr/index.php?route=information/information\&information id=1
} 


\section{Bazı İslami Dergiler Örnekleminde Carl Gustav Jung: Nitel Bir Araştırma}

Müslüman Sesi: İzmir'de yayınlanan ve diyanet camiasının sesi olarak bilinen Müslüman Sesi, 17 Kasım 1948 tarihinde İzmir vaizi Mehmet Lütfullah Baydoğan tarafindan aylık olarak çıkartılan “Dini, Ilmi, Ahlaki” dergidir. 1985'e kadar $481 \mathrm{kez}$ yayınlanan dergide diyanet işleri eski başkanlarından Ahmet Hamdi Akseki'nin de yazıları vardır. Siyasi konulardan çok iman ve ibadet esasları, önemli dini alimler, siyer, Kur'an-1 Kerim dersleri olmak üzere ders ve öğüt içerikli bir yayın politikası yürütmüştür. $\mathrm{Bu}$ derginin iki yazarı kendi yazılarında Jung ve görüşlerine değinmiştir. Bu iki yazardan biri Mustafa Rahmi Balaban iken diğeri Hilali Durukan'dır. İsmi belirtilmeyen bir yazarın da yazısı bulunmaktadır. Bu yazı 22 Mayıs 1961'de cilt 13 sayı 204'teki “Ahlaki kökleştiren dindir” adlı yazıdır. Hilali Durukan'ın yazısı ise şudur: 12 Ağustos 1961'de say1 208 sayfa 5'te "Din ve İman”. Yazarı belirsiz yazılar iki tanedir. Birincisi, 8 Kasım 1951 cilt 3 sayı 51'deki "Son Nefeste Tanrıya Dönüş" iken diğer ikincisi, 22 Mayıs 1961'de cilt 13 say1 204’te “Ahlakı Kökleştiren Dindir” adlı yazıdır. Mustafa Rahmi Balaban’ın yazıları sayıca çok olduğu için aşağıda kronolojik olarak şöyle belirtmekteyiz:

26 Ocak 1949'da “Müslüman Sesi” adlı derginin 4. Sayfasında "İnsan iki taraflı aynadır”. 7 Aralık 1949’ da “İnsanın Aslı ve Görevi Hakkında- (Yung) ile İslam Tasavvufu arasındaki Görüş Birliği” yazısıdır. 30 Aralık 1949'da “İnsanın Aslı ve Görevi Hakkında- (Yung) ile İslam Tasavvufu arasındaki Görüş Birliği” (2). 12 Ağustos 1950'de 2. Cilt 32. Sayısında Balaban “Tanrı Kitabından: Sapıklara Uymayalım”. 22 Ocak 1951'de 3. Cilt ve 37. Sayısında "Tanrı Kitabından: Din ve İman”. 11 Nisan 1952 cilt 4 ve 58. Sayıda “Din ve Terbiye”. 3 Mayıs 1952, cilt 4 ve sayı 59' daki “Din ve Terbiye 2". 17 Haziran 1952, cilt 4, sayı 62'de “İlim ve Din Ahengi 3". "İman ve Hayat” (1952, c. 4, s. 68). 18 Temmuz 1953, cilt5 sayı 79' da “Dini Hayatın Amaçları 2”.

Tevhid Dergisi: Haftalık siyasi gazete olarak basılan dergi İran devrimini savunan zihniyettedir. Şura dergisinin kapanmasının ardından İran devriminin arifesinde yayın hayatına başlayan Tevhid, ekseriyetle akıncı gençliğe hitap etmek için yayınlanmıştır. Aralık 1978'de başlayıp Ağustos 1979’da yayını bitmiştir. Yayınlandı̆̆ı dönemde 40 bin tirajı bulmuş çekirdek kadrolarından bazıları ise Ali Bulaç, Hüsnü Aktaş, Beşir Eryarsoy’dur. Derginin 8 Ocak 1979' da 4. Sayısında yazarı belli olmayarak yazılan "Ruhi Hayatta Şuuraltı” başlıklı yazı Jung'un 1934'te tercüme edilen bir kitabı hakkında yazılmıştır.

https://dergipark.org.tr/en/download/article-file/579380 
Yeni Zemin Dergisi: Aylık kültür ve politika dergisi olarak 1993 ile 1994 arası yayınlanmıştır. Nurcu ekolüne bağlı olup 18 sayı yayınlanmıştır. Sahibi Osman Tunç iken baş yazar Mehmet Metiner, Yalçın Akdoğan'dır. Mart 1994, sayı 15 ve sayfa 77'de “Din ve Psikoloji” başlıklı Jung'un tercüme edilen kitabını tanıtmaktadır.

Yörünge Dergisi: Derginin başlığı haftalık haber dergisi iken alt başlığı "Haftalık Yorum ve Aktüalite Dergisi” şeklindedir. Derginin yazım işlerinden sırasıyla Resul Tosun, Mustafa Yürekli ve Mehmet Köse sorumlu olmuştur. Dergi 1990 ile 2000 yılları arasında 466 kez basılmıştır. 27 Mart 1994'te 169. Sayı ve 42. Sayfada “Din ve Psikoloji” başlığı ile Jung’un tercüme edilen kitabını tanıtmaktadır.

Akademya Dergisi: İlim, fikir, sanat ve edebi makalelerden oluşan dergi İBDA yayın organıdır. Üç dönem olarak yayınlanmış ilk dönem olarak 1996-1999 yılları arasında yılda üç kez ve 12 sayı olarak Ergun Oymak ve Yaşar Şadoğlu tarafından basılmıştır. Ağustos 1998 10. Sayı ve 43. Sayfada Jung'un Türkçeye çevrilen Din ve Psikoloji kitabı üzerine Ergün Oymak tarafindan yazılmış “Carl Gustav Jung ve Din” başlıklı yazı bulunmaktadır.

Kültür Dünyası: Aylık kültür, sanat ve edebiyat dergisi olarak bilinir. 1997 ile 1998 yılları arası 19 sayı olarak çıkmıştır. Necip Fazıl Kısakürek hayranlarının çıkardığı bir dergidir. Ekim 1997'de sayı 6'da Mustafa Armağan tarafından yazılan “Rüya, Bilinçaltı ve Şehir” başlıklı yazı Jung’tan bahsetmektedir.

Aylık Dergisi: Aylık olarak yayınlanan siyaset, kültür, ekonomi, toplum dergisidir. İBDA yayın organlarından bir diğeridir. Sahibi Mahmut Bilal İnci'dir. 2004 ile 2016 yılları arasında 147 kez basılmıştır. Kasım 2021'e kadar 206 kez yayımlanmıştır. Jung hakkında çeşitli yazılar çıkmıştır. Bunlardan birisi Temmuz 2014'te, 119. Say1 ve 36. Sayfada Mahmut E. Duru tarafindan yazılan “Sayı Rüyalarının Anlamı Üzerine” adlı yazıdır. İkincisi ise Aralık 2016'da 147. Sayı ve 20. Sayfada Zeynep Nurseli Güleç tarafindan yazılan “Şiirde Rüya; Rüyada Tabir II” adlı yazıdır. Üçüncüsü, Şubat 2009'da 53. Sayı ve 63. Sayfada Gülçin Şenel tarafindan yazılan "Laplace’ın Şeytanı Kuantum Fiziği ve İhtimal Dışı” adlı yazıdır. Dördüncüsü, Şubat 2008'de, 41. Sayı ve 58. Sayfada M. L. Von Franz tarafından yazılan "Bilinçdışı ve Bilimler” adlı yazının Ali Nahit Babaoğlu tarafından tercümesidir. 
Genç Dergisi: Aylık genç dergisi olarak bilinmekte olup "Edebi Genç Dergisi” alt başlıklı ve Abdullah Sert sahipliğinde yürütülmektedir. Nakşi koldan olup altınoluk dergisinin bir yan ürünüdür. 2006-2016 yılları arasında 123 kez basılmıştır. Ağustos 2007'deki 11. Sayıda Süleyman R. Yazıcılar tarafında kaleme alınan "Kendi içimde boğuluyorum" adlı yazıda Jung'tan bahsedilmektedir. Şubat 2015, sayı 101 ve sayfa 20-21'de Yusuf Kaplan tarafindan "bilgi/yorum" yazılan olarak “Batı'nın İslam Düşmanlığının Kısa Bir Arkeolojisi” adlı yazıda da Jung'un birtakım düşünceleri kullanılmıştır.

Kur'an-i Hayat: Temmuz 2008 ile başlayıp günümüze kadar 78 sayı yayınlanmıştır. İki aylık süre içinde yayınlanmaktadır. Daha çok araştırma ve inceleme yazıları yayınlanmaktadır. Araştırmamız yapılırken yayın hayatına devam etmektedir. Akabe Vakfinın yayın organı olup Mustafa İslamoğlu'nun öncülüğünde ve baş yazarlığında çıkmıştır. Jung ile ilgili yazı Mustafa İslamoğlu'nun yazısıdır. "Şahsiyet Eğitim Modeline Girişte Kişilik Tipolojilerinin Yeri -Jung Örneği-" adlı yazı Mart-Nisan 2009'da 5. Sayı ve 20. Sayfada yayınlanmıştır.

Araştırmada okuyucuya kolaylık olması için yukarda bahsi geçen tüm İslami ve aktüel dergilerin -ilk basım tarihleri esas alınarak- yayın tarihlerini, yazılarının başlığını, yazarlarını, kaynakçalarını ve yazı türlerini gösteren bir tablo oluşturulmuştur (bkz. Tablo1).

Tablo-1 İslami Dergiler ve Dergilerdeki Jung ile İlgili Yazıların Genel Bilgileri

\begin{tabular}{|c|c|c|c|c|}
\hline $\begin{array}{l}\text { Dergi Adı ve } \\
\text { Yayın } \\
\text { Tarihleri }\end{array}$ & Yazının Başlığı & $\begin{array}{l}\text { Yazarın } \\
\text { Adı } \\
\text { Soyadı }\end{array}$ & $\begin{array}{c}\text { Yazının } \\
\text { Kaynakçası }\end{array}$ & $\begin{array}{c}\text { Yazının } \\
\text { Türü }\end{array}$ \\
\hline $\begin{array}{c}\text { Sebilürreşad } \\
\text { 1908-1966 }\end{array}$ & Din ve İlim & $\begin{array}{l}\text { M. } \\
\text { Mehtar } \\
\text { Faruki }\end{array}$ & $\begin{array}{l}\text { Haziran } 1957, \text { c: } 10, \\
\text { s: } 247, \\
\text { ss: } 169-172 .\end{array}$ & $\begin{array}{l}\text { Tercüme/Ma } \\
\text { kale }\end{array}$ \\
\hline & $\begin{array}{l}\text { İnsanın Aslı ve Görevi } \\
\text { Hakkında- (Yung) ile İslam }\end{array}$ & & $\begin{array}{l}26 \text { Ocak 1949, c: } 1 \text {, s: } \\
4 \\
\text { ss: } 4-6 \\
7 \text { Aralik 1949, c:2, s: } \\
20\end{array}$ & $\begin{array}{l}\text { Yorum/Maka } \\
\text { le }\end{array}$ \\
\hline
\end{tabular}




\begin{tabular}{|c|c|c|c|c|}
\hline Müslüman & $\begin{array}{l}\text { Tasavvufu Arasındaki } \\
\text { Görüş Birliğgi-1 }\end{array}$ & Mustafa & ss: $4-5$ & \\
\hline \multirow[t]{11}{*}{ 1948-1985 } & $\begin{array}{l}\text { İnsanın Aslı ve Görevi } \\
\text { Hakkında- (Yung) ile İslam } \\
\text { Tasavvufu Arasındaki } \\
\text { Görüş Birliği-1 }\end{array}$ & $\begin{array}{l}\text { Rahmi } \\
\text { Balaban }\end{array}$ & $\begin{array}{l}30 \text { Aralik 1949, c:2 } \\
\mathrm{s}: 21 \\
\text { ss: } 4-5\end{array}$ & $\begin{array}{l}\text { Yorum/Maka } \\
\text { le }\end{array}$ \\
\hline & $\begin{array}{l}\text { Tanrı Kitabından: } \\
\text { Sapıklara Uymayalım }\end{array}$ & & $\begin{array}{l}12 \text { Ağustos } 1950 \text {, c:2 } \\
\text { s: } 32 \text { ss: } 3-4\end{array}$ & $\begin{array}{l}\text { Çeviri/Makal } \\
\mathrm{e}\end{array}$ \\
\hline & $\begin{array}{l}\text { Tanrı Kitabından: Din ve } \\
\text { İman }\end{array}$ & & $\begin{array}{l}22 \text { Ocak } 1951 \text { c: } 4, \text { s: } \\
37 \text { ss: } 4-5\end{array}$ & $\begin{array}{l}\text { Yorum/Maka } \\
\text { le }\end{array}$ \\
\hline & Din ve Terbiye & & $\begin{array}{l}11 \text { Nisan } 1952 \text { c: } 4 \text { s: } \\
58 \text { ss: } 4-5\end{array}$ & $\begin{array}{l}\text { Yorum } \\
\text { /Makale }\end{array}$ \\
\hline & Din ve Terbiye 2 & & $\begin{array}{l}3 \text { Mayıs } 1952 \text { c: } 4 \text { s: } \\
59 \text { ss: } 4\end{array}$ & $\begin{array}{l}\text { Yorum/Maka } \\
\text { le }\end{array}$ \\
\hline & İlim ve Din Ahengi 3 & & $\begin{array}{l}17 \text { Haziran } 1952 \text { c: } 4 \\
\text { s: } 62\end{array}$ & $\begin{array}{l}\text { Yorum/Maka } \\
\text { le }\end{array}$ \\
\hline & İman ve Hayat & & $\begin{array}{l}4 \text { Aralik } 1952 \text { c: } 4 \text { s: } \\
68 \\
\text { ss: } 4-5\end{array}$ & $\begin{array}{l}\text { Yorum } \\
\text { /Makale }\end{array}$ \\
\hline & Dini Hayatın Amaçları & & $\begin{array}{l}18 \text { Temmuz 1953, c: } \\
5 \text { s: } 79 \text { ss: } 3-4\end{array}$ & $\begin{array}{l}\text { Yorum/Maka } \\
\text { le }\end{array}$ \\
\hline & Din ve İman & $\begin{array}{l}\text { Hilali } \\
\text { Durukan }\end{array}$ & $\begin{array}{l}12 \text { Ağustos } 1961 \text { c: } \\
13 \text { s: } 208 \text { ss: 5-6. }\end{array}$ & Yorum \\
\hline & $\begin{array}{l}\text { Son Nefeste Tanrıya } \\
\text { Dönüş. }\end{array}$ & $\begin{array}{l}\text { Yazarı } \\
\text { Belli }\end{array}$ & $\begin{array}{l}8 \text { Kasım } 1951 \text { c: } 3 \text { s: } \\
51\end{array}$ & Eleştiri \\
\hline & Ahlakı Kökleştiren Dindir. & Değil & $\begin{array}{l}22 \text { May1s } 1961 \text { c: } 13 \\
\text { s: } 204\end{array}$ & Yorum \\
\hline $\begin{array}{l}\text { Tevhid } \\
\text { Dergisi } \\
\text { 1978-1979 }\end{array}$ & Ruhi Hayatta Şuuraltı & $\begin{array}{l}\text { Yazarı } \\
\text { Belli } \\
\text { Değil }\end{array}$ & $\begin{array}{l}8 \text { Ocak } 1979 \text { sayı } 4 \\
\text { ss: } 18\end{array}$ & $\begin{array}{l}\text { Kitap } \\
\text { Tanıtımı/ } \\
\text { Yorum }\end{array}$ \\
\hline
\end{tabular}




\begin{tabular}{|c|c|c|c|c|}
\hline $\begin{array}{l}\text { Yeni Zemin } \\
\mathbf{1 9 9 3 - 1 9 9 4}\end{array}$ & Din ve Psikoloji & $\begin{array}{l}\text { Yazarı } \\
\text { Belli } \\
\text { Değil }\end{array}$ & $\begin{array}{l}\text { Mart } 1994 \text { sayı } 15 \text { ss: } \\
77\end{array}$ & $\begin{array}{l}\text { Kitap } \\
\text { Tanıtımı }\end{array}$ \\
\hline $\begin{array}{l}\text { Yörünge } \\
\text { Dergisi } \\
\text { 1990-2000 }\end{array}$ & Din ve Psikoloji & $\begin{array}{l}\text { Yazarı } \\
\text { Belli } \\
\text { Değil }\end{array}$ & $\begin{array}{l}27 \text { Mart } 1994 \text { say } 1 \\
169 \text { ss: } 42\end{array}$ & $\begin{array}{l}\text { Kitap } \\
\text { Tanıtımı }\end{array}$ \\
\hline $\begin{array}{l}\text { Akademya } \\
\text { Dergisi } \\
\text { 1996-1999 }\end{array}$ & Carl Gustav Jung & $\begin{array}{l}\text { Erol } \\
\text { Oymak }\end{array}$ & $\begin{array}{l}\text { Ağustos 1998, say1 } \\
10, \text { ss: } 47\end{array}$ & $\begin{array}{l}\text { Kitap } \\
\text { Tanıtımı/ } \\
\text { Eleştiri }\end{array}$ \\
\hline $\begin{array}{c}\text { Kültür } \\
\text { Dergisi } \\
\text { 1997-1998 }\end{array}$ & Rüya, Bilinçaltı ve Şehir & $\begin{array}{l}\text { Mustafa } \\
\text { Armağan }\end{array}$ & $\begin{array}{l}\text { Ekim } 1997 \text { say1 6, ss: } \\
25 .\end{array}$ & $\begin{array}{l}\text { İnceleme/Ma } \\
\text { kale }\end{array}$ \\
\hline Aylık Dergisi & $\begin{array}{l}\text { Sayı Rüyalarının Anlamı } \\
\text { Üzerine }\end{array}$ & $\begin{array}{l}\text { Mahmut } \\
\text { E. Duru }\end{array}$ & $\begin{array}{l}\text { Temmuz 2014, } \\
\text { s:119, ss: } 36-39\end{array}$ & $\begin{array}{l}\text { İnceleme/ } \\
\text { Makale }\end{array}$ \\
\hline 2004-2016 & $\begin{array}{l}\text { Şiirde Rüya; Rüyada Tabir } \\
\text { II }\end{array}$ & $\begin{array}{l}\text { Zeynep } \\
\text { Nurseli } \\
\text { Güleç }\end{array}$ & $\begin{array}{l}\text { Aralık 2016, sayı } 147 \\
\text { ss: } 20-22\end{array}$ & $\begin{array}{l}\text { İnceleme/ } \\
\text { Makale }\end{array}$ \\
\hline & $\begin{array}{l}\text { Laplace'in Şeytanı } \\
\text { Kuantum Fiziği ve İhtimal } \\
\text { Dış1 }\end{array}$ & $\begin{array}{l}\text { Gülçin } \\
\text { Şenel }\end{array}$ & $\begin{array}{l}\text { Şubat } 2009 \text { sayı } 53 \text {, } \\
\text { ss: } 63-64\end{array}$ & Eleştiri \\
\hline & Bilinçdışı ve Bilimler & $\begin{array}{l}\text { M. L. } \\
\text { Von } \\
\text { Franz } \\
\text { (ter. Ali } \\
\text { Nahit } \\
\text { Babaoğl } \\
\text { u }\end{array}$ & $\begin{array}{l}\text { Şubat } 2008 \text { sayı } 41 \\
\text { ss: } 58-61\end{array}$ & $\begin{array}{l}\text { Tercüme/ } \\
\text { Makale }\end{array}$ \\
\hline $\begin{array}{l}\text { Genç Dergisi } \\
\text { 2006- vd. }\end{array}$ & $\begin{array}{l}\text { Kendi } \\
\text { Boğuluyorum }\end{array}$ & $\begin{array}{l}\text { Süleyma } \\
\mathrm{n} \quad \mathrm{R} . \\
\text { Yazıcılar }\end{array}$ & $\begin{array}{l}\text { Ağustos } 2007 \text { sayı } 11 \\
\text { ss: } 37\end{array}$ & Yazı/Yorum \\
\hline
\end{tabular}




\begin{tabular}{|c|c|c|c|c|}
\hline & $\begin{array}{l}\text { Batı'nın } \\
\text { Düşmanlığı̆ımın Kıs } \\
\text { Arkeolojisi }\end{array}$ & $\begin{array}{l}\text { Yusuf } \\
\text { Kaplan }\end{array}$ & $\begin{array}{l}\text { Şubat } 2015 \text { sayı } 101 \\
\text { ss: } 20-21\end{array}$ & Bilgi/Yorum \\
\hline Kur'an-i & Şahsiyet Eğitimi Modeline & Mustafa & Mart-Nisan 2009 & İnceleme/Ma \\
\hline Hayat & Giriş’te & İslamoğl & say1 5 ss: $20-25$ & kale \\
\hline 2008- vd. & $\begin{array}{l}\text { Tipolojilerinin Yeri -Jung } \\
\text { Örneği- }\end{array}$ & $\mathrm{u}$ & & \\
\hline
\end{tabular}

\section{Bulgular ve Yorum}

İslami ve aktüel dergilerin tanıtımından ve genel özelliklerinden sonra araştırmanın problemleri çerçevesince bulgulardan ve yorumlardan bahsedilecektir. Dergileri incelerken ve bulguları araştırırken kronolojik olarak yani ilk basımı en eski tarihli dergiden en son basım tarihli dergilere doğru bir sıra izlenecektir. Bunun için araştırmamızın çalışma grubundaki en eski basım tarihli dergi olan "Sebilürreşad" adlı dergiden başlanacaktır. Aşağıda ilk olarak, incelenen dergilerde Jung ve görüşlerinin bulunduğu metin içi bilgiler verilecektir. Buna göre;

1. Dergilerde Jung ve Görüşlerinin Geçtiği Metin İçi Bilgiler:

“Sebilürreşad” dergisinin Haziran 1957'de 10. Cilt 247. Say1 ve sayfa 169'da M. A. Mehtar Faruki'nin "Din ve İlim” adlı yazısının tercümesini yayınlamıştır. Kimin tarafından tercüme edildiği belli değildir. M.A. Mehtar Güney Afrika’nın Durban şehrinde bir müellif ve gazeteci olduğu bilgisi yazarın isminin altında verilmiştir. Bu yazısında Mehtar (1957), kendi dönemindeki ilmi ve maddi gelişmelerin insanları maddeci yaptığını, maneviyatı unutturduğunu, Allah inancından uzaklaştırdığını ve öbür dünyanın olmadığı inancına götürdüğünden bahsederek toplumsal ve bireysel sorunların arttığını yazmıştır. Mehtar iddialarını anlatırken yazısında Jung ve kendi görüşlerine uygun olan diğer Batılı düşünürlerden de bahsettiğini görmekteyiz. Mehtar'a göre (1957: 169) “...sadece INSAN’a refah ve saadet getiren, onu muvaffakiyetsizlikten halas eden dine bağlanmak suretiyle kendisini bu delaletten kurtarabilir. Hayatın esaslı maksatlarını hedef tutan, insana hakikati ögreten, yaratılışındaki yüksek manayı ona anlatan sadece dindir”. Mehtar dinin önemine dair bu görüşlerini beyan ettikten sonra iddiasını kuvvetlendirmek için Jung’tan alıntı yapar. Mehtar (1957) şunu yazmıştır: “C. G. Jung, Modern insanı ruhta bulmak adlı 


\section{Bazı İslami Dergiler Örnekleminde Carl Gustav Jung: Nitel Bir Araştırma}

kitabında: "Emniyetle söylüyorum ki, hemen her yaşta bulunan insan, dini akidesi zayıfladığ1 takdirde manevi hastalığa 73uçar olur. Ve dine bağlılığı zayıflamayan hemen hiç kimsede bu hastalık müşahede edilmez” diyor”. Mehtar'ın yazısında Jung'un “din ve Tanrı” konusunda ileri sürdüğü “dinin en büyük fonksiyonun psikolojik sağaltım sağladığı” (Jung, 2010) görüşünü herhangi bir kritiğe ve eleştiriye tutmaksızın aynen almış, kendisinin görüşlerine destekleyici olarak kullanmıştır.

Kronolojik sırada en eski ikinci dergi olan "Müslüman Sesi” dergisinde Jung Mustafa Rahmi Balaban tarafindan çokça bahsedilmiştir. Bunun için kronolojik sıra ile Mustafa Rahmi Balaban'ın yazılarını bir alt başlık altında verdikten sonra Hilali Durukan ve diğer yazarlardan bahsedilecektir.

\section{a. Mustafa Rahmi Balaban’1n Müslüman Sesi Dergisindeki Yazıları:}

Mustafa Rahmi Balaban³, din, ahlak ve tasavvuf üzerine yazdığı yazılarında jung'a dair alıntılar yapmaktadır. Balaban Jung ismini yazısında aynen okunuşu ile vermektedir yani "YUNG" diye yazmaktadır. Aşağıdaki metinlerde alıntı yaparken bazen "YUNG” şeklinde yazılması Balaban'ın kendi ifadesinden kaynaklanmaktadır.

Balaban, ilk olarak, 26 Ocak 1949 tarihli derginin 4. Sayfasında “Insan iki taraflı aynadır” başlıklı yazısında Jung'un "Wirklichkeit Seel” (Ruhun Gerçekliği) eserinden özet bilgiler verir. Balaban (1949a) Jung hakkında “...bugünkü psikolojinin bayraktarlarından Zürih’li Yung...” diyerek öznel bir şekilde tarifte bulunur. Dahası ne kadar önemli ve büyük bir bilim insanı olduğunu anlatırken abartıya kaçtığını hissedebiliriz. Çünkü "Yeni psikolojideki feyizli mesaisine karşı... dünya üniversitelerinin en büyüklerinden on biri fahri doktorluk payesi vermişlerdir. Alman akademisiyle İngiliz akademisinin azasıdır. Ísviçre pratik psikoloji derneğinin reisi olup Zürih'te profesördür” ifadelerini yazmıştır. Bir araştırmacı yazar konusunu anlatmadan önce Jung’tan bahsederken bu kadar yüceltici bir şekilde anlatması bilimsel dil açısından sakıncalı görülebilir. Sanki Balaban yazacaklarının doğruluğunu Jung'un otoritesinin ve kariyerinin büyüklüğüne

\footnotetext{
${ }^{3} 1888^{\prime}$ de İzmir Bergama'ya bağlı Balaban köyünde dünyaya gelen Balaban hem rüştiye hem de çeşitli medreselerde eğitim görmüş ve 1910 'da Daru'I-Muallimin'den birincilikle mezun olmuştur. Çeşitli şehirlerde öğretmenlik ve idarecilik yapan Balaban, Ziya Gökalp döneminde Maarif Vekaleti Telif ve Tercüme Encümeni üyeliğine getirilmiştir. Ziya Gökalp 1924'te milletvekili olunca yerine geçmiştir. Daha sonraları İzmir'in çeşitli liselerinde idarecilik ya pan Balaban 1953'te emekli olmuştur. Aynı yıl ise İstanbul'da vefat etmiştir (1953 ö.). Ömrü eğitim öğretim üzerine geçen Balaban’ın seksenden fazla telif ve tercüme faaliyetleri olup modern eğitim ve öğretime büyük katkıları olmuştur. Kırk üç yıldan fazla süren eğitim ve öğretim hayatında Cumhuriyet Türkiye'sinde Batı tarzı eğitim ve öğretim sisteminin yerleşmesine öncülük eden biridir. Son çalışmalarından biri olan Kuran-ı Kerim'in tercüme ve tefsirini 27. Cüze kadar getirebilmişse de ömrü vefa etmemiştir (Ertan, 1992: 1-2).
} 
dayandırmak istemektedir. Balaban sadece bu ilk yazısında hedef kitlesine Jung'u tanıtmak için Jung'un özellikleri, akademik büyüklüğü ve kariyeri hakkında bu kadar çok teferruata girmiştir. Balaban'ın dergideki diğer yazılarında ayrıntılı bilgi daha azdır. Bu dergideki ilk yazısında Jung'un "kollektif şuurdışı" görüşünü ele alırken insanların özünde birbirine benzediklerini söyler. Jung'un insanlardaki köken olarak benzerliklerine iptidai kavimleri inceleme sonucunda ulaştığını dile getirir. Böylece Balaban (1949a), "kolektif bilinçdışı" ile başlayan Jung’un görüşünü İbrahim Hakkı'nın Marifetnamesinden bir şiir ile tasvir eder. İnsan ruhunun haritasını anlatır gibi Jung'un kollektif şuuraltı görüşüne önem veren Balaban, bu yazısının sonlarına doğru kendi döneminin talim ve terbiye programlarını eleştiriye tabi tutar. Balaban'a göre modern ruhiyat (psikoloji) gençlere yalnız dış aleme intibak ettiren şeyleri öğretir ama derin ruh alemine intibak ettirecek şeyleri noksan bırakır (1949a). Eski ve orta çağlarda bu intibakı din yaparken "reformdan bu yana dinin terbiyevi otoritesi zayıfladı ama yerine de başka bir şey ikame edilmedi” der Balaban. İç ve dış ahengi kuramayan insan yarımdır ve bin tane yarım olan insan bir bütün etmez diyen Balaban, "iç harap olunca dı̧̧ boyalı olsa ne fayda ... için gerçek sağlamlığı namütenahi iyilik kaynağı Yüce Tanrı ile bağlantıyı sağlamlaştırmakladır" diyerek yazsını bitirir (1949a). Bu yazısında açıç̧a Balaban'ın Jung hakkında öznel övücü ifadelerle başlayarak Jung'un "kolektif bilinçdışı" görüşüne değindiğini ve son paragrafta da okuyucuya verilmesi gereken öğüt, tavsiye ve yönlendirmelere Jung'un görüşlerine dayanarak vermesi dikkat çekicidir.

Balaban (1949b), 7 Aralık 1949, cilt 2 ve sayı 20'de “İnsanın Aslı ve Görevi Hakkında- (Yung) ile İslam Tasavvufu arasındaki Görüş Birliği" adlı yazısında Jung'un insan psikolojisi hakkındaki görüşlerini anlatır. Jung'un insanın ruhunun şuur, ferdi şuuraltı ve kolektif şuuraltı olarak iç içe üç katmandan oluştuğunu anlatıp Tasavvufta Hz. Ali’ye isnat edilen kâinatın, insanın özünde mündemiç olduğu sözünü hatırlatır. "Kâinat alem-i kübra iken insan alem-i suğradır" diyen Balaban, Jung'a göre ilk yaratılan şey "kolektif şuuraltına" ait olan arketiplerdir der. Arketip kavramı ile Tasavvuftaki insanın kendi içinde kâinatın özünü barındırdığı anlayışını birleştirmeye çalışan Balaban, Jung'a göre "arketiplerin yekunu insan ruhunda saklı olan şeylerin tamamıdır ki Tanrt-insan-kâinat arasındaki derin münasebetler hakkında beşerin bitmez tükenmez bilgi hazinesidir" der. Bütün mahlukatın mümessili insandır görüşünü desteklemek için Balaban (1949b: 20-21) Jung'un “ontogenetik ve filogenetik” psikolojiler müvazi (dengeli olarak) gider sözünü ifade ettiğini bize aktarır. Arketiplerin bütün kültürlerde aynı olduğu ve bütün mitolojilerde, dini anlatılarda, peri masallarında, dini gelenek ve sırlarda bir olduğu yani kolektif 


\section{Bazı İslami Dergiler Örnekleminde Carl Gustav Jung: Nitel Bir Araştırma}

şuur dışına ait oldukları görülür. Bunun için dinlerin hepsinin en değerli muhtevasının arketipik imaj ve tecrübeler olması sebepsiz değildir der Balaban (1949b: 21 vd.). Jung psikolojisine göre ilk yaratılan arketipler iken diğer varlıklar bundan meydana gelmiştir fikrini ileri sürerek insan ruhunun derinlikleri bu arketiplere ve buradan da Allah'a bitişik olduğunu dile getiren Balaban'a göre insan ezeli ile fani karması bir varlıktır (1949b: 22). Bu yazısında kısacası, Balaban, Jung'un "kolektif bilinçdışı" ve "arketip" görüşlerini Tasavvufun insana bakışı ile örtüştürmeye çalışarak anlatmaktadır.

Balaban 30 Aralık 1949'daki aynı yazısında yani “Insanın Aslı ve Görevi Hakkında- (Yung) ile İslam Tasavvufu arasındaki Görüş Birliği”" adlı yazının devamında, Jung psikolojisi ile tasavvuf esasları arasında kuvvetli benzerliklerin olduğundan bahsederek Niyazi Mısri, Erzurumlu İbrahim Hakkı, Yunus Emre vb. gibi mutasavvıflardan örnek vererek iddiasını ispat etmeye çalışır (1949c). Yazısının son kısmında "Zürihli" Jung'un ilim yolu ile vardığına tasavvuf sezgi ile vardığını ve ikisinin de öğrettiğinin şu olduğunu yazar: "İnsan, hayvanlık insanlık karmasıdır, cami'ülezdaddır" (1949c). Balaban insanın "hayvanlık ve insanlık karması ile cami'ül-ezdad" diye bahsetmesi muhtemelen Jung'un "kişisel bilinçdışındaki kompleks" kavramını çağrıştırmaktadır. Zaten Jung'un kişilik teorisinin zıtlıklar olduğu görüşleri de vardır (Gürses, 2007: 78 vd.). Görülmektedir ki, Jung'un "kolektif bilinçdışı" ve "arketip" görüşlerine ek olarak "kompleks" kavramına da değinmektedir.

12 Ağustos 1950'de 2. Cilt ve 32. Sayıda Balaban "Tanrı Kitabından: Sapılara Uymayalım” adlı bir yazı kaleme almıştır. Bu yazıda iman ile nefis arasındaki savaştan bahseden Balaban (1950), işin başının iman olduğunu, iman kuvvetlenmezse vicdanın galip gelemeyeceğini nefsin galip geleceğini anlatır. Bu görüşlerini desteklemek için Zürihli profesör diye bahsettiği Jung'dan alıntı yapar: "Bugünkü yeni psikolojiyi kuranlardan Zürihli profesör (Yung), insanllğın bugünkü ıstırabının derin kökünü: İnsanların (Allah) ı (Allah yolunu) kaybetmelerinde görür "Allah yolunu bulup o yola düşmedikçe selamet yok. Allah'ı kaybeden insan, kendi ruhunu da kaybetti. Şimdi o emniyetli bir hedeften mahrum, avare bir halde nereye gideceğini bilmiyor. Engin denizlerde pusulasız bir gemi" diyor. Ve profesörün son kitaplarından birinin adı: (Ruhunu arama yolunda olan insanlık) tır”. Görülüyor ki Balaban iddialarını desteklemek için jung’tan alıntı yaparken profesör unvanı kullanıp "bugünkü psikolojiyi kuranlardan..." ifadesi ile Jung'u yüceltmektedir (Balaban, 1950). Bu yazım ve ifade şekli akademik bir üsluba uymaz. Ancak Balaban ögüt ve 
ahlaki ders vermek için görüşlerini desteklemek adına Jung'tan alıntı yapmıştır. Jung'un “dinin en büyük fonksiyonun psikolojik sağaltım” olduğuna dair görüşünü anlatmaya çalışmaktadır. Jung’tan alıntı yaparken de öznel ve yüceltici sıfatları kullanmaktadır.

22 Ocak 1951, 3. Cilt ve 37. Sayıda "Tanrı Kitabından: Din ve Iman" adlı yazısında insandaki din duygusunun fitrî oluşundan bahseden Balaban, yine "Zürihli profesör" diye vasıflandırdığ 1 Jung'tan alıntı yaparak, "insan ruhundaki dengesizliğin ve hastalı̆̆ın en derin sebebi yalnız insan fitratında mevcut olan din duygusunun bozulmasıdır" sözü ile ispatlamaya çalışır. Jung'a göre bu, kubbenin "kent” taşıdır. "Yung teorisinin sentetikliği işte bu noktadadır" diyen Balaban'a göre Jung için din duygusunun başka bir şeyden türemediğini nev'i şahsına münhasır olduğunu aktarır. Jung'tan alıntı yapmaya devam eden Balaban aynen şu ifadeleri kullanır: Yung'a göre "şimdi insanlık, böyle bir tutamağa ve kaynağa, her zamanda ziyade muhtaçtır. Bugün insanlık yalnız Allah'ı kaybetmekle kalmadı. Kendi öz ruhunu da kaybetti. Insanlık bütün o kaybını arayıp bulmalıdır”. Balaban, hiçbir kaynak belirtmeden Jung'un dinin terapi fonksiyonu hakkındaki görüşlerini anlatmaya çalışmaktadır (1952a).

11 Nisan 1952, cilt 4 ve 58. Sayıda "Din ve Terbiye" başlıklı yazıda Balaban, dinin tanımını verirken öznel ve övücü bir ifade ile "Zürihli büyük psikolog Yung'a göre ..." diyerek bir atıfta bulunur (Balaban, 1952a). Bu atıfta dinin tanımı şöyle verilir: “...iyi ve güzel duyguların hepsinin kendinden müsțtak olduğu fitri bir duygudur. İyilik ve güzelliklerin hepsi bu duygudan doğar”. Bu tanımın Jung'un hangi kitabından alındığı ve hangi sayfasında geçtiği belirtilmemiştir. Ancak Balaban, İslami görüşlerini teyit etmek için Jung'u gayet iyi kullandığını söyleyebiliriz.

3 Mayıs 1952, cilt 4 ve sayı 59'daki "Din ve Terbiye 2" adlı yazısında Balaban (1952b), dinin anlam ve öneminden bahsederek Jung'a atıfta bulunur ve Jung'un şöyle dediğini aktarır: "Din duygusu normal şekilde gelişmezse, bozulursa insan; can evinden bozulmaya başlar. Bugünün insanı Allah'ı kaybetmekle yalnız Allah'ı değil kendisini de kaybetti”. Bu cümleyi nereden ve hangi kitaptan alıntıladığı belli değildir. Ancak görüşlerini ispat için Jung'tan aktardığ görülmektedir. Bu yazısını da "Milli tarihe karşı bugünkü borcumuzun Merhum Atatürk'ün modernleşme hamlelerini din terbiyesi ile tamamlamaktır" diyerek bitiren Balaban (1952b) din ve terbiyenin önemini yazısında anlatmış olmaktadır. Araştırmamızda incelediğimiz diğer İslami dergilerin yazılarında Atatürk ile ilgili ifadeler rastlanılmamıştır. Balaban ve Müslüman Sesi dergisi Diyanet İşleri Başkanlığının gözetiminde çıktığı için bu ifadelere rastlamak makuldür. 


\section{Bazı İslami Dergiler Örnekleminde Carl Gustav Jung: Nitel Bir Araştırma}

Zaten aşırı din karşıtlığına karşı çıkarak milliyetçi ve muhafazakâr bir kimlikle din eğitimi ve çeşitli dini konularda bu dergi kamuoyunu yönlendirmişti (İşler, 2018). Aşırı din karşıtlarına karşı din ve ĕgitimini savunurken Jung 'tan bahsedilmesi dikkat çekicidir.

17 Haziran 1952, cilt 4, sayı 62'de "İlim ve Din Ahengi 3" adlı yazısında din, ilim ve ahlak dengesinin önemini anlatmaya çalışan Balaban (1952c), yine Jung’tan referans vererek “Allah’1 unutan da insanlığın doğru yollarından sapar, azar. Bu sebepledir ki, Zürihli Jung, modern insan Allah'1 unutmakla kendi ruhunu da kaybetti” der. "Bu sebepledir ki” ifadesini kullanarak önceki satırlarda geçen kendi düşüncesinin doğruluğunu Jung'u referans göstererek vermektedir.

4 Aralık 1952 'de "İman ve Hayat" (c: 4, s: 68) adlı yazısında Balaban (1952d), dinin sadece öte dünyaya hazırlık olmadığını ve modern psikolojinin gelişmesi ile din artık ruh muvazenesi ve sağlığı için vaz geçilmez olduğunu anlatırken "Zürihli büyük ruhiyatçı doktor Yung” diye bahsettiği Jung'un "Şuuraltı Psikolojisi” adlı eserinden uzun bir paragraf atıfta bulunur. Bu paragrafta Balaban Jung'un görüşleri çerçevesince insanda tanrı ve din duygusunun vaz geçilmez olduğunu din duygusunu itibardan düşürmekle insan psikolojisinin bozulduğunu, şuuru bozulan insanın şuur altının da bozulacağını anlatır. İlimde bu derin keşf ve vukufu Jung'un yaptığını söyleyerek “Yung: İnsan Allah’1 kaybetmekle kendini de kaybetti” der. Ayrıca yazısının sonlarına doğru, Balaban, "Zürih akıl hastalık mütehassısı Yung: Bütün iyiliklerin anası imandır. Bütün kötülüklerin de anası imansızlıktır” diyerek iman ile ilgili görüşlerini ispata çalışır. Bu yazısında da özel ve bilimsel olmayan ifadelere rastlanılmakla beraber Balaban görüşlerini desteklemek için -kaynakça vermeden- Jung’u kullanmaktadır.

18 Temmuz 1953, cilt 5 sayı 79'da “Dini Hayatın Amaçları 2" adlı yazısında da Jung'un yukarıdaki anlattığımız görüşlerine değinen Balaban, "Allah ve din duygusu, ruh yapısının kopmaz bir parçası ve ruhi muvazenenin esasıdır, insanın hal ve hareketlerinde en büyük rol sahibidir. Bu duygu silinince ibadet için harcanan enerji (libido) harcanamadiğından ters dönüp insanlar zehirlenmiş olurlar... " diyerek Jung'un aynı görüşlerini uzun bir paragraf içinde tekrar etmektedir. Balaban (1953), ana başlığın alt başlığında din hakkında "din ilahi tekâmül konumuna uygun bir hayat yaşamaktır” şseklinde dinin bir tanımını yaparak başladı̆̆ı yazısında önceki yazılarında olduğu gibi yazdıklarını doğrulamak ve mantığa büründürmek için Jung’tan referans vermiş ve görüşlerini ispat için Jung'u göstermiştir. Burada Jung’un diğer görüşleriyle birlikte "libido" teriminin kullanıldığ 1 da görülmektedir. 
Journal of Social Research and Behavioral Sciences, Volume: 7 Issue: 14 Year: 2021

\section{b. Hilali Durukan ve Yazarı belirsiz Yazılar:}

12 Ağustos 1961, 13. Cilt ve 208. Sayıda “Din ve İman -5” adlı yazısında Hilali Durukan Jung’tan bahsetmektedir. Durukan bu yazısını Balaban’ın 18 Temmuz 1953’teki yazısından kopyalamıştır. Referans göstermeden noktası virgülüne kadar alıntılamıştır. Balaban'ın yazdığı "Dinin bildirdiği esasları (akıl) seziyor..." İfadesinden başlayarak "Zürihli Yung da şöyle der” ifadesini alıp "Yuvası bulunmadığı için mikroplar yok edilemez" cümlesi ile bitirir. Durukan Balaban'ın ifadelerini aynen alıntıladığı için burada yeni bir şey ortaya koymamaktadır. "Zürihli Yung da şöyle der:” ifadesini aynen Balaban gibi yazarak, Jung'un “Allah ve din duygusu, ruh yapısının kopmaz bir parçası ve ruhi muvazenenin esasıdır, insanın hal ve hareketlerinde en büyük rol sahibidir. Bu duygu silinince ibadet için harcanan enerji (libido) harcanamadığından ters dönüp insanlar zehirlenmiş olurlar..." dediğini kaynak göstermeden ifade etmektedir. Durukan'ın yaptığı akademi dünyasında bilimsel hırsızlık iken sosyal yaşantıda ahlaksızlık günümüz hukuk sisteminde de tazminat gerektiren bir durumdur.

"Müslüman Sesi” adlı dergide yazarı bilinmeyen ama Jung'tan alıntı yapılan iki yazı daha vardır. Bunlardan biri 8 Kasım 1951 cilt 3 sayı 51'deki “Son Nefeste Tanrıya Dönüş” iken diğeri, 22 Mayıs 1961'de cilt 13 sayı 204'te “Ahlakı Kökleștiren Dindir” adlı yazıdır. Her iki yazının da yazarı belli değildir. "Son Nefeste Tanrı’ya Dönüş” yazısında Nazi şeflerinden birinin idam anındaki yaşadığı duygu ve düşünceleri anlatılmaktadır. Bu yazının sonlarına doğru Jung’tan bahsedilmiş ve -aynen alıntılanmış şekli ile- şöyle yazılmıştır: 'Zürihli ruhiyatçı (Yung)'a göre bugünkü insanlı̆̆ın çektiği çile, 18 inci asır materyalizminin getirdiği beladandır. Allah'a iman duygusunu sömürmeye çalışmak...”.

Derginin yazarı belli olmayan "Ahlakı Kökleştiren Dindir” başlıklı diğer yazısında ise ahlak ile din arasındaki ilişki izah edilmeye çalışmış ve yazının sonlarına doğru aynen şu ifadeler yazılmıştır: "Bu sütunlarda adını ve ileri sürmüş olduğu ilmi fikirleri defaatle beyan ettiğimiz Avrupa'nın en büyük profesörlerinden (Yung) diyor ki: "Dünyada her bir iyilik mutlak imandan doğar. Bunun gibi her kötülük da imansızlıtan gelir”. Bu ifadeler bilimsel bir üsluba sığmaz.

Tevhid Dergisinin 8 Ocak 1979 tarihi, 4. Sayısında ve yazarı belli olmayan "Ruhi Hayatta Şuuraltı" adlı yazısında Jung ve görüşlerinden bahsedilmiştir. Bu yazı kitap tanıtımı ve kritiğidir. Jung'un 1916'da yayımlanan "Inconscient" adlı kitabının 1934'te Dr. M. Hayrullah tarafindan Türkçeye tercüme edilen "Ruhi Hayatta La Şuur” adlı eser hakkında yazılmıştır. Bu yazı hem 


\section{Bazı İslami Dergiler Örnekleminde Carl Gustav Jung: Nitel Bir Araştırma}

eleştiri hem de takdir-i şayan bir üslup ile övgü içermektedir. Eleştirilen yönler; a) kitabın Türkçeye tercümesindeki başlığın "La şuur” ifadesinin "şuur altı” olarak kabul edilmesinin gerekliliği ve b) metinde geçen Tanrı ifadelerinin İslami anlayışa uygun olarak "Allah lafza-i Celali” "4ile değiştirilmesidir. Övülen yönler ise, bu kitap "günümüz insanının kafasını meşgul eden hatta allak bullak eden sualler ve meseleler hakkında Dr. Jung'un ne dediğinin tespit edilmesidir". Dahası bu kitap sayesinde siyasilerden Ecevit'in de istifade etmesi tavsiye edilmektedir. Zira Tevhid dergisine göre Ecevit kendisinin tesir altında kalan kişiler arasında Jung'un olduğunu söylemiştir. Bu kitabın tanıtımında çeşitli yorumlar da yapılmıştır. Dahası kitabın tanıtımında dikkat çeken yönlerden biri Jung'u Freud'un karşısında bir rakip olarak kullanılmasıdır. Bu kitapta Jung’un “şuurdışı”, “ahlak anlayışı”, “inanmanın gerekliliği” gibi görüşleri bilim diline uymayan bir üslupla anlatılmıştır.

Yeni Zemin Dergisi, Mart 1994, sayı 15 ve sayfa 77'de "Din ve Psikoloji” başlığı ile Cengiz Şişman tarafından tercüme edilen Jung'un bir kitabını tanıtmaktadır. Bu tanıtımın kimin yaptığı belli değildir. Kısa bir tanıtım içinde Jung’un herhangi bir görüşüne teferruatlı şekilde yer verilmemiştir ama Jung'un akademik çalışmalarının çeşitliliği vurgulanmıştır. Hatta Jung’un kolay anlaşılamayan bir fikir dünyasının olduğu ve psikolojiye "arketipler", "kolektif bilinçaltı", “içedönüklük-dışadönüklük” ve "kelime çağrışım testleri” ile katkı sunduğundan Jung’u anlamak için birçok kitabının okunması tavsiye edilmektedir. Yazının son paragrafında, “Jung'un açıklamaktan çok anlamaya önem verdiğini, hermenetik bir tutum sergilediğini, kişinin deneyimine müdahale etmediğini, diğer psikanalizler gibi hastayı yönlendirici olmadı̆̆l, fenomonolojistler gibi hastanın kendini tanıyıp yorumlamasını tercih eden" bir psikolog olduğu anlatılir.

Yörünge Dergisi, 27 Mart 1994’teki 169. Sayısında “Din ve Psikoloji” başlı̆̆g ile Cengiz Şişman tarafından tercüme edilen Jung'un kitabını tanıtmaktadır. Yeni Zemin dergisi ile aynı konu, başlık ve içerikle kitap tanıtımı yapmaktadır. Yeni Zemin dergisindeki yazının (yukarıda tırnak içinde gösterdiğimiz) son paragrafı hariç geriye kalan her kelime, cümle, satır, paragraf vb. her şey aynıdır. Elbette bu bilimsel bir üsluba sığmaz.

\footnotetext{
${ }^{4}$ Bu ifade dergide aynen bu şekilde geçtiği için böyle kullanılmıştır.
} 
Akademya Dergisi de Ağustos 1998 10. Sayı ve 43. Sayfada “Carl Gustav Jung ve Din” yazısı ile Cengiz Şişman tarafindan tercüme edilen "Din ve Psikoloji” kitabı üzerinden Jung ve düşüncelerini eleştirir ve İslami camianın Jung hayranlığına bir darbe vurmak amacını güder. Erol Oymak (1998: 43-44) tarafından yazılan eleştiri yazısı Jung’un diğer Batılı psikologlardan farklı olduğu vurgusu ile başlar ve akabinde Jung'u eleştiriye başlar. İlk eleştirisi, psikolojisinde bir din düşüncesinin olduğu görülse de Jung’ta "Hak Din” kavramının olmamasıdır. Ayrıca ruhi meseleleri ampirik (tecrübi) ve fenomenolojik metod ile değerlendirmesinin sı̆̆ olduğu şu örnekle anlatılır: "Namaz kıldım içime bir huzur geldi demek ki İslam iyi bir şeymişs". Yani dini konular bu kadar da sübjektif, basit ve öznel bir şekilde anlatılmamalı demek ister Oymak. Jung'un “kolektif şuurdışı” kavramını İslam'ın ve özelde de İBDA anlayışının bir kavramı olarak Batı'da ilk olarak dile getiren kişidir. Ancak bu kavram ile sanki insan kendi doğduğu çevrede karşılaştı̆̆ din içinde hiçbir hata yokmuş gibi kendi hakikatini bulacak gibi yaklaşması Oymak tarafindan eleştirilir. "Tanrı'ya inanıyor musunuz?” sorusuna Jung’un "Hayır fakat biliyorum” demesinin aslında onun kafasında ömür boyunca "Allah mı insanı yarattı yoksa insan mı Allah' l yarattı?" sorusu netlik kazanmadığını gösterir der Oymak (1998: 44). Kısacası Cengiz Şişman tarafindan tercüme edilen kitap üzerinden Jung'un din ve Tanrı görüşleri hem eleştirilmiş hem de anlatılmaya çalışılmıştır. Hatta tercümanın tercümanlığı bile yazıda sorgulanır. Oymak’a göre Cengiz Şişman jung'u tam anlamı ile anlamamıştır. Çünkü Jung'un tam anlamı ile "dinsiz” ya da "dindar" olup olmadığı anlaşılmamaktadır. Oymak (1998: 43-44) çok katı ve -kendi dünya görüşünü ve kültürünü merkeze alarak- etnosantrik bir şekilde Jung'u ve Jung'un din ile Tanrı görüşünü eleştirmektedir.

Kültür Dünyası dergisinin Ekim 1997 ve sayı 6'da Mustafa Armağan (s.25) tarafindan yazılan “Rüya, Bilinçaltı ve Şehir” başlıklı yazı Jung’tan bahsetmektedir. Bu yazı Jung'un manik, depresif psikoz teşhisi konulmuş bir hastasının intihar etmeden önce gördüğü ve içinde bir şehrin geçtiği rüyanın tahlilidir. 22 yaşındaki İspanya'da bulunan bir Fransız hasta gencin rüyası şöyledir: "Toledo katedralinin bir sarnıç bulunuyor. Sarnıç suyu Tage nehri ile yer altı bağlantısı varmış. Sarnıç karanlık küçük bir odada ve odanın içinde gözleri kıymetli taşlar gibi parlayan büyük bir yılan var. Yılanın yanı başında altın bir kupa ve içinde hançer bulunuyor. Bu hançer Toledo şehrinin anahtarı ki anahtara sahip olan tüm şehre sahip olacak. Güya bu yılanla B.C. adlı yedi yaşında bir çocuk bu yılanla dost olduğunu öğrenince yılanla konuşur: "Yı1lan B.C.'nin dostu olduğum için İspanya'nın bana ait olduğunu söylüyor ve benden çocuğu kendisine geri vermemi 


\section{Bazı İslami Dergiler Örnekleminde Carl Gustav Jung: Nitel Bir Araştırma}

istiyor bunu kabul etmiyorum". Bunun üzerine hasta rüyasında yılanın yanına gidip kendisini okşatmaya izin verir ama bundan da çekindiği için Magripli bir arkadaşı olan S.'nin yılanın yanına gitmesini ister. Çünkü Mağripli genç atalarından gelen bir kuvvete sahiptir ve antik kılıç kuşanarak sarnıç odasına inmesini Mağripli gence söyler. Böylece Mağripli arkadaşı kılıç arayarak sarnıç odasına gider ve sarnıçta arkadaşından sol avucunu kılıçla delmesini ister ve arkadaşı da deler. Ancak yılandan çekindiği için arkadaşı Mağripli genç orada fazla kalamaz. Toledo şehrinin anahtarı olan hançeri alamadan merdivenlerden çıkar ve Toledo şehrine hâkim olmaz." Mustafa Armağan bu rüyanın Jung tarafından nasıl yorumlandığını yazısında anlatır. Jung'a göre bu rüyanın tabiri şöyledir: Sarnıç kilisenin altında yer alan karanlık ve içinde su bulunan bir kuyudur ve kuyudaki yılan ruhun iç kısmını, karanlık tarafinı ve bilinçaltını, ötekileri yani düşmanlarımızı yansıtır. Kupa defineyi sembolize eder. Kupanın içindeki anahtar hastanın kurtuluşudur ve yılanla korunması ise Batı geleneğinde yılanın düşman ve zararlı varlık olarak görülmesindendir. Rüyayı gören hastanın arkadaşı S. İse hastanın kendi gölgesi yani nefsidir. Yılanın yanına yani mağaraya girmesi ve anahtarı alması istenir ama girmez merdivenlerden çıkarak gider ve hasta artık şehre hâkim olamaz. Jung bu rüyayı sadece bu kadarı ile yorumlamaz aynı zaman da Toledo şehrinin eski sakinleri olan Müslümanlar ile Batı kültürün karşılaştırmasını ve Hristiyanlığın eleştirmesini de yapar (Armağan, 1997: 25-26). Zaten Armağan için önemli olan nokta da budur. Jung'a göre Hristiyanlık Batılı insanların iç dünyalarını en derin düzeyde etkilemektedir. Çünkü Hristiyanlık tarihi itibariyle kendisinden önceki dinlerin akışından kopup öncekileri boğarak üzerine inşa edilmiştir. Kiliselerin putperest tapınaklarından esinlenerek onların üzerine inşa edildiği düşünülürse tapınakların izleri örtülmüş ve yok olmuştur. Toledo katedralinin altındaki yılanlı sarnıç da bu tür eski yeri sunmaktadır (Armağan, 1997: 26). Armağan’a göre rüyadaki yılan, yer altı, bastırma eylemi, mağara, korku, hançer, kupa gibi imgeler İslamiyet'in Batıdaki imgeleriyle örtüşmektedir. İslamiyet tıpkı putperestlik gibi Endülüs’te yerin altına itilmiştir. İslamiyet'in her an ortaya çıkması Batı zihniyetinin korkulu rüyasıdır. Batı imgelerinde yılanın korkutucu bir güç olarak görülmesi, yılanın şeytanla, şeytanın da İslam ile özdeşleştirilmesi İslam’ın “yeraltına itilmiş" bir yılan/canavar gibi görülmesidir. Jung’a göre hastanın gölgesi yani kendisi bu imge ile karşı karşıya gelip yüzleşseydi yani merdivenlerden çıkıp gitmeseydi durum farklı olabilirdi. Jung şunları da der: "Hasta eğer karanlık dünyasıyla yüzleşseydi ve karanlık dünyasını örten Hristiyanlık bilincini aralayacaktı. Bunun yerine ne yaptı? Sorununu bilinçaltına itti’. Jung'un bu ifadelerini yazdıktan sonra Armağan (1997), genel bir sonuca giderek şu ifadelerle yazısını 
tamamlar: "Hastanın şahsında Avrupa zihniyeti, İslam'la yüz yüze gelme şansını yine kaçırmıştır...".

Kültür Dünyasındaki bu yazıda Jung’un “kolektif bilinçdışı, rüya yorumları, gölge, bilinçdış1, putperestlik ve Hristiyanlığa bakış açısı” gibi düşüncelerinin edebi ve kültürel bir anlatımla verilerek yazarın Batının İslam korkusuna anlatmaya çalışması dikkat çekici bir bulgudur.

Aylık Dergisinin Temmuz 2014'te, 119. Sayı ve 36. Sayfada Mahmut E. Duru tarafından tercüme edilen Jung'un "Sayı Rüyalarının Anlamı Üzerine” adlı yazısı vardır. Duru tarafindan yapılan Jung'a ait metnin tercüme çalışmasıdır. Bu tercümeyi neden ve hangi amaçla yaptığı yazılmamıştır. Ancak tercümenin son paragrafında tercüman niyetini açık eder (Duru, 2014: 40). Burada sayı rüyalarının sayılar arasındaki bağlantılar üzerindeki bilinçli yapılar değil bilinçdışı köklerinin analizleri yapılmaktadır. Çok uzun analizlere yer verilse de özet olarak bir tane analizden bahsedebiliriz. Buna göre 33 yaşında ve çocuk sahibi olmayı arzulayan bir kadının rüyasıdır ki rüyasında “Luka 137” şeklinde rüya görür. Kocasının yaşından ve kısırlığından dolayı kocasından çocuk sahibi olma ihtimali zayıftır. İkinci bir evlilik yapıp yapmayacağına dair kaygılar taşımaktadır. Luka'nın İncil' de geçen bir bölüm olduğunu bilemeyecek kadar da dindarlık seviyesi düşüktür. Jung'a göre rüyayı gören kadın Kitab-1 Mukaddes’i hiç okumadığı düşünülürse bu rüyanın bir kriptomnezi olarak kabul edilmelidir. Jung, Luka 137'yi Luka 13: 7 olarak böldüğünde kısır kalma kaygısı çeken kadının bilinçdışı ile ilgili işaretler çıkmaktadır. Çünkü Luka 13:7'de İsa'nın meyve vermeyen bir incir ağacının kesilmesini bir bağcıya anlattığı bir pasaj vardır. İncir ağacı kadim zamanlardan beri erkek üreme organını temsil ettiğini söyleyen Jung'a göre, rüya sahibi kadının kısır kocası hakkındaki (öldürme, cinsel organını kesme veya koparma, yaralama vb. gibi) vahşi duygularının yansımasıdır. Mahmut Duru, bu rüya ile ilgili metni neden tercüme ettiği anlaşılmaktadır: “Jung’un Luka 137” ile ilgili söylediklerine ek olarak şu bilgiler, İBDA Mimarının rüya verilerine lügat ve ebced metotlarını uygulamasının yerindeliğini ve verimliliğini çarpıcı bir şekilde göstermektedir": "Furkan "Lugat-1 Salihun'dan": LUKA: $(\mathrm{Lam}+\mathrm{vav}+\mathrm{kaf}+\mathrm{elif}=30+6+100+1=137)$. " Bu yazıda da Jung'un rüya tahlillerinin siyasi ve kültürel bir dergide anlatıldığı görülmektedir.

Aylık Dergisinin Aralık 2016'da 147. Sayı ve 20. Sayfada Zeynep Nurseli Güleç tarafından yazılan “Şiirde Rüya; Rüyada Tabir II" adlı yazı bulunmaktadır. Bu yazı Freud, Jung ve diğer psikanalizlerin rüya anlayışı rüya üzerine yazılmış zannedilebilir ancak yazıda İslami ve edebi 


\section{Bazı İslami Dergiler Örnekleminde Carl Gustav Jung: Nitel Bir Araştırma}

kültürde rüya hakkında yorum yapılmıştır. Güleç yazısının başında Batıyı ve Batılı psikanalizleri ve nihai olarak Jung’un rüya hakkındaki görüşlerini eleştirir. Ancak Jung’tan bahsederken bazen Jung'u takdir eden ifadelere da rastlanır (Güleç, 2016: 20-21). Jung'un görüşleri hakkında çok ciddi bir aktarım gözükmese de Güleç, Jung’un rüyaları “şuuraltı” olarak yorumladığını ve rüyaları kalıtımla kazanılan tecrübelerin oluşturduğunu ileri sürerek rüyalarla mitleri benzeştirdiğinden bahseder.

Aylık Dergisinin Şubat 2009'da 53. Sayı ve 63. Sayfada Gülçin Şenel tarafından yazılan “Laplace’ın Şeytanı Kuantum Fiziği ve İhtimal Dışı” adlı yazı da Jung hakkındadır. Şenel, Adam Fawer tarafından yazılan "İhtimal Dışı” adlı romanını tahlil ederken Jung’un "kollektif şuuraltı” meselesinden de bahsettiğini söyler. “İhtimal Dışı” romanın Jung’un “kolektif şuuraltı” görüşünü tezine dahil ettiğini ve güya evrim teorisindeki tek hücreli canlıdan meydana gelen bebek annesini emmeyi kalıtımla öğrenemeyeceğine göre zamanın ileri geri hareketi ile bu "kolektif şuurdan" öğrenebilirmiş diye eleştiride bulunuyor Şenel (2009). Romana göre güya “dehaların da kolektif şuuraltını kullanabildiğini ve zaman içinde hareket ederek dinlerin ve kuantum fiziğinin yeni ulaştığı bilgilere ulaşabildikleri” anlatımını Şenel İBDA hareketinin ilerinin bazı görüşleri ile eleştiriye tabi tutuyor. Bu yazıda Jung ve görüşleri doğrudan eleştiri konusu değildir ancak Jung’un "kolektif şuuraltı” görüşünü kullanan Fawer'in romanını eleştirirken bahsedilmektedir. Şenel (2009), Jung'un “kolektif bilinçdışı” kavramının evrim teorisi ile anılmasını ya da yorumlanmasını eleştirmektedir.

Aylık Dergisinin Dördüncü yazısı ise Şubat 2008'de, 41. Sayı ve 58. Sayfada M. L. Von Franz tarafından yazılan "Bilinçdışı ve Bilimler" adlı yazının Ali Nahit Babaoğlu tarafından tercümesidir. Yazıda Jung'un "kolektif şuurdışı”, “arketip”, “eş zamanlılık” görüşleri ile yola çıkarak modern tabiat biliminin ve evrimin farklı okunmasını sağlayabileceğine dair fikirler ileri sürer. Mesela, biyolojiye de yeni bir 1şık serpmiş olacaktır. Bitki ve hayvanların nadiren "işe yarayan" tesadüfen mutasyon geçirdikleri anlayışı yerine Jung'un "kolektif şuurdışı" ve "eş zamanlılık" anlayışının mutasyon sırasında daima "işe yarayan” tesadüfi mutasyonların olduğunu açıklamaya yardımcı olabilirdi. Buradaki "eş zamanlılık” arketiplerin sadece ruhi olaylarda bulunması değil aynı anda dışa yansıyarak bedeni olaylarda da kendini göstermesidir. Buna "psikoid" denildiğini yazıdan anlamaktayız (Franz, 2008: 59). Ayrıca Jung'un "undus mundus" diye bahsettiği olayın günümüz bazı fizikçilerinin de kabul ettiğini görmekteyiz der Franz. "Undus 
mundus" kavramı ile alemin madde ve ruhta aynı olduğunu farklı olmadığını söyler Jung. Kısacası Franz, Jung'un anlaşılması gerektiği ve görüşlerinin birçok bilim alanına aktarılmasını tavsiye eder (Franz, 2008). Böylece bu aktarımın birçok ferde daha dürüst daha ahlaklı olmasını ve daha bilinçli bir tavır sağlayacağını da ekler. Bir İslami dergide böyle bir yazının çıkma gayesinin bu son cümle olduğunu bize düşündürmektedir.

Genç Dergisinin Ağustos 2007'deki 11. Sayıda Süleyman R. Yazıcılar tarafinda kaleme alınan "Kendi içimde boğuluyorum" yazısında Jung'un din anlayışı anlatılmaktadır. Bu yazının yazılmasına neden olan olay şudur: Bir internet sitesinde gencin birinin yaşadığı psikolojik bunalımından bahsetmesi ve kendi içimde boğuluyorum" ifadesini kullanmasıdır. Buradan yola çıkarak Yazıcılar (2007) günümüz gençlerinin birçoğunun dinden uzaklaştığı için psikolojik bunalım yaşadı̆̆ını anlatır. Yazıcılar, yazının gayesinin din hakikatini Jung'tan öğrenmek olmadığını belirtir dahası bir Müslüman olarak zaten dinin ehemmiyeti hakkında yeterli bilgiye sahip olduğunu söyler. Jung'tan asıl bahsetme nedeni ise Jung'un din hakkındaki görüşünün az da olsa bir hakikat içerdiğini ve bu hakikati din karşıtı olan hem psikologlara hem de psikiyatri doktorlarına elinin tersi gibi çarpmaktır. Yazıcılara göre Jung, din hakkında şöyle demektedir: "Nedir dinler? Dinler psikoterapik sistemlerdir. Peki biz ne yapıyoruz biz psikoterapitler? Biz insan zihninin, psişesinin ya da insan ruhunun ızdırabını dindirmeye çalışıoruz. Dinler de aynı sorunla uğraşıyor. Tanrının bizzat kendisi iyileştiricidir.... Dini psikoterapik bir sistem olarak ifade ettiğimde kelime oyunu yapmıyorum. Dahası din, bu sistemin en mükemmel olanıdır; ardında büyük bir pratik gerçeklik yatar".

Genç dergisinin Şubat 2015, sayı 101 ve sayfa 20-21'de Yusuf Kaplan tarafindan "bilgi/yorum" yazılan olarak "Batı'nın İslam Düşmanlığının Kısa Bir Arkeolojisi” adlı yazıda Jung'un Hristiyanlık ve Batı düşüncesi kullanılmıştır. Kaplan yazısında "Çağın büyük psikanalizlerinden Carl Gustav Jung sözünü bahsettiğim bu gerçeği çok iyi görmüş ve çözümlemiş̧ir: "Batılılar neredeyse sahip oldukları her şeyi Müslümanlardan aldıkları için, Müslümanlara karşı aşağılık kompleksine sahiptirler. O yüzden Müslümanlara normal bir insan gibi bakmiyorlar. Fobiyle ürkerek bakıyorlar." Demektedir. Batılıları eleştiren yazısında Jung'un Batılı Hristiyan dünyasını eleştiren bir görüşünü kullanmaktadır.

Kur'ani Hayat Dergisinin Jung ile ilgili yazısı Mustafa İslamoğlu'na aittir. Yazının türü inceleme olarak geçer ve "Şahsiyet Eğitim Modeline Girişte Kişilik Tipolojilerinin Yeri -Jung Örneği-" 


\section{Bazı İslami Dergiler Örnekleminde Carl Gustav Jung: Nitel Bir Araştırma}

başlıklıdır. İslamoğlu, Yazısına Jung'un Eranos konferansında "Ashab-1 Kehf kıssasını yeniden doğuş" olarak yorumlaması hakkında başlar. Kuran'ın Kehf suresini "Yeniden doğuş" gizemi olarak gören Jung, Musa-Hızır olayına değindikten sonra surenin son meseli olan Zülkarneyn meseline gelince İslamoğlu'na göre Jung çuvallamıştır. Jung şunları söyler: “Kur'an'da nadir oldukları söylenemeyecek tutarsızlıklar burada da var. İki boynuzlu anlamına gelen Zülkarneyn'e yani Büyük İskender'e bu ani geçiş tutarsızllk değil de nedir?" diye sorar Jung. Ancak bu çuvallaya kızmayacağını belirten İslamoğlu, Batı1ı bir insandan Kur'an'ın bir suresini yoruma tabi tutması başlı başına bir olaydır der. Jung'tan çok daha beterlerin olduğu düşünülürse, İslamoğlu'na göre, Jung gibi insanların Kur'an'1, Hz. Muhammed'in yazdığını kabul edip İslam peygamberini bir kitap yazarı olarak eleştirmeleri garipsenmemelidir. İslamoğlu, Jung'u kişilik tipolojilerinden başlayarak kritiğe tabi tutar.

İslamoğlu'na göre, Freud ile Jung arasındaki fark, Aristo maddeciliği ile Eflatun'un ideac1 metafiziğidir. Jung, Eflatun'a daha yakın durduğu için Jung bizden biri gibi duruyor. Ancak Jung'un bizden bazı şeyleri bilmediğini ama bilseydi daha iyi olurdu şeklindeki bazı kavramları sıralar. Bunlardan biri, Kuran'ın “Akleden Kalp” ifadesi, ikincisi, kişilik teorisindeki zıtlık yani ezdad (iki zıttan biri olunca diğeri olmaz) anlayışı yerine ezvac (iki zıttan biri olunca diğeri de olur) anlayıı̧ı, üçüncüsü ise kişilik tiplerini tanımlayıcı olması yerine tanıyıcı olmasıdır. Arketipler de "tespit" yerine "teşhis" ise daha iyi olacağını beyan eden İslamoğlu, Jung'un kavramlarının "Freud'un "şehvet" güdüsüne dayalı psikanaliz sistemiyle kıyaslanamayacak kadar değerlidir" der. Jung'un başarıyla tasnif ettiği mizaç tipolojilerini ise İslamoğlu çok değerli bulur ve bu mizaçlar Allah'ın bir lütfudur. Eğitim açısından farklı mizaçlara sahip olan kişileri terbiye etmek İslami "şahsiyet eğitim modeli” açısından değerlidir. Mesela, "Hz. Ebu Bekir'in mizacı ile Hz. Ömer'in mizacı farklı olup bu farklı mizaçların terbiyesinden farklı değerler ortaya çıkar." Der İslamoğlu. Hz. Ömer'in sert mizacı eğitilirse şecaatli, cesaretli kişilik elde edilirken, doğru bir eğitim modeli ile Hz. Ebu Bekir'in mizacından pısırık yerine halim ve selim bir kişilik ortaya çıkar. İslami "şahsiyet eğitim modeli" için Jung'un arketipleri “Tespit” yerine "Teşhis" olarak görülürse bu eğitim modeli için alıp kullanırız diyen İslamoğlu, işe yarayanı alıp kullanma adına Jung’tan istifade edebilecek birçok yönün olduğunu düşünmektedir. 


\section{Araştırmanın Problemlerine Göre Bulgular ve Yorumlar:}

$\mathrm{Bu}$ başlık altında araştırmada sorulan problemlere ilişkin yorumlar anlatılacaktır. Ancak bu yorumlara geçmeden önce araştırmada analiz edilen dergilerin "genel ve alt" özelliklerine göre bir tasnif yapılacaktır. Buna göre aşağıda Tablo-2'de dergilerin tasnifi şöyledir:

\section{Tablo-2 DERGILERIN GENEL VE ALT ÖZELLIKLERINNE GÖRE SINIFLANDIRILMASI}

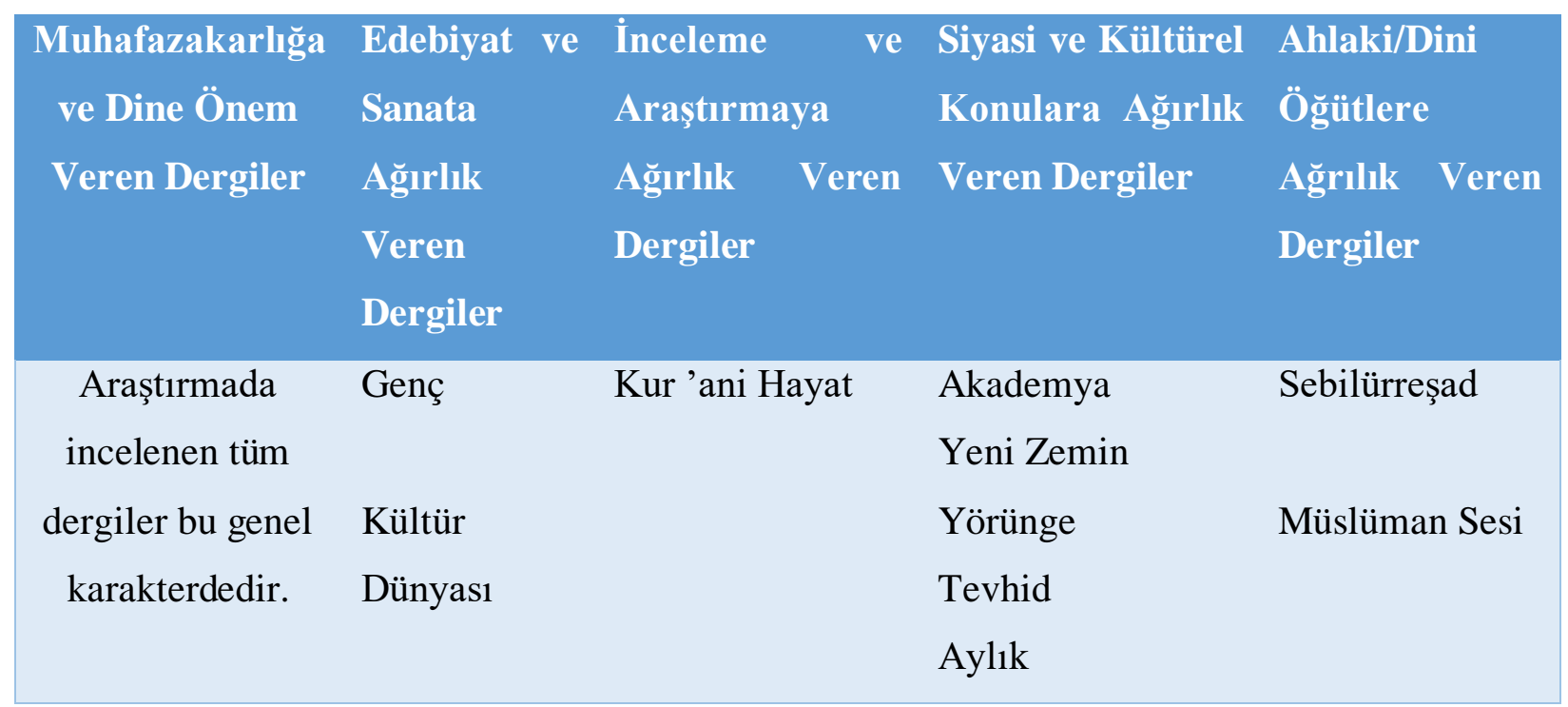

Dergiler hakkındaki genel bilgilere bakıldığında tüm dergilerin ortak özelliğinin dini veya İslami kökenli dergiler olmasından dolayı "Muhafazakarlı̆ga ve Dine Önem Veren Dergiler" diye tüm dergiler vasıflandırılmıştır. Araştırmamızdaki asıl önemli olan nokta ise "alt" özelliklerine göre dergilerin çeşitli şekilde ayrılmasıdır. Bir derginin diğer yazılarında neredeyse tüm sayılarında siyasi haber veya dinî ve ilmi araştırmalara ağırlık vermeyip daha çok gençlere ve edebiyat meraklılarına yönelik muhafazakarlığa ve dine önem veren dergiler "Edebiyata ve Sanata Ağırlık Veren Dergiler" alt özelliğinde birleştirilmiştir. Eğer bir dergide sadece dinî ve ahlakî araştırmalara ağırlık verip hiçbir zaman siyasi ve sanatsal konulara yer vermeyen dergiler ise "İnceleme ve Araştırmaya Ağırlık Veren Dergiler” alt başlığında konumlandırılmıştır. Bu alt başlıkta sadece "Kur'anî Hayat" dergisi bulunmaktadır. Öte yandan dinî ve ahlaki konuları inceleyen ve okuyucusuna aynı zaman da dönemin siyasi aktörlerine öğütler vererek vaaz türünde yazılar yazmayı amaçlayan dergiler ise "Ahlaki/Dini Öğütlere Ağırlık Veren Dergiler" olarak 


\section{Bazı İslami Dergiler Örnekleminde Carl Gustav Jung: Nitel Bir Araştırma}

adlandırılmıştır. Bu alt özelliğe "Müslüman Sesi ve Sebilürreşad” dergileri sahiptir. Çünkü bu dergiler dini ve ahlaki konuları sadece okuyucusuna anlatmakla kalmamış dönemin siyasilerine de ulaşmaya çalışmışlardır. Siyasi iktidarı sert eleştiren ve karşısına almayı amaçlayan bir yapıları yoktur. Fakat "Siyasi ve Kültürel Konulara Ağırlık Veren” dergiler ise siyasileri ve rejimi eleştirmek hedefi ile muhafazakârlığa ve dine ait yayınlar yapmışlardır. Bunlar ise "Akademya, Tevhid, Yeni Zemin, Yörünge ve Aylık dergileridir.

\section{Araştırmada incelenen İslami Dergilerin Ele Aldığı Jung’un Kavramları:}

Bu alt özelliklere ayrılan dergilerin Jung'a bakışları ve onun görüşlerini ele alış tarzları ve amaçları birbirinden farklı olmaktadır. Araştırmanın alt problemlerinden olan "Araştırmada incelenen İslami dergiler Jung'un hangi kavramlarını kullanmayı tercih etmişlerdir?"” sorusuna dergilerin Tablo-1'deki yayın tarihleri sırası ile cevap aranacaktır.

İlk eski dergi olan ve "ahlaki ve dinî öğütlere ağırlık veren” "Sebilürreşad” dergisi Mehtar'ın tercüme yazısında Jung’un arketiplerden saydığ “ “din” hakkındaki olumlu görüşlerini ele almıştır. “Dinin olumlu terapik" etkisine vurgu yapmaktadır.

“Ahlaki ve dinî öğütlere ağırlık veren” diğer bir dergi olan "Müslüman Sesi” dergisinde Jung'un birçok görüşü ele alınmıştır. Özellikle Balaban Jung’un birçok görüşünü yazılarının amacı doğrultusunda kullanmıştır. Balaban, Jung’un görüşlerinden istifade etmiştir: "Bilinç, kişisel bilinçaltı, kolektif bilinçaltı, arketipler, zıtlıklar, din ve Tanrı arketipleri, din ve Tanrı hakkındaki olumlu görüşleri’. Hilali Durukan ise Jung'un görüşlerine değinirken Balaban'ın 1953'te yazdığ1 görüşlerini aynen aşırarak almıştır ve kaynakça vermemiştir. Hem Hilali Durukan hem de yazarı belli olmayan yazılar, Jung’un din ve Tanrı hakkındaki olumlu görüşlerine değinmiştir.

“Siyasi ve kültürel konulara ağırlık veren” dergilerden olan “Tevhid” dergisi Jung’un “bilinç dışı”, “din ve Tanrı" hakkındaki olumlu görüşlerini kullanmıştır. "Yörünge” dergisi ise "Din ve Psikoloji” başlıklı Türkçe'ye tercüme edilen kitabını kısaca tanıtırken Jung’un görüşlerini anlatmak yerine Jung’un bilim dünyasındaki yerini ve ortaya koyduğu görüşlerini sıralamıştır. Buna göre Jung’un psikolojiye katkıları "arketipler”, “kolektif bilinçaltı”, içedönüklükdışadönüklük" ve "kelime çağrışım testleridir". "Akademya" Dergisi, "Yörünge" ile "Yeni Zemin" dergisi tarafindan olumlu bir şekilde tanıtılan "Din ve Psikoloji" adlı kitabı üzerinden 
Jung'u hem Batılı dinsiz psikologlardan ayrı tutar hem de "kolektif bilinçdışı", din, Tanrı" görüşlerini sorgular.

"Siyasi ve kültürel konulara ağırlık veren" dergilerin sonuncusu olan "Aylı"” dergisinin yazılarından tarihsel olarak ilki "Sayı Rüyalarının Anlamı Üzerine" olup burada Jung'un "bilinçaltına" dalarak rüya tahlillerine yer vermiştir. Aylık dergisi Güleç tarafindan yazılan diğer bir yazısında da Jung'un rüya anlayışı ve "şuuraltı" görüşlerine yer vermektedir. Aylık dergisi Şenel tarafından yazılan Fawer'in romanının eleştirisinde Jung'un "kolektif şuuraltı" kavramından bahsetmektedir. Araştırmadaki Aylık dergisinin son yazısında Franz'ın yazısı tercüme edilmiştir. Bu yazıda Jung'un "kolektif şuurdışı”, “arketip”, “eş zamanlılık”, “undus/mundus” görüşleri ele alınmıştır.

"Edebiyata ve sanata ağırlık veren" dergilerden olan "Kültür Dünyası" dergisi Jung'un "kolektif şuuraltı”, "rüya yorumları", "gölge”, "bilinçdışı”, "Hristiyanlığa ve diğer dinlere bakış açısı” gibi konuları ele almıştır. "Genç" dergisi ise 2007'deki yazısında Jung'un din anlayışını ve dinleri psikoterapik kabul ettiği özelliğinden bahsetmekte iken, Kaplan'ın Batıllıları eleştiren 2015'teki yazısında ise Jung'un İslam dinine olumlu yaklaşarak Hristiyan dünyasını eleştiren görüşünü kullanmaktadır.

Kur'ani Hayat dergisinde ise Jung'un "Kehf" suresine dair analizleri ile başlayan yazısında İslamoğlu tarafından bazı eleştiriler ve övgüler birlikte gelmiştir. Dergide Jung'un "kişilik tipolojileri”, "arketipler", "ezdad yani zıtlık" görüşleri anlatılmıştır.

Yukarıda bahsi geçen dergilerde hangi kavramların kullanıldığını gösteren bir tablo oluşturulmuştur (bkz. Tablo-3). Bu tabloya göre dergiler tarafından Jung'un "kolektif bilinçdışı" kavramı en çok kullanılmıştır. Ayrıca Tablo-3'te "Akademya" dergisi hariç tüm dergilerin kullandıkları Jung'un görüşlerine olumlu yaklaştıkları için bu dergilere "+" işareti kullanılmıştır. Ancak Akademya dergisi için “+/-" kullanılmasının nedeni Jung'un bu görüşlerine eleştirel bakıp kısmen olumlu yaklaşmasıdır. Araştırmaya katılan dergilerin hepsi Jung'un "persona”, “animaanimus" ve "self" kavramlarına hiç yer vermemişlerdir. 
Tablo-3 Araştırmada İncelenen İslami Dergilerin Ele Aldığı Jung Kavramlanı

\begin{tabular}{|c|c|c|c|c|c|c|c|c|c|c|}
\hline $\begin{array}{l}\text { Dergiler/ } \\
\text { Jung'un } \\
\text { Kavraml } \\
\text { arı }\end{array}$ & $\begin{array}{l}\text { Sebilü } \\
\text { r- } \\
\text { reşad }\end{array}$ & $\begin{array}{l}\text { Müslüma } \\
\text { n Sesi }\end{array}$ & $\begin{array}{l}\text { Tevhi } \\
\text { d }\end{array}$ & $\begin{array}{l}\text { Yeni } \\
\text { Zem } \\
\text { in }\end{array}$ & $\begin{array}{l}\text { Yörün } \\
\text { ge }\end{array}$ & $\begin{array}{l}\text { Akade } \\
\text { mya }\end{array}$ & $\begin{array}{l}\text { Ayl1 } \\
\text { k }\end{array}$ & $\begin{array}{l}\text { Kültür } \\
\text { Düny } \\
\text { as1 }\end{array}$ & $\begin{array}{l}\text { Gen } \\
\text { ç }\end{array}$ & $\begin{array}{l}\text { Kur'a } \\
\text { nî } \\
\text { Hayat }\end{array}$ \\
\hline $\begin{array}{l}\text { Bilinç/şu } \\
\text { ur }\end{array}$ & & + & & & & & & & & \\
\hline $\begin{array}{l}\text { Kişisel/f } \\
\text { erdi } \\
\text { Bilinçdış } \\
1\end{array}$ & & + & + & & & & + & + & & \\
\hline $\begin{array}{l}\text { Kolektif } \\
\text { Bilinçdış } \\
1\end{array}$ & & + & + & + & + & + & + & + & & + \\
\hline Arketip & & + & & + & + & & + & & & $+/-$ \\
\hline $\begin{array}{l}\text { Din ve } \\
\text { Tanrı } \\
\text { Arketipi }\end{array}$ & + & + & + & + & + & $+/-$ & & & & + \\
\hline $\begin{array}{l}\text { Hristiyan } \\
\text { lık/Diğer } \\
\text { Dinler }\end{array}$ & & & & & & & & + & & \\
\hline $\begin{array}{l}\text { Psikotera } \\
\text { pik Din } \\
\text { ve Tanrı }\end{array}$ & + & + & & & & $+/-$ & & & + & + \\
\hline $\begin{array}{l}\text { Zitlik/Ez } \\
\text { dad } \\
\text { (Komple } \\
\text { ks) }\end{array}$ & & + & & & & $+/-$ & & & & $+/-$ \\
\hline $\begin{array}{l}\text { Kişilik } \\
\text { Tipoloji }\end{array}$ & & & & + & + & $+/-$ & & & & + \\
\hline
\end{tabular}




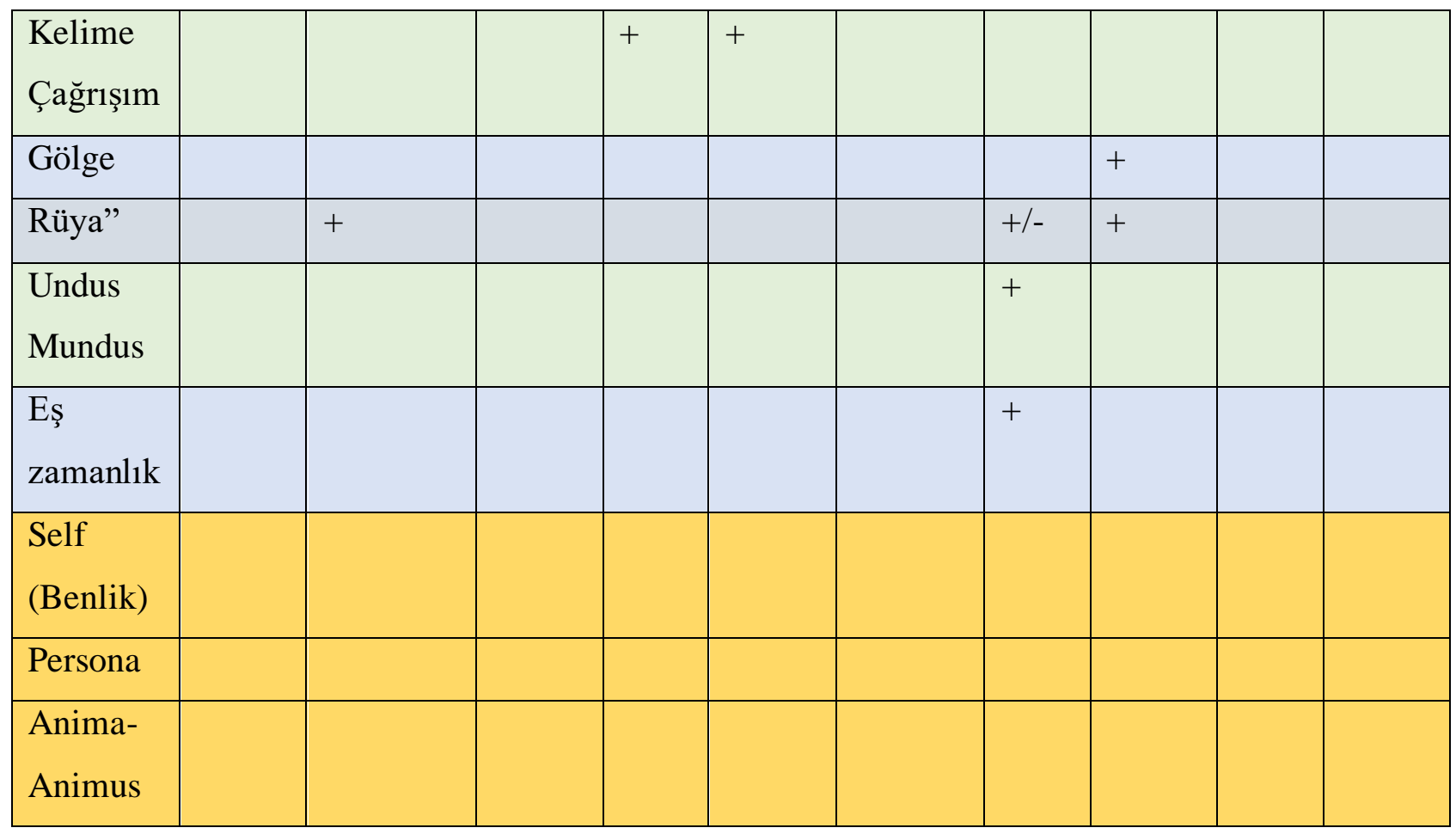

\section{2. “Araştırmada İncelenen İslami dergilerin Jung ve Onun Görüşlerini Kullanma Amaçları:}

Araştırmanın ikinci alt problemi olan "Araştırmada incelenen İslami dergiler hangi amaçlar için Jung'u ve onun görüşlerini kullanmışlardır? ” sorusuna aşağıda cevap verilmeye çalışılmıştır.

$\mathrm{Bu}$ alt probleme çeşitli cevaplar verilebilir. Bu cevaplar, Tablo-2'de dergilerin genel ve alt özelliklerine göre değişmektedir. Söz konusu cevaplar, alt başlıklar altında sunulacaktır. İlk olarak,

\section{a. Jung'un Otoritesine İşaret Ederek İddiaları Kuvvetlendirmek:}

Sebilürreşad dergisindeki Mehtar'ın “Din ve İlim” yazısını bu başlık altında verebiliriz. Çünkü Mehtar, yaşadığı dönemdeki ilmî ve maddî gelişmelere rağmen toplumsal ve bireysel sorunların azalmadığını aksine arttığını bunun sebebinin de dinden uzaklaşmak olduğunu anlatır. Mehtar "Hayatın esaslı maksatlarını hedef tutan, insana hakikati öğreten, yaratıllşındaki yüksek manayı ona anlatan sadece dindir." diyerek din ile bir iddiada bulunmuştur (İddiada Bulunma= İ.B.). Bu iddiasını boş yere demediğini ve yıllarca edindiği tecrübesine de dayandırdığını ima eder: "Son 30 sene boyunca dünyadaki birçok insan ve toplumları gözlemledim " (İddiayı Temellendirme= İ.T.) 


\section{Bazı İslami Dergiler Örnekleminde Carl Gustav Jung: Nitel Bir Araştırma}

diyen Mehtar, din ile ilgili iddialarını kuvvetlendirmek için Jung'un kitabının adını da yazarak (O.İ.) insan ve toplumlar için “dinin psikoterapik” olduğunu aktarır (Otoritesine İşaret ederek İddiasını Kuvvetlendirme= O.İ.K.).

Mehtar, "30 yıllık edindiği tecrübesine dayanarak (İ.T.) dinin, toplum ve insan için faydalı olduğu iddiasını (İ.B.) "kuvvetlendirmek” için Jung’un kitabının adını yazarak “otoritesine” işaret etmiş (O.İ.) ve “dinin psikoterapik” olduğu konusunda Jung’u kullanmıştır (O.İ.İ.K.).

Müslüman Sesi dergisinde Balaban'ın yazılarında da benzer durumlar vardır. Balaban'ın Müslüman Sesi dergisindeki yazı silsilesi içindeki ilk yazısında "jung’un otoritesine işaret ederek iddialarını kuvvetlendirdiğini” rahatlıkla görebiliriz. 26 Ocak 1949 tarihli “İnsan İki Taraflı Aynadır” adlı yazısının 4. Sayfasının ilk paragrafında Balaban Jung'un kitabını yazarak otoritesine şöyle işaret etmektedir: “Bu yazı bugünkü psikolojinin bayraktarlarından Zürih'li Yung'un “Wirklichkeit Seel” (Ruhun Gerçekliği) adlı eserinden özetlendi” (O.İ.). Bununla da yetinmez, Balaban, "Yeni psikolojideki feyizli mesaisine karşı ... dünya üniversitelerinin en büyüklerinden on biri fahri doktorluk payesi vermişlerdir. Alman akademisiyle İngiliz akademisinin azasıdır. İsviçre pratik psikoloji derneğinin reisi olup Zürih'te profesördür” gibi çok uzun ve öznel ifadelerle Jung'un otoritesine işaret etmiştir (O.İ.). Daha sonra Balaban, çeşitli konulara değindiği yazısında “insanların özünde birbirine benzediği”, “din yoksa insan yarımdır”, "bugünkü psikoloji eğitimi ruhsuzdur” (İ.B.) gibi iddialarını, İbrahim Hakkı'nın Marifet-namesinden bir şiiri yazarak, rüyaların bazen doğru çıktığını söyleyerek ve çeşitli mantıki akıl yürütmeler de kullanarak temellendirir (İ.T.). Balaban temellendirdiği iddialarını Jung’un "kolektif bilinçdışı”, “insan psişesi” gibi görüşlerinin "Wirklichkeit Seel” kitabından uzun anlatımlar yaparak kuvvetlendirmiştir (O.İ.I.K.).

Balaban, (1949b), 30 Aralık 1949 ile 7 Aralık 1949, cilt 2 ve sayı 20'de "Ínsanın Aslı ve Görevi Hakkında- (Yung) ile İslam Tasavvufu arasındaki Görüş Birliği”" adlı yazılarında "Kâinat, alem-i kübra iken, insan, alem-i suğradır”, "insan ruhunun derinliklerinde din ve Tanrı inancı vardır” ve “tasavvuf geleneği ile Jung'un görüşlerinin birbirine benzer”, “insan, cami’ül-ezdad yani hayvanlık-insanlık karmasıdır”, "insan, fanilik libası içinde ebediyet yolcusudur” iddialarını (İ.B.) temellendirmek için “çeşitli tasavvufî görüşlere, Hz. Muhammed'e ait "ilk yaratılan benim ruhumdur” hadisine ve Hz. Davud'a, Yunus Emre'ye Niyaz-i Misri'ye, Bursali İsmail Hakkı'ya, Erzurumlu İbrahim Hakkı'ya, Efezli Heraklit'e ait çeşitli anlatılar ve şiirlerden alıntı yapar. Her 
iki yazısında da bu temellendirdiği iddialarını anlatmaya başlamadan önce "Bugünkü psikoloji ilminde bir (ekol=mezhep) sahibi olan Zürihli (Yung) a ..." diyerek Jung'un otoritesine işaret etmiştir (O.İ.). Her iki yazıda da "temellendirdiği iddialarını", "otoritesine işaret ettiği Jung'un "bilinç, bilinçdışı, kolektif bilindışı, arketip, kişilikte kompleks/zıtllk ve kompleks ile ilgili ontogenetik-filogenetik psikolojiler" ve "psikoterapik din ve Tanrı" görüşlerini kendi üslubu içinde anlatarak kuvvetlendirir (O.İ.İ.K.).

Balaban, 12 Ağustos 1950 ve 22 Ocak 1951 tarihlerinde “Tanrı kitabından: ..." başlıklı yazılarında sırasıyla "sapıklara uymayalım" ve "din ve iman fitrîdir, insan için önemlidir" diyerek çeşitli iddialarda bulunur (İ.B.). Bu iddialarını temellendirdiği En'am Suresi Ayet 116 ile Rum Suresi Ayet 30'un meallerini başta vererek yazılarına başlar (İ.T.). Jung'un otoritesine işaret ettiği birinci yazısında "Bugünkü yeni psikolojiyi kuranlardan Zürihli profesör (Yung)" ile ikinci yazısında "Zürihli profesör (Yung)” (O.İ.) ifadeleri ile başlayarak Jung'un "din ve Tanrı arketipi” ile "psikoterapik din ve Tanrı" görüşlerini anlatarak temellendirdiği iddialarını kuvvetlendirmeye çalışmıştır (O.İ.İ.K.).

Balaban, 11 Nisan 1952 tarihli "Din ve Terbiye" ve 3 Mayıs 1952 tarihli "Din ve Terbiye 2" başlıklı yazılarında "eğitim ve terbiye için din önemlidir", "din ve Tanrı duygusu fitrîdir", “Atatürk'ün modernleşme hamlelerini din terbiyesi ile tamamlamak" iddialarını (İ.B.), Hilmi Ziya Ülken'in 1952'deki Yeni Sabah yazısından ve Ziya Gökalp'in 1918'de yazılan “Türkleşmek, İslamlaşmak ve Muasırlaşmak" kitabından ve Rum Suresi 30. ayetten alıntılar yaparak temellendirir (İ.T.). Bu temellendirdiği iddialarını Jung'un otoritesini göstermek için "Zürihli büyük psikolog Yung’a göre” diyerek (O.İ.) “din ve Tanrı arkepi” ile "psikoterapik din ve Tanrı" görüşleri ile kuvvetlendirir (O.İ.İ.K.).

Balaban'1n 17 Haziran 1952, 4 Aralık 1952 ve 18 Temmuz 1953 tarihli yazılarında da aynı durumu görebiliriz. Bu yazılarında "din ahlaktan ibarettir", "ahlak Tanrı'ya, topluma, kendimize vazifedir", "din sadece öte dünya için değil bu dünyada da sıhhatimiz için gereklidir", "kişi ve toplum için din önemlidir", "iman ile Allah'ın kucağına atılırız” iddialarında bulunur (İ.B.). Bu iddialarını temellendirmek için "Hz. Muhammet der ki” diye başlayan hadislere, Tin Suresi 4-6 ile Haşir Suresi 19. Ayetlerine, Niyazi Mısri'den, Adanalı İsmail Emre'den, Mevlana'dan Yunus Emre'den alınan bir şiirlere, Semih'a Ayverdi'nin kitabına ve Hilmi Ziya Ülken'in Yeni Sabah'taki yazısına ve Bakırköy akıl hastanesi başhekimi Fahri Celal'in gazete haberlerine 


\section{Bazı İslami Dergiler Örnekleminde Carl Gustav Jung: Nitel Bir Araştırma}

dayanarak temellendirir (İ.T.). Bu temellendirdiği iddialarını "Zürihli Yung” veya “Zürihli büyük ruhiyatçı doktor Yung" diyerek Jung'un otoritesine işaret eder (O.İ.) ve Jung'un "din ve Tanrı arketipi", "psikoterapik din ve Tanrı" görüşlerini anlatarak kuvvetlendirir (O.İ.I.K).

Müslüman Sesi dergisinin diğer yazarlarından olan Hilali Durukan'ın “Din ve İman-5” başlıklı yazısı Balaban'ın 18 Temmuz 1953’teki yazının intihali olduğu için burada tekrar analiz etmeye ihtiyaç duymamaktayız. Durukan'ın yazısında da Jung'un otoritesine işaret ederek iddialarını kuvvetlendirme amacı bulunmaktadır diyebiliriz. Müslüman Sesi dergisinin yazarı belli olmayan iki yazıda da Jung aynı amaçla kullanılmıştır. 8 Kasım 1951 tarihli “Son Nefeste Tanrı'ya Dönüş” yazısında din ve iman duygusunun insan için önemli olduğu iddiasını (İ.B.) Nazi şeflerinden birinin idam sephasında yaşadığı duygularla temellendirir (İ.T.) ve "Zürihli ruhiyatçı (Yunga) göre diyerek Jung'un otoritesine işaret eder (O.İ.). Jung'un "psikoterapik Din ve Tanrı” görüşünü kullanarak temellendirdiği iddiasını kuvvetlendirir (O.İ.İ.K.). Derginin "Ahlakı Kökleştiren Dindir” yazısında başlıktan da anlaşılacağı üzere "ahlakın din tarafindan kökleşir” iddiası (İ.B.) “Hz. Ali'den, Kuran'dan alıntı", Hanry Ford'tan alıntı yaparak temellendirilmiştir (İ.T.). “Avrupa'nın en büyük profesörlerinden (Yung) diyor ki” diyerek Jung'un Otoritesine işaret ediyor (O.İ.). Jung'un şu sözünü kaynak göstermeden verir: "Dünyada her iyilik mutlak imandan doğar. Bunun gibi her kötülük de imansızlıktan gelir”. Jung'a isnat ettiği bu sözü ile temellendirdiği iddialarını Jung'un otoritesine işaret ederek kuvvetlendirmeyi amaçlar. (O.İ.I.K.).

Kültür Dünyası dergisinin Armağan tarafından yazılan Ekim 1997 tarihli yazısı da Jung’u aynı şekilde kullanmıştır. Armağan bu yazısındaki iddiası Hristiyan Batı'nın İslamiyet'in her an ortaya çıkmasını istemez ve İslam Batı için korkulu bir rüya olmuştur iddiasında bulunur (İ.B.). Armağan, bu iddiasını temellendirmek için Jung'un İspanya'nın Toledo şehrinde yaşayan Fransız bir hastasının gördüğü rüyayı anlatarak rüyadaki yılan, yeraltı, bastırma eylemi, mağara, korku, hançer, kupa gibi imgeler İslamiyet'in Batıdaki imgeleriyle örtüştüğünü söyler (İ.T.). Armağan, Jung'un otoritesine işaret için "psikanalizin bir diğer babası" ifadesini ve rüya tahlilindeki ustalığını göstermektedir (O.İ.). Armağan temellendirdiği iddialarını Jung'un rüya yorumları sonucunda ileri sürdüğü "Hristiyan dünyasının bilinçaltı", "gölge", "bilinçdışı", "kolektif bilinçdışı” hakkındaki görüşünü anlatarak kuvvetlendirmiştir (O.İ.İ.K).

Genç dergisinin 2007'de 11. Sayısındaki Yazıcılar tarafından kaleme alınan "Kendi İçimde Boğuluyorum” adlı yazısında “dinin insanın psikolojisi için önemlidir” iddiasını (İ.B.) 
temellendirmek için yani dinin önemli olduğunu somut bir olayla göstermek için, bir gencin psikoloji internet sitesine yazdığı psikolojik sıkıntısını "kendi içimde boğuluyorum" ifadesini kullanarak anlatır. Dinden uzaklaşan modern psikolojinin bu gibi gençlere çare olamamasını eleştirir (İ.T.). Jung’un otoritesine dair "diğer Batılı din karşıtı olmayan Batılı bir psikolog” (O.İ.) diyen Yazıcılar temellendirdiği iddialarını, Jung'un "psikoterapik din ve Tanrı" hakkındaki görüşünden alıntı yaparak kuvvetlendirmiştir (O.İ.İ.K.).

Genç dergisinin 2015 tarihli Kaplan tarafından yazılan "Batı'nın İslam Düşmanlığının Kısa Bir Arkeolojisi” adlı yazıda "Batı Müslümanlara ön yargılıdırlar, düşmandırlar, sevmezler, nefret ederler" iddiasında bulunur (İ.B.). Bu iddialarını temellendirme için İslam Tarihinden somut örnekler vererek Haçlı seferlerinin yapılmasının nedenini İslam'ın hızla dünyada yayılmasını engellemek ile ilgili bilgiler verir (İ.T.). İslam medeniyet tarihinin tarihi yolculuğu enfüsle/dikey eksenle afak/yatay eksen arasındaki medcezir, gidiş-geliş, akış-bakış hareketi (İ.B.) olup bu hareketi Batı elbette istemez der Kaplan (İ.T.). Kaplan, temellendirdiği iddialarından sonra "çağın büyük psikanalizlerinden Carl Gustav Jung” diyerek Jung'un otoritesine işaret etmiştir (O.İ.). Son olarak, Kaplan, iddialarını kuvvetlendirmek için Jung'un "Hristiyanlık” hakkındaki eleştirel görüşlerine baş vurmuştur (O.İ.I.K).

\section{b. Bir Yönüne Dikkat Çekip Hedef Kitlesini Yönlendirmek İçin Jung’u Kullanmak:}

Bu başlık altında, bazı İslami dergilerin Jung'un belli bir yönüne (mesela, eleştirilecek yönüne, okunması tavsiye edilen bir kitabına, bazen bilimsel derinliğine bazen Jung'un Batılı emsallerinden farklı olduğuna veya İslami düşünceye daha yakın olduğuna) dikkat çekerek hedef kitlelerinin Jung algısını yönlendirmek için Jung’u kullandıkları gösterilmeye çalışılacaktır. Buna göre;

Tevhid dergisinin 8 Ocak 1979'daki yazarı belli olmayan "Ruhi Hayatta Şuuraltı” başlıklı yazısı derginin hedef kitlesini ve hatta siyasi bir lideri yönlendirme amacı taşıdığını göstermektedir. Tevhid dergisinin bu yazısında Jung'un Türkçeye çevrilen kitabının okunmasını tavsiye eder $($ Kitlesine Tavsiye= K.T.). Sonra kitabı okurken okuyucularının eleştirdikleri iki konuda dikkatli olmalarına işaret eder: ("La şuur" yerine "şuur altı" olarak kabul etmesini ve Tanrı ifadelerini de Allah ifadesi olarak görmelerini tavsiye eder (Eleştiriye Dikkat= E.D.). Ayrıca dergi Jung'un Freud'dan farklı olduğunu da dile getirmektedir (Emsallerinde Farklı Kabul etmek=E.F.K.). Tevhid dergisi bu yazısında siyasi bir kişilik olan Ecevit'i bile hedef kitlesi sayarak Jung'u ve Jung 


\section{Bazı İslami Dergiler Örnekleminde Carl Gustav Jung: Nitel Bir Araştırma}

hakkındaki bu yazının siyasi bir kişilik olan Ecevit ve Ecevit'in temsil ettiği kitle tarafından bile okunmasını istemektedir (K.T.).

Kısacası Tevhid dergisi hedef kitlesi olan okuyucularına (K.T.) ve siyasi hedef saydı̆̆ı Ecevit ile kitlesine (K.T.), emsallerinden farklı kabul ettiği (E.F.K.) Jung’un “şuur dışı”, "ahlak anlayışı”, “inanmanın gerekliliği” görüşlerini anlatan tercüme kitabını yaptığı eleştiriler dikkate alınarak (E.D.) okunmasını tavsiye ederek kullanmıştır (Hedef Kitlesini Yönlendirerek Kullanma= H.K.Y.K).

Yörünge dergisi ile Yeni Zemin dergileri, Mart 1994 tarihli "Din ve Psikoloji” başlıklı kitap tanıtımında da hedef kitlesini yönlendirerek Jung'u kullanmıştır. Çünkü Jung’un Türkçeye çevrilen kitabını tanıtırken bilimsel derinliğine dikkat çekerek (Bilimsel derinliğine dikkat çekerek=B.D.D.Ç.) Jung'un birçok disiplinde çalışmalar yürüttüğünü bu çalışmalardan geriye çok zengin ve renkli tablonun kaldığını ve çalışmalarının anlaşılmasının güç olduğunu (Eleştiriye Dikkat= E.D.), bunun için sabır ve dikkatle birçok kez okunarak Jung'un anlaşılabileceğini anlatarak Jung'u hedef kitlesine tavsiye etmiştir (K.T.). Ayrıca Yeni Zemin “... diğer psikanalizlerden farklı ..." diyerek Jung'u emsallerinden farklı kabul etmiştir (E.F.K.). Yeni Zemin ve Yörünge dergileri Jung'u herhangi bir siyasi hedef için veya eleştiriye tutmadığı için Tevhid dergisi gibi Jung’u kullanan dergilerden farklı olarak Jung’u tavsiye etmiştir.

Kısacası Yeni Zemin ve Yörünge dergileri, “... diğer psikanalizlerden farklı ...” kabul ettikleri Jung'u emsallerinden farklı kabul etmiş (E.F.K.), Jung'un 'bilimsel derinliğine dikkat çekip (B.D.D.Ç.) onu anlamak için sıkça okunmasını tavsiye (Kitlesine Tavsiye= K.T.) ile Jung'u “Hedef Kitlesine Yönlendirerek Kullanmıştır” (H.K.Y.K.).

Akademya dergisi ise Tevhid dergisine benzer şekilde Jung'u kullanmıştır. Akademya dergisi de Yörünge ve Yeni Zemin dergisi gibi Jung’un Türkçeye çevrilen “Din ve Psikoloji” kitabını ele alır ama üslup Tevhid dergisi gibidir. Ağustos 1998 tarihli ve Oymak tarafindan yazılan "Carl Gustav Jung ve Din” başlıklı yazıda ilk olarak, Jung'un o çağdaki ruha inanmayan ruhiyatçı emsallerinden farklı olduğunu kabul eder (E.F.K.). Sonra okuyucu kitlesine Jung hakkında getirdiği eleştirilere dikkat çeker (E.D.). Tevhid dergisindeki gibi siyasi hedefi yönlendirme yerine kendi ideolojisini beğenen kitleyi yönlendirme yaparak jung’u kullanmıştır. Mesela, İBDA fikriyatında yer alan “kolektif bilinçdışı” kavramını Avrupa’ya kazandıran ilk kişi olarak jung’u kullanması (E.F.K.) ve İBDA diyalektiğinde bulunan “zıtlıkların birliği” gibi vb. kavramlarda hakikati tutturması 
(K.T.) ama "Hak din” ve “Allah” inancında muğlak bir düşünceye sahip olabileceğinden (E.D.) ve tercüme edenin Jung'un görüşlerini Türkçeye tam yansıtamayacağından Jung'u okuyacak olan hedef kitlesinin dikkatli olmasını tavsiye eder (E.D.).

Kısacası Akademya dergisi, emsallerinden farklı kabul ettiği (E.F.K.) Jung'u okumayı tavsiye etmiş (K.T.) ama İBDA geleneğine bağlı hedef kitlesine İBDA geleneğinin dikkat çektiği eleştiriler (E.D.) çerçevesince okunmasını tavsiye ederek (K.T.), Jung’u ve onun görüşlerini kullanmıştır (Hedef Kitlesini Yönlendirerek Kullanma= H.K.Y.K).

Aylık dergisinin Aralık 2016 tarihli Güleç tarafından yazılan yazıda Batı bilim dünyasının her şey el attığı halde her şeyi yüzeysel bıraktığı gibi rüyaya da el atmış ama rüyayı da yüzeysel bıraktığını anlatarak Batı'yı, batılı psikologları ve Jung'u da eleştirir (E.D.). Güleç, hedef kitlesini şöyle yönlendirerek Jung'u kullanır: Jung'un emsallerinden farklı olarak bir fizikçi titizliğinde sistematik olarak rüyaları kaydeden (E.F.K.) Jung, rüyaları "şuur altı" olarak yorumlaması olumlu da olsa (K.T.), bazen rüyaları dogmatik ele alması ve mitleştirmiş olması eleştirilmelidir (E.D.). Rüya konusunda Güleç, İBDA geleneğinin lideri Mirzabeyoğlu'nun rüya üzerindeki çalışmalarını tavsiye ederek (K.T.) Batı'nın ve Jung'un rüya konusundaki fikirlerini sorgular (E.D.).

Kısacası, Güleç, rüyaları "şuur altı" olarak yorumlaması olumlu olsa da (K.T.), Jung'u yazısında Batılılar arasında rüya konusunda titiz çalışmaları olsa da (E.F.K.), Jung'un rüyayı İBDA hareketinin lideri kadar anlamadığını iddia edip (E.D.) hedef kitlesini yönlendirerek Jung'u kullanmıştır (H.K.Y.K).

Aylık dergisinin Şubat 2009 tarihli Şenel tarafından yazılan yazıda, Adam Fawer'in romanının eleştirisinde, İBDA anlayışıyla uyumlu olan Jung'un "kolektif bilinçdışı” kavramının (K.T.) evrim için kullanılmasını eleştirir (E.D.). Hedef kitlesini İBDA hareketinin liderinin düşüncelerine dikkat çekerek (E.D.) hedef kitlesini yönlendiriyor ve Jung'un "kolektif bilinçdışının" evrim ile kullanılmamasını tavsiye ederek (H.K.Y.K) hedef kitlesini yönlendiriyor.

Aylık dergisinin Şubat 2008 tarihli Franz'ın tercümesi ile Jung'un psikolojiye kattığı kavramların tabiat bilimlerine aktarılması üzerine yazılmıştır. Aylık dergisi hedef kitlesini özellikle "kolektif bilinçdışı" ve "arketip" kavramları tabiat bilimlerine ve biyolojiye aktarılarak bakılmasını tavsiye ederken (K.T.) özellikle biyolojide ve evrimdeki ihtimal anlayışının ortaya çıkardı̆̆ı tutarsızlıklara ve eleştirilere dikkat çeker (E.D.). Batı ve bilim dünyası içinde sadece Jung'un "kolektif bilinçdışı" 
ve "undus mundus" kavramlarının bilimdeki tutarsızlıkları giderebileceğinden (E.F.K.) ve birçok ferde daha dürüst daha ahlaklı daha bilinçli bir tavır sağlayacağından dolayı Jung'un görüşlerinin değerli olduğunu kabul ederek (E.F.K.) hedef kitlesini Jung hakkında yönlendirmektedir (H.K.Y.K.).

Kur'an-î Hayat dergisinin İslamoğlu'na ait Şubat 2015 tarihli yazısı da Jung'un emsallerinden farklı olduğuna ve eleştirilere dikkat çekerek Jung hakkında hedef kitlesini yönlendirerek kullandığını göstermektedir. İslamoğlu hedef kitlesini yönlendirirken Jung'un 'Kur'an'da tutarsızlık” görüşünü dile getirdiği için eleştirilmesi gerektiğine dikkat çekiyor (E.D.). Ancak İslamoğlu’na göre “Batılı bir insandan Kur'an'a ait bir sürenin tefsirine ilişkin yorum getirmesi ve (Freud gibi) emsallerine göre daha beterlerinin olduğu (E.F.K.) düşünülürse Jung garipsenmemelidir”. Jung'un kişilik tipolojilerinden gerektiğinde kullanılmasını kendi kitlesi olan Akabe Eğitim Üst Kurulu'na ve okuyucularına tavsiye eder (K.T.).

Kısacası İslamoğlu, emsallerinden farklı olan (E.F.K.) Jung’un eleştirilecek yönlerinin olmasına (E.D.) rağmen, "kişilik tipolojileri gibi işe yarayan görüşlerini alarak" Jung’tan istifade edilebileceğini tavsiye edip (K.T.) Jung'u "Hedef Kitlesini Yönlendirerek Kullanmıştır" (H.K.Y.K.).

\section{3. İslami Dergilerin Jung’a ve Jung'un Görüşlerine Yönelik (Övücü ve Eleştirel) Yargıları:}

Araştırmada analiz edilen dergilerin Jung’a ve Jung’un görüşlerine yönelik övücü ve eleştirel yargıları bulunmaktadır. $\mathrm{Bu}$ övücü ve eleştirel yargılar, dergiler tarafından "iddialarını kuvvetlendirirken" ve "kitlesini yönlendirirken" kullanılmıştır. Yukarıda bununla ilgili bilgiler verilmişse de bu konu derli toplu bir şekilde bu başlık altında verilecektir. Buna göre;

\section{Jung'un bizzat şahsına, kariyerine ve bazı görüşlerine yönelik övücü yargılar şunlardır:}

Sebilürreşad Dergisi: Jung'un ne kadar değerli olduğunu yazının geneli ile karşılaştırıldığında anlaşılmaktadır. Koyu ve kalın harflerle Jung'un kitabının adını yazdıktan sonra tırnak içinde ve yeni bir paragraf halinde sunarak Jung’tan alıntı yapılmıştır.

Müslüman Sesi Dergisi: “... psikolojinin bayraktarlarından Zürihli Yung”; “dünya üniversitelerinin on biri fahri doktorluk payesi vermişler.”; “Ísviçre pratik psikoloji derneğinin 
Journal of Social Research and Behavioral Sciences, Volume: 7 Issue: 14 Year: 2021

reisi"; "Zürih'te profesör", "ekol-mezhep sahibi olan Zürihli Yung”; "Zürihli büyük ruhiyatçı doktor"; "Zürihli profesör"; "Zürihli ruhiyatçı Yung"; "Zürihli Yung”.

Yeni Zemin ve Yörünge Dergisi: “... oldukça zengin ve renkli bir tablo bırakmış”; “... eserleri oldukça geniş bir birikimin sonucu olduğu için...”; “... açıklamadan çok anlamaya önem verir..."; "kişinin deneyimine müdahale etmez...”; “... hastanın kendini tanımasına ve yorumlamasına çalışır."

Tevhid Dergisi: “... son yüzyılın büyük ruhiyatçılarından... ”; “...gerçekten düşündürücü ipuçları veren ..."; "Dr. Yung...".

Kültür Dünyası Dergisi: “... psikanaliz ekolünün diğer bir babası ...”.

Genç Dergisi: “... meşhur psikiyatrist...”; “... Jung'un değindiği noktayı içinde hakikat payı taşıdı̆̆ı hasebiyle ...”; “... çağın büyük psikanalizlerinden Carl Gustav Jung ...”.

Akademya Dergisi: “... ruhiyatın .... Ü̧̧ kurucusundan biri addedilen ...”; “... çağının ruha inanmaz ruhiyatçıları içinde, onlardan ayrı bir anlayışı temsil eder."; kolektif şuuraltı gibi .... Hakikati IBDA fikriyatında rastladığımız bir mefhumu Batı ruhiyatına getiren ilk kişidir.”; "Jung, hakikatini IBDA diyalektiğinin gösterdiği "için dişta takibi", "zltların birliği”", "kendinde obje mihrakı" gibi mevzularda hakikate yaklaşması...".

Aylık Dergisi: “...insanlığın ruhi etkinliklerinin araştırılması alanında, Jung'un düşüncelerinin önemli olduğu anlaşılabilir.”; “... laboratuvarda deney yapan fizikçi titizliğinde sistemli kayıtlar yapan ..."; ... izlediği usul rüyaları zaman zaman cisimleştirmeye götürse de ...”.

Kur'ani Hayat Dergisi: “Jung'un arketip tezi bu meselede hayli kullanışll ve çözümleyici görünmekte ...”; “Jung Eflatun'a daha yakın durduğu için bizden biri gibi duruyor.”; “(Jung'u kastederek)... Freud'la klyaslandiğında elbette bir artıdır...”; “... meslektaşı Freud'un şehvet güdüsüne dayalı psikanaliz sistemiyle klyaslanmayacak kadar değerlidir.”; Jung'un metaryalist ve pozitivist Bati psikolojisine alternatif diyebileceğimiz yaklaşımı...”, “Jung'un başarıly tasnif ettiği bu mizaçların ... hepsi de gereklidir.".

\section{Jung'un bizzat şahsına, kariyerine ve bazı görüşlerine yönelik eleştirel yargılar:}

Akademya Dergisi: “Jung'un anlayışında .... "Hak Din” mefhumuna rastlanmaz.”; "Tanrı'ya inanıyor musunuz? sorusuna verdiği cevap "inanmıyorum fakat biliyorum...”; “...benim bildiğim 


\section{Bazı İslami Dergiler Örnekleminde Carl Gustav Jung: Nitel Bir Araştırma}

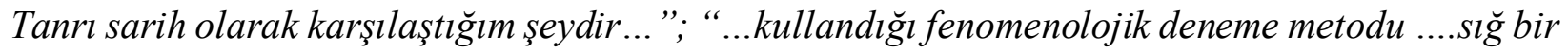
kafa yapısına sahip olduğunu...”; “Onda "Hak Din” diye bir mefhumun bulunmadığını ...”; “... Jung'un kafasında “Allah mı insanı yarattı, insan mı Allah' ' yarattı?” şeklinde bir soru ömür boyu dolaştı.”; “... Mutlak Fikir'den âzâde ilmî yaklaşımı...”; “... mihraksız tümevarım zafiyetiyle karşı karşıya bırakmıştır.”; “... kolayca dinsiz yahut dindar diyemiyoruz Jung’a.”; "Hakikat Bir'de bulunamayınca ....ve Jung kesinkes pay sahibidir bundan."

Aylık Dergisi: “... tekâmül (evrim) teorisindeki tek hücreli canlıdan meydana gelen ilk bebek... efendim bu "kolektif şuurdan" faydalanarak öğreniyormuş ..."; "El attı, ancak işin sathında kaldı...”,; "Rüya bahsinde de ...körün fili tarifi gibi... ”; “... rüya yorumlarında daha çok dogmatik anlayış ve mitler üzerine meyletmiştir.”; “...rüyalarla ...benzerlik gösteren mitleri ön plana çıkarmıştır."

Kur'ani Hayat Dergisi: “...O kendi tezine malzeme arlyor ... uymazsa uyduruyor...”; “...keşke Jung Kur'an'ın şu şu ayetlerini görseydi, tezini kemale ulaştırırdı...”; “...arketipler tezine ...belki de... İslam merakının bir izdüşümü... ”; “Jung çift kutuplulukla zıt kutupluluk arasındaki farkı fark edemediği için ..."; "O tam bir tasnifçi... tasnifler zihni sınırlar...”; "Bir eleştirim de sistemin dilemmaya (dikotomik) dayalı olmast...”; "Ve son ve en büyük eleştirim: Jung’un çözümlemesi "tanıyıcı" olmaktan çok "tanımlayıcı” bir işleve sahip.”; “Jung'un arketipleri bir "TESPİT” değil de bir "TEŞHISS” olarak görülse ne ala...".

\section{4. İslami Dergilerin Jung’a ve Onun Görüşlerine Genel Yaklaşım Tarzları:}

$\mathrm{Bu}$ başlık altında araştırmanın alt problemlerine ilişkin tespit edilen yukarıdaki bulgu ve yorumlar göz önüne alınarak ana problem olarak belirlenen "Íslami Dergilerin Jung'a ve Onun görüşlerine genel yaklaşım tarzı nasıldır?” sorusuna ilişkin çeşitli yorumlar anlatılacaktır.

Araştırmada analizi edilen İslami dergilerin geneli hakkında şunları diyebiliriz: Bu dergilerin hiçbiri, şekil ve format açısından bilimsel dergiler olmadığı açıktır. Yazıları günümüz bilimsel metot ve formatlarına uygun değildir. Bazılarında intihal olduğu görülmektedir (bkz. Müslüman Sesi-Durukan ve Yeni Zemin-Yörünge dergileri). Dergiler, Jung’tan alıntıladıkları bilgileri bazen metin içinde veya sonunda kaynak olarak yazmakta iken bazen hiç yazmamışlardır. Bu dergilerin yazılarının bilimsel bir amaç taşımadıkları görülür. Çünkü tüm dergilerin hedefledikleri belli bir kitlesi olup bu kitlelerini yönlendirme amaçları vardır. Söz konusu kitleleri sadece okuyucu 
anlamında görmemek gerekir. Siyasi veya ideolojik rakipleri de hedef kitleleri arasında olabilir. Bunun için bazen, İslami dergiler siyasi ya da ideolojik rakiplerini de yönlendirmeyi amaçlamışlardır (bkz. Tevhid, 1979).

Buradaki "yönlendirme5" amacını sıradan bilgi verme olarak değil çok daha geniş açıdan görmek gerekir. Çünkü bu dergiler, yönlendirmek istediği rakip ya da taban/dost kitlelerine kendi dinî görüşlerini/ideolojilerini tavsiye edip anlatmak, benimsetmek ve bunların savunucusu veya sempatizanı yapmaktır ki bu yönlendirmenin en nihaî amacı da İslami bir ıslah veya devrim oluşturmaktır. Mesela İran Devrimi'ni savunan Tevhid dergisi ile İslami Büyük Doğu Akıncıları diye bilinen IBDA hareketinin Akademya ve Aylık dergilerini devrimci olarak görebilirken Müslüman Sesi gibi dergiler ise 1slahatçı bir anlayıştadırlar. Müslüman Sesi, dinde reformun olamayacağını, İslam'ın geri kalmışlıkla ilgisinin olmadığını, gerçek İslam'ın rejime ve modern hayata ters düşmediğini, ülkedeki geri kalmışlı̆̆ın sebebinin ise cehalet olduğunu iddia ederek yayın hayatına başlamıştır (İşler, 2018: $52 \mathrm{vd}$.). İster ıslahçı isterse devrimci olsun araştırmadaki tüm dergilerin ortak özelliği "muhafazakarlığa ve dine" önem vermeleridir. Onun için Tablo-2'de tüm dergilerin ortak özelliğinin "muhafazakarlığa ve dine" önem ve öncelik vermek olduğu gösterilmiştir. İdeolojileri ve yayın amaçlanı farklı da olsa araştırmadaki tüm İslami dergiler "Jung'u" kitlelerine yönlendirmişlerdir. Bu yüzden şu sonuca ulaşabiliriz: "Araştırmadaki tüm Íslami dergilerin ortak konusu "Jung'tur". En radikal sayılan devrimci veya siyasi dergilerden tutun da 1lımlı ve 1slahatçı İslami dergiler bile Jung'u yayın hayatlarında işlemişlerdir. Sonuç olarak araştırmadaki tüm dergilerin ortak konusunun/kümesinin “Jung” olduğunu söyleyebiliriz.

Araştırmada incelenen İslami dergilerin ortak konusu Jung ise de Jung'u ve onun görüşlerini ele alış tarzları farklıdır. Her şeyden önce Jung'un psikolojiye katkı sunduğu görüşlerini konu edinmeleri bile farklıdır. Bunun için yukarıdaki Tablo-3'e baktığımızda İslami dergiler Jung'un görüşlerinden her birini ele almamışlardır. Yani Jung’un tüm görüşlerini bütüncül bir şekilde ele almamışlardır. Hatta bazı İslami dergiler ise Jung'un bazı görüşlerini eleştirerek hedef kitlesine anlatmışlardır. Tablo-3’te İBDA'nın yayın organı olan Akademya dergisinin Jung'un 'kolektif

\footnotetext{
5 "Yönlendirme", iletişim sosyolojisi açısından bakıldı̆ı̆ında propaganda olarak görülse de "propaganda" daha çok olumsuz anlam içermektedir (Özer, 2019: 16) ve bazen yıkıcı amaçlarla birtakım yalan iddiaları yaymak olarak da görülür (Tengilimoğlu ve Öztürk, 2004: 32). Jung üzerine yapılan bu araştırmada analiz edilen dergilerin yalanı veya hayali bir şeyi yayma hedeflerinin olmadığı düşünüldüğünden "propaganda" yerine "yönlendirme" ifadesi kullanılmışır.
} 


\section{Bazı İslami Dergiler Örnekleminde Carl Gustav Jung: Nitel Bir Araştırma}

bilinçdışı” görüşünü eleştirmeden ele alırken "Din ve Tanrı Arketipi”, “psikoterapik din ve Tanrı”, “zıtlık” ve "kişilik tipolojileri” görüşlerini eleştirel olarak kitlesine yönlendirmiştir. İBDA'nın diğer bir yayın organı olan “Aylık” dergisi de Jung’un "rüya” görüşlerini eleştirmiş ancak diğer konuları eleştirmeden vermiştir (bkz. Tablo-3). Kur'ani Hayat dergisi de "arketip" ve “zıtlık/kompleks” konusunda Jung'u eleştirirken yazısında ele aldığı diğer görüşlerini olumlu şekilde anlatır (bkz. Tablo-3).

Tablo-3'a bakıldığında Jung'un konuları üzerinde iki hususta İslami dergilerin ittifak sağladığı düşünülebilir. Bunlardan birincisi "İslami dergilerin hepsi yazılarında Jung'un "persona”, “anima-animus" ve "self”" kavramlarına yer vermemişlerdir". İkincisi ise araştırmada incelenen bütün İslami dergiler "kolektif bilinçdışı” kavramı üzerinde olumlu bir dünya görüşüne sahipler. Jung'u yeri geldiğinde eleştiriye tabi tutan İBDA dergileri bile "kolektif bilinçdışı" konusunda Jung’u takdir ederler (bkz. Akademya, 1998; Aylık, 2016; 2009). "Kolektif bilinçdışı” kavramı (dergilerin anlatımına göre "kolektif şuuraltı" ya da "şuuraltı") tüm dergilere göre İslami anlayışla uyumludur. Akademya dergisindeki Oymak tarafından kaleme alının yazıda bu durum açıça yazmaktadır: Jung, “kolektif şuurdışı” kavramını İslam'ın ve özelde de İBDA anlayışının bir kavramı olarak Batı'da ilk olarak dile getiren kişidir (Oymak, 1998).

Tablo-3'e göre, İslami dergiler, Jung'un görüşlerini bütüncül olarak değil, yayın amaçlarına, toplumsal ortama ve zamana göre yani ihtiyaca binaen kullandıklarını anlamaktayız. Kur'ani Hayat dergisinde İslamoğlu bu durumu bir Arap atasözü ile veciz bir şekilde anlatmıştır: "Huz ma safa; da' ma keder!' yani “sana faydalı olanı al zararlı olanı bırak”. İslamoğlu, Jung'un işimize gelen tarafını almalıyız işimize gelemeyeni almamalıyız demektedir. İşte bu anlayış İslami dergilerin Jung ve onun görüşleri hakkındaki yayın politikasını göstermektedir. Devrimci ve 1slahatçı özelliklere sahip İslami dergilerin Jung’un kavramlarını bütüncül ve sistemli bir şekilde ele almamalarının nedeni bu anlayışa dayanmaktadır diyebiliriz. Araştırmada incelenen dergiler arasında, Jung’tan en fazla bahseden Müslüman Sesi dergisi bile Jung’un her görüşünü alıp kullanmak yerine yayın amaçlarına, toplumsal ortama ve zamana göre kendilerince yeterli miktarda belli başlı görüşlerini almışlar ve kitlelerine yönlendirmişlerdir.

İslami dergilerin Jung'u kullanma amaçları da birbirinden farklıdır. Araştırmanın alt problemlerinden ikincisi bunu tespit için oluşturulmuştur. Yukarıda İslami dergilerin Jung ve onun görüşlerini iki amaç doğrultusunda ele aldıkları görülmüştür. Bunlardan biri 'Jung'un otoritesine 
işaret ederek derginin kendi iddialarını kuvvetlendirmek" iken diğeri ise Batılı emsallerine göre farklı kabul edilen Jung'u belli konularda eleştirip "hedef kitlesine yönlendirerek Jung'u kullanmak" şeklindedir.

Mesela, araştırmada 1slahatçı dergilerden olan Sebilürreşad ve Müslüman Sesi dergileri, çeşitli bilgi ve öncüllerle temellendirdikleri iddialarını Jung'un hem şahsi hem de bilimsel otoritesine işaret ederek kuvvetlendirmişlerdir. Bu şekilde hedef kitlelerini yönlendirmeyi amaçlamışlardır. Jung'u iddialarını kuvvetlendirmek için kullanan bu dergiler Jung'un görüşlerini eleştirmemişler tam tersine Jung'un şahsına ve bilimsel otoritesine saygınlık ve üstünlük atfetmişlerdir. Jung'un şahsına ve bilimsel otoritesine atfedilen saygınlık ve üstünlük ifadeleri şunlardır: "Jung'un çok değerli sayılan bir kitabından alıntı" (Sebilürreşad), "psikolojinin bayraktarı, Zürihli Yung, ekolmezhep sahibi, Zürihli profesör, Zürihli büyük psikolog, Zürihli büyük ruhiyatçı doktor, Zürihli ruhiyatçı” (Müslüman Sesi), "Psikanalizin bir diğer babası” (Kültür Dünyası), “din karşıtı olmayan Batılı bir psikolog, çağın büyük psikanalizlerinden” (Genç dergisi).

İslami dergilerden bazıları, Jung'u veya onun görüşlerini kullanırken, Jung hakkında çeşitli durumlara ve eleştirilere dikkat çektikten sonra hedef kitlesindeki Jung algısını yönlendirerek kullanmışlardır. Tevhid, Akademya, Yörünge, Yeni Zemin, Aylık ve Kur'ani Hayat dergileri Jung'u ve onun görüşlerini bu şekilde kullanmışlardır. Bu dergilerin hepsi ağır veya hafif bir şekilde Jung'u veya onun görüşlerini eleştiriye tabi tutarlar ve kitlesini dikkat etmeye sevk eder. Her biri eleştirse de "Jung'un emsallerinden farklı" olduğunu kabul ederler. Ayrıca Jung'u anlamaya çalışırken kendi eleştirilerini dikkate alıp akılda tutarak okunmasını tavsiye ederler. Jung'u ve onun görüşlerini eleştiren dergiler bile Jung'a, Freud ve benzerleri gibi tamamen olumsuz bakmamışlardır. Aksine, Jung hakkında çeşitli durumları ve eleştirileri dikkate alarak Jung'un okunmasını istemişler ve böylece hedef kitlelerindeki Jung algısını yönlendirmeye çalışmışlardır. Bu durum aynı anda bizi şu sonuca da ulaştırır: "İslami dergiler Jung'u eleştirseler de emsallerinden farklı olduğunu kabul ettikleri için Jung İslami kesim tarafindan kabul edilmiş bir olguya sahiptir”. Buna kısaca "Jung Olgusu” diyebiliriz. "Jung Olgusu” İslami dergiler açısından olumsuz bir algıya sahip değildir. Eleştirilecek yönleri olsa da Jung, İslami dergilerin kabul ettiği bazı "hakikatleri" Batı'da dile getiren bir "otoritedir". Bu hakikatlerden biri de "kolektif bilinçdışıdır". Bütün İslami dergiler için üzerinde ittifak edilen hakikatlerden biridir "kolektif bilinçdışı". Din ve Allah inancının insanın ruhunun derinliklerine işlenmiş bir kod olarak 


\section{Bazı İslami Dergiler Örnekleminde Carl Gustav Jung: Nitel Bir Araştırma}

"Kalû Beladan" bu yana var olduğu (Mevdudi, 1991) İslami anlayışını Jung’un "kolektif bilinçdışı" kavramı ile özdeşleştiren İslami dergiler için Jung emsallerine göre çok önemli ve değerlidir. Dahası Jung'un "kolektif bilinçdışı” kavramını evrim teorisi ile paylaşamayacak kadar sahiplenicidirler (bkz. Aylık Dergisi, 2009). Bunun için araştırmadaki tüm İslami dergiler Jung üzerinde olumlu bir algiya sahiptirler.

İslami dergilerin Jung'un “otorite” görmesi yorumu hakkında daha farklı şeyler de söylenebilir. Her şeyden önce İslami dergiler Jung'un "otorite” olmasına farklı yaklaşmaktadırlar. Söz konusu bu "otorite" bazı İslami dergiler için temellendirilen kendi iddialarının "kuvvetlendiricisi" iken bazı İslami dergiler için dünya görüşlerine uygun yönlerinin alınması gereken bir "modeldir". Ancak araştırmada Jung'un otorite olmadığını iddia eden bir İslami dergi yoktur. Bunu nereden anlıyoruz? Araştırmanın üçüncü alt problemine ilişkin bulgu bu yoruma ulaştırmaktadır. Buna göre araştırmadaki tüm İslami dergilerin Jung'un bizzat şahsına, kariyerine veya bazı görüşlerine yönelik övücü yargıları, takdirleri bulunmaktadır. Jung'un bazı görüşlerini eleştiren “Akademya, Aylık ve Kur'ani Hayat" gibi dergiler bile Jung'un emsallerinden farklı olduğunu kabul etmişler ve yeri gelmiş övgüler dizmişlerdir. Mesela, “... ruhiyatın .... Üç kurucusundan biri addedilen ...”; “... çağının ruha inanmaz ruhiyatçıları içinde, onlardan ayrı bir anlayışı temsil eder." (Akademya); “... laboratuvarda deney yapan fizikçi titizliğinde sistemli kayttlar yapan ...” (Ayllk); Jung'un metaryalist ve pozitivist Bati psikolojisine alternatif diyebileceğimiz yaklaşımı..." (Kur'ani Hayat). Öte yandan Jung'u bilimsel olarak hiç eleştirmeyen "Müslüman Sesi” gibi dergiler ise yazılarında temellendirdikleri iddialarını kuvvetlendirirken Jung'u kolaylıkla kullanmışlardır. Böylece bu dergiler, İslami kesimdeki "Jung Olgusuna" mutlak, salt ve kuvvetli anlamda olumlu bir algı yönlendirmiştir. Yeri geldiğinde eleștiren ama Jung'un “otorite” olmasını kabul eden İslami dergiler ise dikkat çekilecek noktaları hedef kitlesine yönlendirerek Jung'u kullanmışlardır. Bu yüzden bu dergiler ise İslami kesimdeki "Jung Olgusuna" eleştirel, faydacı ve döngüsel akılcı anlamda olumlu bir algı yönlendirmiştir. Eleştirel ile olumlu algının birbirine ters olduğu düşünülse de burada kastedilen Jung İslami dergiler için asla bir Freud gibi görülmemesidir. Akademya dergisi başta olmak üzere İslami dergilere göre Jung Freud ya da emsalleri gibi değildir. Bu da Jung olgusuna olumlu algı katmaktadır (bkz. Şekil -2). 


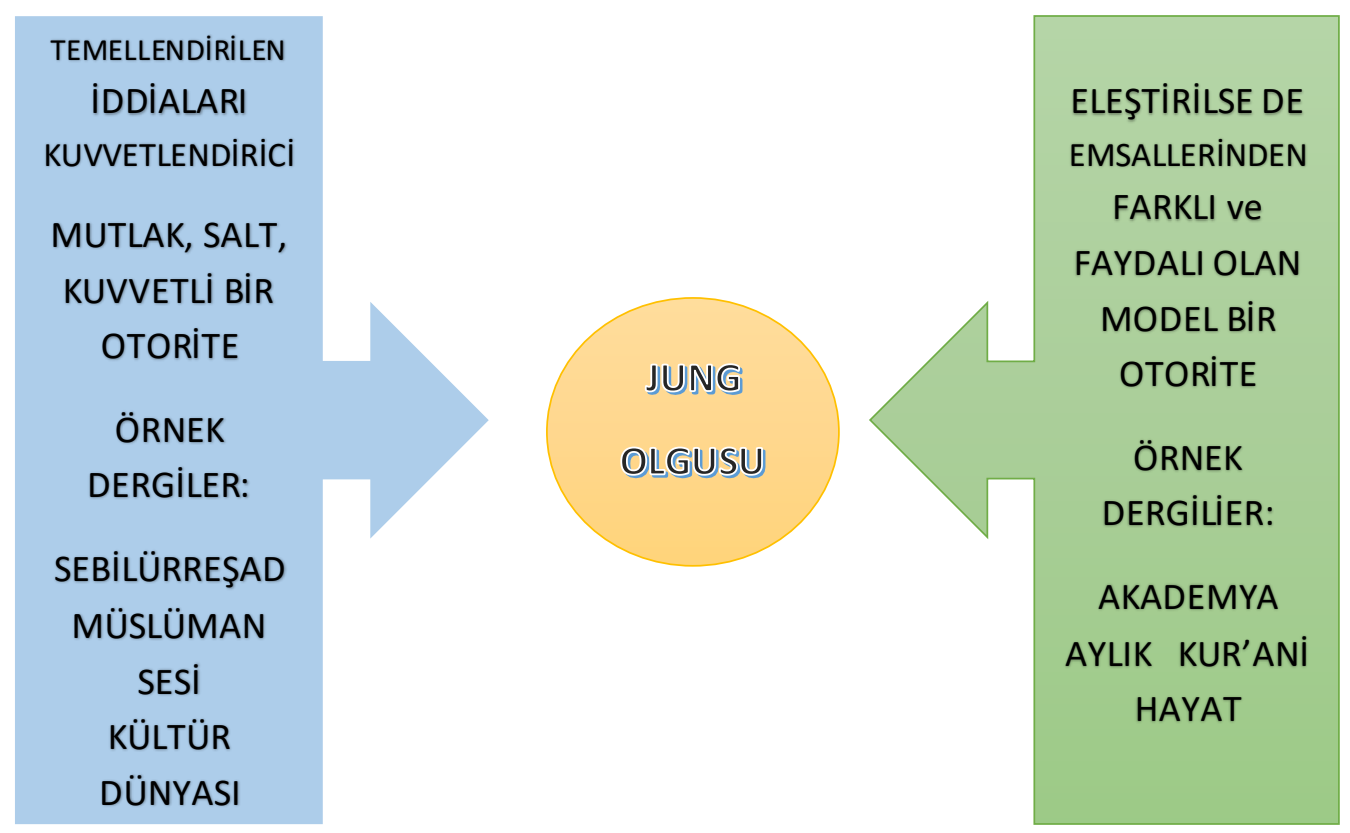

Şekil-2 İslami Dergilerin “JUNG OLGUSUNA” Yönlendirdikleri Olumlu Algılar.

İslami dergilerin Jung'u ve onun görüşlerini ele alırken hedef kitlesine yönlendirdikleri bilimsel ve mantıksal üsluplarının "safsata" açısından da değerlendirilmesi gerekebilir. En başta şunun altını çizmekte fayda vardır: "Safsata hatalı ya da yanlış akıl yürütmeyle bir çıkarsama yapmaktır ve çoğu zaman safsatalar “sosyal bir olgudur” (Uyar, 2019). Uyar’a göre (2019) hatalı düşünmek, yanlış bilmek safsata yapmak anlamına gelmez. Genelde safsatalar başkalarına düşünce aktarırken, tartışırken, münazara ederken, birini suçlarken ya da bir kişiyi, fikri savunurken ortaya çıkar (Uyar, 2019). Safsata ile mugalatanın arasındaki fark ise safsata her zaman yanıltmak demek değildir (Emiroğlu, 2008: 483-483). Bunun için safsata bir dünya görüşünün aktarılma biçiminin yanlışlı̆̆ da olabilir. İslami dergilerin Jung'u ve onun görüşlerini kullanma üsluplarını bu açıdan değerlendirebiliriz.

Araştırmada incelenen İslami dergiler yazılarında hedef kitlesini yönlendirmek için Jung olgusuna kattıkları olumlu algının üslubu "bir bilen yani otorite safsatasına" kısmen benzemektedir. Dikkat edilirse "kısmen benzemektedir" ifadesi kullanılmıştır. Çünkü John Locke’a göre "bir bilen (otorite) safsatası" her zaman safsata olmayabilir. Bir fikri kabul ettirmek için otoritenin 


\section{Bazı İslami Dergiler Örnekleminde Carl Gustav Jung: Nitel Bir Araştırma}

saygınlığının kötüye kullanılmasında "bir bilen (otorite) safsatası” ortaya çıkar (Uyar, 2019). İslami dergilerin safsata yaptığını iddia edemeyiz ama benzemekte olduğunu iddia etmekteyiz. Çünkü Jung’un otoritesinin saygınlığını kötüye kullanmamışlardır. Yani “Jung dediyse kesinlikle doğrudur” anlayışı yoktur. Jung'u eleştirmeksizin görüşlerini kullanan İslami dergiler bile “Jung dediyse kesinlikle doğrudur' yaklaşımında değildirler. Müslüman Sesi gibi dergiler Jung’u kullanmadan önce kendi dini, dünyevi iddialarını temellendirdikten sonra Jung’un görüşlerini kuvvetlendirici olarak kullanmışlardır.

Safsata yerine, İslami dergilerin bilimsel üslupları “döngüsel akıl yürütme” ve kültürel “etnosentrik bakış” açısı olarak görmek daha doğru olabilir. Etosantrik bakış açısı ile "döngüsel akıl yürütme" (circular reasoning) birbirine benzemektedir. "Döngüsel akıl yürütme" sonucun, geçerliliği zaten sonuca bağlı olan bir varsayıma dayandırılmasıyla tanımlanan bir akıl yürütmedir (Budak, 2009: 217). Bu yüzden "Batı" ve "biz Müslümanlar” ayrımı İslami dergilerde çok keskindir. Jung'un doğrularını saptarken kendi dini argümanları temel almaktadırlar. Ayrıca köktendincilik ile ideoloji veya etnosentrizm arasında kuvvetli ilişki var olması (Türker ve Payas 2021: 339) mümkündür ki İslami dergilerde de belirli dini veya ideolojik dogmalara aykırı olan görüş ya da kişiler anında reddedilmektedir. Örneğin Freud ve cinsellik görüşü gibi. Ancak Jung’un bazı düşünceleri İslam'a ters olmadığı için İslami dergiler Jung'u Freud'dan ayrı tutmaktadırlar. Jung’un "kolektif bilinçdışı” kavramına İslami dergilerin olumlu yaklaşması “döngüsel akıl yürütme” çabasının bir sonucudur. İslami anlayışa doğru olduğu için "kolektif bilinçdışı" kavramı İslami dergiler tarafından eleştirilmeden kabul edilmiştir. Bu Gazali’nin İslam filozoflarını eleştirirken kullandığı mantığa benzemektedir. Çünkü Gazali’nin İslam filozoflarını eleştirdiğinde “döngüsel akıl yürütme” yaptığı söylenir (Yıldız, 2011: 73 vd.; Erdoğan, 2014: 87 vd.). Örneğin, “Allah vardır çünkü Kuran Allah'ın var olduğunu söylüyor. Kuran doğrudur çünkü Allah'ın kitabıdır."

İslami dergilerin Jung'u ve onun görüşlerine genel yaklaşımlarını, bugün Türkiye'de kabul ettirilmeye çalışılan İslami psikoloji anlayışı üzerinden de değerlendirme yapmak mümkündür. Bilimsel bilginin İslamileştirilmesi (Altun, 2014: 163 vd.) gibi psikolojiyi de İslamî perspektiften görmek gerektiğini iddia eden İslami psikoloji Batı psikolojisinin pozitif yönlerini İslami perspektifle birleştirerek insanı bütünsel olarak yaklaşma tezinden hareket ettiğini iddia etmektedir (Uysal, 2021). Batı psikolojisinin negatif ve pozitif yönleri nasıldır? Batı psikolojisinin negatif 
yönleri ne olacak? Ya da Batı psikolojisinin kime göre pozitif ve negatif yönleri nedir? Bu sorular uzadıkça uzar. Ancak İslami psikoloji diyerek din psikolojisi alanına günümüz modern bilimin paradigmalarına uygun olmayan bir anlayış yerleştirilmeye çalışıldığı anlaşılmaktadır. İslamoğlu gibi İslami yazarların iddia ettikleri "işe yarayan alınacak, işe yaramayan atılacaksa" İslami dergiler böyle bir İslami psikolojiyi, 2018'deki Uluslararası İslami Psikoloji konferansından ${ }^{6}$ çok önceleri yapmışlardır. İslami psikoloji öncülerinden M. Bedri 1975'teki konferansında “Kertenkele Deliğindeki Müslüman Psikologlar?" adlı konuşmasında Müslüman psikologlardaki şuursuzca Batı kopyacılığını eleştirmiş̧ir (Uysal 2018). Bedri'nin izinden gitmeyi amaçlayan din psikologlarından bazıları da Türkiye'ye İslami psikoloji fikrini yeni bir şey olarak sundukları imajını vermektedirler (bkz. Balıkçı, 2021). Türkiye'de akademik ve modern anlamda din psikolojisi Egemen (1951) ile başladığı kabul edilirken (Koç, 2015), psikolojinin İslamlaştırılması demek olan "dini veya İslami psikoloji” mantığı Türkiye'de Osmanlı'dan bu yana hep var ola gelmiştir (Köse, 2008). Ayten'e göre Arap dünyasında din psikolojisi diye bilimsel bir kürsünün olmadığı görülmekteyken (Ayten, 2012: 88) İslami psikoloji ya da psikolojinin ve bilimin İslamileştirilmesini savunmak paradogsal bir durumu çağrıştırmaktadır (Seyhan, 2021).

Son olarak, Araştırmada incelenen İslami dergilerin 1940'lardan bu yana Jung'u ve onun görüşlerini hedef kitlelerine yöneltmelerinin hiç faydası yok mudur? Bu soruya şu şekilde bir yorum getirilebilir: İslami dergilerin Jung hakkındaki yazıları bilimsel olmasa da "din psikolojisinin İslami kesim tarafından dışlanmamasını, olumsuz bir algıya kurban gitmemesini sağlamaktadır" denilebilir. Yani İslam tarihi içinde felsefenin başına gelenler din psikolojisinin başına gelmeyebilir. Hatırlanacağı üzere, İslam tarihindeki din-felsefe karşıtllı̆ı sonucu felsefenin medreselerden okutulmasına müsaade edilmediği bilinmektedir. Müslüman kesimin bugün bile felsefeye karşı ön yargısının olmasında, felsefecilerin geçmişte -başta Gazali olmak üzerekelamcılar tarafından tekfir edilmesini gösterebiliriz. "Tekfiı” kavramının dini bir kavramdan çok sosyal algı kavramı olduğu (Seyhan, 2012) göz önüne alınırsa felsefenin bilimsel kaygılar yerine dini ve sosyal kaygılarla İslam coğrafyasında bütüncül olarak dışlandığı anlaşılır (Aydın, 2012). Osmanlı medreselerinde felsefenin okutulmasının kaldırılmasında da benzer nedenler görülür

\footnotetext{
${ }^{6}$ Bkz. https://twitter.com/zaimuniv/status/1056464643890298880

${ }^{7}$ Bedri'nin bu dediği söz çok sübjektiftir ve kültürel etnosentik bir ifadedir. Başka biri de çıkıp i̇slami psikolojinin merkezleri olan Malezya, Mııır, İran gibi ülkeleri kastederek “Ortadoğu'nun kertenkele deliğinden çıkan Türk din psikologları" diyebilir.
} 


\section{Bazı İslami Dergiler Örnekleminde Carl Gustav Jung: Nitel Bir Araştırma}

(bkz. Yakupoğlu, 1996). İslami dergilerin Jung hakkında verdikleri sübjektif bilgiler ve Jung hakkında kitlelerini genellikle bizden biri gibi yönlendirmeleri Müslüman kesimin din psikolojisi hakkında olumsuz bir yargı içinde olmalarını engelleyebilir. İslam coğrafyasında felsefenin başına gelenler, din psikolojisine gelmeyebilir diyebiliriz.

\section{Sonuç ve Öneriler}

Psikolojinin bağımsız bir bilim olarak ortaya çıktığı dönemin akabinde psikoloji bilimi -eski adı ile ruhiyat- Anadolu coğrafyasında da incelenmeye başladı. O dönemde eğitim için Avrupa'ya giden Türkler Freud, Jung, Wundt gibi psikologlardan haberdar olmuştular. Özellikle Jung'un görüşleri ve bazı kitapları harf inkılabıyla, erken dönemde tercüme edilmeye başlandı. İşte bu araştırmada Jung'un erken dönemlerden günümüze kadar gelen İslami dergilerdeki görüşleri incelenmiştir.

Araştırmanın giriş kısmında genel hatları ile Jung'un psikolojiye ve özelde din psikolojisine sunduğu orijinal görüşleri anlatılmaya çalışılmıştır. $\mathrm{Bu}$ görüşlerini içeren "Şekil-1" oluşturulmuştur. Bu “Şekil-1”de anlatılanlar Freud'un buzul dağı ile benzer olarak Jung'un ada veya adacıkları anlatan temsiline benzetilmeye çalışılmıştır. Jung’un psikolojiye sunduğu en önemli kavramlar "kolektif bilinçdışı", “arketipler”, "din ve Tanrı arketipi”, “dinin psikoterapik etkisi”, “gölge”, “persona” ve "self” olarak verilebilir.

Araştırmanın yöntem kısmında nitel yöntem içinde yer alan doküman analizi yapılacağı söylenmiş ve çalışma grubu belirlenmiştir. Buna göre Jung’tan bahseden İslami ve aktüel dergilerden bazıları araştırmaya dahil edilmiştir. Bu dergiler kronolojik sırası ile şöyledir: "Sebilürreşad”, "Müslüman Sesi”. “Tevhid”, “Yeni Zemin”, “Yörünge”, “Akademya”, “Kültür Dünyası”, “Aylık”, “Genç”, "Kur 'ani Hayat”. Bu dergilerin araştırma seçilme şekli ve ölçütü ise "İslami Dergiler Projesi" adlı internet sitesinde yer alan dergilerde Jung'tan bahseden yazılarının olmasıdır. Bunun araştırmanın örneklemi "amaçlı örnekleme” ile buna bağlı olarak "ölçüt örnekleme” yöntemi tercih edilmiştir. Araştırma deseni “durum çalışmasıdır”. Bu dergilerin incelenmesini için "Araştırmada incelenen İslami ve aktüel dergilerin Jung'a ve onun görüşlerine yaklaşım tarzları nasıldır? ” ana problemi ve buna bağlı olarak üç alt problem belirlenmiş ve araştırma sadece bu problemlerin 
araştırılması ile sınırlandırılmıştır. Bu alt problemlerden sonra dergilerin ve Jung ile ilgili yazıların ayrıntılı bilgileri verilmiştir. Araştırmada analizi yapılacak olan dergilerin ve yazıların genel bilgilerini gösteren bir tablo da oluşturulmuştur (bkz. Tablo-1).

Araştırmanın bulgular kısmında kronolojik sıra ile tüm dergilerin yazılarında Jung ve onun görüşlerinin yer aldığı metinler tespit edilmiş ve metin içi bilgiler ayrıntılı bir şekilde verilmiştir. Daha sonra İslami dergilerin bu metin içi bilgileri ile Tablo-1 göz önüne alınarak dergilerin genel ve alt özelliklerine göre sınıflandırıldığı Tablo-2 oluşturulmuştur. Araştırmanın birinci alt problemini cevaplamak için İslami dergilerde Jung'un kavramlarından hangilerinin anlatıldığ tespit edilmiş ve bununla ilgili Tablo-3 verilmiştir. Buna göre Jung'un görüşlerinden olumlu olarak bahseden dergilerin karşısına "+", hem eleştirel hem de kısmen olumlu yaklaşan ifadelerine ise "+/-" işareti konulmuştur. Araştırmanın ikinci alt problemi olan "Araşstırmada incelenen İslami dergiler hangi amaçlar için Jung'u ve onun görüşlerini kullanmışlardır?” sorusuna cevap aranmıştır. Elde edilen birinci kısım bulgulara göre İslami dergilerin bir kısmı, Jung'un otoritesine işaret ederek temellendirdikleri iddialarını kuvvetlendirmek için Jung'tan ve onun görüşlerinden bahsetmişlerdir. Bu dergiler, "Sebilürreşad", "Müslüman Sesi”, "Kültür Dünyası", "Genç" dergileridir. İkinci kısım bulgulara göre ise İslami dergilerin bir kısmı eleştiriye, mesaja vb. bir şeye "dikkat çekip hedef kitlesini yönlendirerek Jung'u kullanmak" olup bu tür dergiler ise “Tevhid”, "Yörünge”, Akademya”, “Aylık” ve "Kur'ani Hayat’tır”. Üçüncü alt probleme ilişkin olarak da bulgular tespit edilmiş ve bu tespitler de "Jung'un bizzat şahsına, kariyerine ve bazı görüşlerine yönelik övücü yargılar" ve "Jung'un bizzat şahsına, kariyerine ve bazı görüşlerine yönelik eleştirel yargılar” olarak ikiye ayrılmıştır.

$\mathrm{Bu}$ alt problemlerin bulgularından sonra ana probleme ilişkin bulgular ve yorumlar ise "İslami Dergilerin Jung'a ve Onun Görüşlerine Genel Yaklaşım Tarzları" başlığı altında verilmiştir. Buna göre;

$\mathrm{Bu}$ dergilerin hiçbiri, şekil ve format açısından bilimsel dergiler olmadığı açıktır. Yazıların hiçbiri günümüz bilimsel metotlarına ve formatlarına uygun değildir. Bazılarında intihal olduğu görülmektedir (bkz. Müslüman Sesi-Durukan ve Yeni Zemin-Yörünge dergileri). Araştırmadaki tüm İslami dergilerin Jung hakkında ortak düşündükleri yönler vardır. Bunun için "tüm İslami dergilerin yayın hedeflerinin ortak konusu/kümesi “Jung'tur” diyebiliriz. Çünkü İslami dergilerin ve hedef kitlelerinin Jung üzerinde ortak bir "Jung Olgusu” vardır. Amaçları bilimsellikten ziyade 


\section{Bazı İslami Dergiler Örnekleminde Carl Gustav Jung: Nitel Bir Araştırma}

dünya görüşleri veya ideolojileri doğrultusunda hedef kitlelerinde bulunan Jung olgusunu ortaya attıkları iddialarla veya algılarla yönlendirmektir. Bu dergilerin yayın anlayışları yönlendirmek olup (kara) propaganda yapmak değildir.

İslami dergilerin yayın hedeflerinin ortak konusu "Jung" ise de onu ele alış tarzları farklıdır. Dahası Jung'un psikolojiye katkı sunduğu görüşlerini konu edinmeleri bile farklıdır. Tablo-3'te Jung’un tüm görüşlerinin bütüncül olarak anlatıldığı bir yazı yoktur. Her dergi yayın hedefi doğrultusunda yeteri miktarda Jung'un çeşitli kavramlarını almıştır. Kur’ani Hayat dergisinde İslamoğlu bunu veciz bir şekilde özetlemiştir: "Sana faydalı olanı al zararlı olanı bırak”. Bunun için araştırmada Jung’un "self”, "persona”, “anima-animus” arketipleri hiç ele alınmamıştır. Öte yandan “din ve Tanrı arketipi” ile "psikoterapik din ve Tanrı görüşü” en fazla işlenen konulardandır. İslami dergilerin bazıları, Jung’un kimi kavramlarını eleştirirlerken kimi kavramlarını da takdirle anarlar. Eleştirmedikleri kavram olan "Kolektif bilinçdışı" kavramı ise araştırmadaki tüm dergilere göre İslami anlayışla uyumludur.

Araştırmada İslami dergilerin Jung'u kullanma amaçları da birbirinden farklı olduğu görülmüştür. İslami dergiler Jung'u kullanma amaçları iki şekildedir: a. “Jung’un otoritesine işaret ederek derginin kendi iddialarını kuvvetlendirmek", b. Eleştirse de Batılı emsallerine göre İslami anlayışa daha yakın kabul ettiği için Jung'un “belli bir yöne dikkat çekip hedef kitlesini yönlendirmek için Jung'u kullanmak". Yani bir durumda mutlak ve kuvvetli bir otorite iken diğer durumda emsalleri arasında özel yere sahip olduğu için eleştirel ama faydalı bir otoritedir. Sonuçta araştırmadaki tüm dergiler için Jung öyle ya da böyle bir otoritedir. Sonuç olarak, her şeyden önce İslami dergiler Jung'un "otorite” olmasına farklı yaklaşmaktadırlar. Söz konusu bu "otorite" bazı İslami dergiler için temellendirilen kendi iddialarının "kuvvetlendiricisi" iken bazı İslami dergiler için dünya görüşlerine uygun yönlerinin alınması gereken faydalı bir "modeldir”. Bu yüzden araştırmada Jung’un otorite olmadığını iddia eden bir İslami dergi yoktur.

Araştırmada incelenen İslami dergiler yazıları ile hedef kitlesini yönlendirmek için Jung olgusuna kattıkları olumlu algının üslubu "bir bilen yani otorite safsatasına" kısmen benzemektedir. Araştırmanın yorum kısmında İslami dergilerin Jung'un otoritesini kötüye kullandıklarını iddia edilemeyeceğinden kısmen safsataya benzemekte sonucuna ulaşılmıştır. Çünkü İslami dergilerin bilimsel üslupları "döngüsel akıl yürütme” ve kültürel "etnosentrik" bakış açısıdır. "Batı" ve "biz Müslümanlar" ayrımı İslami dergilerde çok keskindir. Ayrıca kurguladıkları bilimsel mantık 
“döngüsel akılcılıktır”. Psikolojinin İslamileştirilmesini savunan ve Batı psikolojisinin pozitif yönlerini alıp diğer yönlerini bırakmayı amaçlayan bazı İslami psikologlar (Uysal, 2021) ile İslami dergilerin mantıklarının aynı olduğu kanaatine ulaşıııışır. İslami dergilerin Jung hakkındaki yazıları bilimsel olmamakla beraber, "din psikolojisinin İslami kesim tarafından dışlanmamasını, olumsuz bir algıya kurban gitmemesini sağlamaktadır" denilebilir yorumuna ulaşılmıştır. $\mathrm{Bu}$ yüzden İslam tarihi içinde felsefenin başına gelenler din psikolojisinin başına gelmeyebilir denilebilir.

Araştırmanın geneli ve sonuçları dikkate alındığında bazı önerilerde bulunmak mümkündür: İslami dergiler üzerine yapılan bu doküman analizi daha farklı analiz teknikleri ile genişletilebilir. Ayrıca "Jung" üzerine yapılan bu araştırma daha farklı psikologlar üzerine de yapılabilir. Mesela, Freud'un İslami kesim tarafindan ele alınış tarzları analiz edilebilir. İslami dergilerdeki yazarlar üzerinde din psikolojisinin çeşitli konuları üzerinde mülakat ya da anket çalışmaları da yapılabilir. 1930-1940'lı yıllardan bu yana Türk din psikolojisinde ele alınan başka kavramlar ya da olgular üzerine de doküman analizleri yapılabilir. Örneğin Jung'un "kolektif bilinçdışı” eleştiren Ülken'in Jung veya diğer psikologları ele alış tarzı ile İslami dergilerin bakış tarzları karşılaştırılabilir. "Jung" üzerine yapılan bu araştırma bağlamında İslami dergilerin bilimsel ve modern bir din psikolojisi yapamadıkları göz önüne alıp İslami psikoloji yapma amacında olanlar için modern bilim dışı yöntemlerle farklı hayallere kapılmamalarına katkı sunabilir. İslami psikolojinin eleştirilmesine bu çalışma katkı sağlayacağından dolayı İslami dergiler üzerinde daha farklı çalışmalar da yapılabilir.

\section{Kaynakça}

Altun, V. K. (2014). “İslami Düşüncenin Yeniden İnşa Çabası: Bilginin İslamileştirilmesi”, Birey ve Toplum, c: 4, s: 8, ss:163-191.

Armağan, M. (1997). "Rüya, Bilinçaltı ve Şehir”. Kültür Dergisi. Ekim, sayı 6, ss: 25.

Aydın, S. (2012). “Gazali’nin Filozofları Eleştirindeki Nihai Hedefi Üzerine”. Süleyman Demirel Üniversitesi İlahiyat Fakültesi Dergisi, c: 1; s:28; ss: 15-38.

Ayten, A. (2010). Psikoloji ve Din, Psikologların Din ve Tanrı Görüşleri. İstanbul: İz Yayınc1lik. 
Ayten, A. (2012). “Arap Ülkelerinde İslami Psikoloji ve Din Psikoloji Çalışmaları”. Adana: Çukurova İlahiyat Fakültesi Dergisi, c: 12, s: 5, ss: 51-100.

Balaban, M. R. (1953). “Dinî Hayatın Amaçları-2”. Müslüman Sesi, c:5; s:79; 18 Temmuz 1953. İzmir.

Balaban, M. R. (1949a). “İnsan İki Taraflı Aynadır”. Müslüman Sesi, c:1; s:4; 26 Ocak 1949. İzmir.

Balaban, M. R. (1949b). “İnsanın Aslı ve Görevi Hakkında (Yung) ile İslam Tasavvufu Arasındaki Görüş Birliği”. Müslüman Sesi, c:2 s:20; 7 Aralık 1949. İzmir.

Balaban, M. R. (1949c). “İnsanın Aslı ve Görevi Hakkında (Yung) ile İslam Tasavvufu Arasındaki Görüş Birliği”. Müslüman Sesi, c:2 s:21; 7 Aralık 1949. İzmir.

Balaban, M. R. (1950). “Tanrı Kitabından Sapıklara Uymayalım”. Müslüman Sesi, c:2, s:32; 12 Ağustos 1950. İzmir.

Balaban, M. R. (1951). “Tanrı Kitabından: Din ve İman”. Müslüman Sesi, c:3; s:37; 22 Ocak 1951. İzmir.

Balaban, M. R. (1952a). “Din ve Terbiye”. Müslüman Sesi, c:4; s: 58; 11 Nisan 1952. İzmir.

Balaban, M. R. (1952b). “Din ve Terbiye 2". Müslüman Sesi, c:4; s: 59; 3 May1s 1952: İzmir.

Balaban, M. R. (1952c). “İlim ve Din Ahengi 3”. Müslüman Sesi, c:4; s: 62; 17 Haziran 1952. İzmir.

Balaban, M. R. (1952d). “İman ve Hayat”. Müslüman Sesi, c:4; s: 68; 4 Aral1k 1952. İzmir.

Balıkçı, Ü. (2021). "İslami Psikolojinin İmkânı, Gerekliliği ve Nasıllığı”, Eski Yeni, s: 44; ss: 409-431.

Duru, M. E. (2014). “Sayı Rüyalarının Anlamı Üzerine”. Aylık Dergisi. Temmuz 2014, sayı 119.

Egemen, B. Z. (1952). Din Psikolojisi: Saha, Kaynak ve Metot Üzerine Bir Deneme. Ankara: Ankara İlahiyat Fakültesi Yayınları.

Emiroğlu, İ. (2008). "Safsata". DİA Maddesi. Ankara: Diyanet Vakfı Yayınları.

Erdoğan, Ö. F. (2014). “Gazali Üç Meselesinde İbn-i Sina’ya Karşı Ne Kadar Tutarlı?” Diyanet İlmi Dergi, c: 50, s:1, ss: 87-110.

Ertan, V. (1992). "Balaban, Mustafa Rahmi”, DİA Maddesi, TDV İslam Ansiklopedisi, c:5 s:12.

Franz, M. L. Von. (2008). "Bilinçdışı ve Bilimler” (Çeviri:Ali Nahit Babaoğlu). Aylık Dergisi. Şubat, say1 41 ss: 58. 
Gebel, S. (2003). Psikoloji-Din İlişkisi ve Jung. M.Ü. Sosyal Bilimler Enstitüsü (Yayınlanmamış Yüksek Lisans Tezi). İstanbul.

Glover, E. (1991). Freud or Jung. USA: Northwestern University Press.

Güleç, Z. N. (2016). “Şiirde Rüya; Rüyada Tabir II”. Aylık Dergisi. Aralık 2016, say1 147.

Gürses, İ. (2007). “Jung'cu Arketip Teorisi Bağlamında Tasavvufi Öykülerin Değerlendirilmesi: Sîmurg Örneği ’”. Bursa U. İlahiyat Fakültesi Dergisi, c.:16, s: 1, ss:77-96.

İslamoğlu, M. (2009). “Şahsiyet Eğitimi Modeline Giriş’te Kişilik Tipolojilerinin Yeri -Jung Örneği-" Kur'an-i Hayat. Mart-Nisan 2009 say1 5 ss: 20-25.

Jung, C. G. (1933). Modern Man In Search of A Soul. London: K. Phuel, Trench, Trubner.

Jung, C. G. (1961). Erinnerungen, Träume, Gedanken. Almanca Aslından Çeviren: İris Kantemir. Anılar, Düşler, Düşünceler.İstanbul: Can Sanat Yayınları.

Jung, C. G. (1934). Ruhi Hayatta La Şuur. Çev.: M. Hayrullah. İstanbul: Vakit Gazete Matbaası.

Jung, C. G. (1949). Psychology of The Unconscius. New York: Dood, Mead And Company.

Jung, C.G. (1997). Analitik Psikoloji. Çev.: Erol Gürol. İstanbul: Payel Yayıncılık.

Kaplan, Y. (2015). “Batı'nın İslam Düşmanlığının Kısa Bir Arkeolojisi” Genç Dergisi. Şubat 2015, say1: 101 ss: 20-21.

Koç, M. (2015). “Türkiye’de Din Psikolojisi Çalışmaları”. Bursa: Uludağ Üniversitesi İlahiyat Fakültesi Dergisi, c: 1; s: 2; ss: 301-333.

Köse, A. (2008). Türkiye’de Psikoloji ve Din Psikolojisi. Yayınlanmamış Yüksek Lisans Tezi. Konta: Selçuk Üniversitesi Sosyal Bilimler Enstitüsü.

M. Mehtar F. (1957). “Din ve İlim” Sebilürreşad, c: 10, s: 247, ss: 169-172.

Mevdudi, Ebu'l Âlâ. (1991). Tefhimu'l-Kur'an, (I-VII). (Çev:M. H. Kayani vd.). İstanbul: İnsan Yayınları.

Moreno, A. (1974). Jungs, Gods and Modern Man. London: Sheldon Press.

Okumuş, E. (2019). “Sosyolojide Tanrı Tasavvuruna Bir Giriş Denemesi”. Eski Yeni, Eylül, ss: 201-222.

Oymak, E. (1998). “Carl Gustav Jung ve Din”. Akademya Dergisi. Ağustos 1998, say1 10, ss: 47 Özer, N. P. (2019). "Propagandada Yöntemler, Araçlar ve Bir Propaganda Modeli Olarak Herman ve Chomsky Propaganda Modeli”, Kritik İletişim Çalışmaları Dergisi, c: 1; s: 1; ss: 1530 .

Sambur, B. (2005). Bireyselleşme Yolu Jung’un Psikoloji Teorisi. Ankara: Elis Yayınları. 
Schultz, D. P. ve Schultz, S. E. (2007). Modern Psikoloji Tarihi. Çeviren: Yasemin Aslay. İstanbul: Kaknüs Yayınları.

Seyhan, B. Y. (2021). “Carl G. Jung’a Bakış Açısı: Türkiye’de Farklı Yaklaşımlar Üzerine Bir Durum Tespiti”. SADAB, 29-31 Ekim 2021 10. Uluslararası Sempozyum Bildirisi.

Seyhan, B.Y. (2012). “Gazali’nin İslam Filozoflarını Tekfir Etmesinin Yükleme Kuramları Açısından Değerlendirilmesi”. Çukurova İlahiyat Fakültesi Dergisi, c:12; s: 2; ss:277298.

Stevens, A. (1999). Jung. Çeviren: Ada Çayır. İstanbul: Kaknüs Yayınları.

Şenel, G. (2009). “Laplace'in Şeytanı Kuantum Fiziği ve İhtimal Dışı”. Aylık Dergisi. Şubat 2009 say1 53

Tengilimoğlu, D. ve Öztürk, Y. (2004), İşletmelerde Halkla İlişkiler. Ankara: Seçkin Yayıncılık. Tevhid Dergisi (1994). "Ruhi Hayatta Şuuraltı”. Yazarı Belli Değil. Mart, sayı 15 ss: 77.

Türker, N. ve Payas, D. (2021). "Kültürel Etnosentrizm ve Gastronomi: Türk Tüketicilerin Etnomofoji Tutumları Üzerine Kalitatif Bir Çalışma”, Gastroia: Journal Of Gastronomy and Travel, c: 5, s:2, ss: 336- 358

Ukray, M. (2017). Carl Gustav Jung-Jung Psikolojisi. Ankara: Yason Yayınları.

Uyar, T. (2019). Safsatalar. İstanbul: Destek Yayınları.

Uysal, S. (2018). Gelenek ve Gelecek Arasında İslami Psikoloji. İstanbul: Çamlıca Yayınları.

Ülken, H. Z. (1939). “Totemizm Etrafinda Münâkaşalar”, İnsan Mecmuası, c: 2, s: 12, ss: 9971002.

Yakupoğlu, K. (1996). Osmanlı Medrese Eğitimi ve Felsefesi, (Doktora Tezi). İstanbul: Marmara Üniversitesi SOSBE.

Yazıcılar, S. R. (2007). “Kendi İçimde Boğuluyorum”. Genç Dergisi. Ağustos 2007 sayı 11 ss: 37

Yeni Zemin Dergisi, (1994). Din ve Psikoloji. Çevirmen: Cengiz Şişman. Mart, sayı 15, ss: 77. Yıldım, A. ve Şimşek, H. (2018). Sosyal Bilimlerde Nitel Araştırma Yöntemleri. Ankara: Seçkin Yayınları.

Yıldız, M. (2011). “Gazali’nin Akı1 Eleştirisi”. TYB Akademi, c: 1; s: 1; Ankara.

Yörünge Dergisi, (1994). Din ve Psikoloji. 27 Mart 1994, sayı 169, ss: 42. 


\section{İnternet Kaynakçaları}

https://evrimagaci.org/icimizdeki-canavar-kahramanlar-evrimsel-psikolojide-carl-gustav-jungunarketipleri-8262

https://katalog.idp.org.tr/dergiler

https://kuranihayat.com/

http://aylikdergisi.com/sayfa-site-hakkimizda-2.html

https://www.yorungedergi.com/.

https://www.sebilurresad.com.tr/index.php?route=information/information\&information_id=1

https://dergipark.org.tr/en/download/article-file/579380

https://twitter.com/zaimuniv/status/1056464643890298880

https://www.malumatfurus.org/zihin-bir-buzdagi-gibidir-sadece-yedide-biri-suyun-uzerindedir/ 